\title{
Pharmacology of Herbal Sexual Enhancers: A Review of Psychiatric and Neurological Adverse Effects
}

\author{
Pietro Brunetti ${ }^{1}$, Alfredo Fabrizio Lo Faro ${ }^{1}$, Anastasio Tini ${ }^{2}$, Francesco Paolo Busardò ${ }^{1 \text {,* }}$ \\ and Jeremy Carlier ${ }^{1,2}$ \\ 1 Unit of Forensic Toxicology, Section of Legal Medicine, Department of Excellence of Biomedical Sciences \\ and Public Health, Marche Polytechnic University, 60126 Ancona, Italy; pietrobrunetti40@gmail.com (P.B.); \\ fabriziolofaro09@gmail.com (A.F.L.F.); jerem.carlier@gmail.com (J.C.) \\ 2 Unit of Forensic Toxicology, Section of Legal Medicine, Department of Anatomical, Histological, Forensic, \\ and Orthopedic Sciences, Sapienza University of Rome, 00198 Rome, Italy; anastasio.tini78@gmail.com \\ * Correspondence: fra.busardo@libero.it; Tel.: +39-071-5964727
}

Received: 9 September 2020; Accepted: 12 October 2020; Published: 14 October 2020

check for updates

\begin{abstract}
Sexual enhancers increase sexual potency, sexual pleasure, or libido. Substances increasing libido alter the concentrations of specific neurotransmitters or sex hormones in the central nervous system. Interestingly, the same pathways are involved in the mechanisms underlying many psychiatric and neurological disorders, and adverse reactions associated with the use of aphrodisiacs are strongly expected. However, sexual enhancers of plant origin have gained popularity over recent years, as natural substances are often regarded as a safer alternative to modern medications and are easily acquired without prescription. We reviewed the psychiatric and neurological adverse effects associated with the consumption of herbal aphrodisiacs Areca catechu L., Argemone Mexicana L., Citrus aurantium L., Eurycoma longifolia Jack., Lepidium meyenii Walp., Mitragyna speciosa Korth., Panax ginseng C. A. Mey, Panax quinquefolius L., Pausinystalia johimbe (K. Schum.) Pierre ex Beille, Piper methysticum G. Forst., Ptychopetalum olacoides Benth., Sceletium tortuosum (L.) N. E. Brown, Turnera diffusa Willd. ex. Schult., Voacanga africana Stapf ex Scott-Elliot, and Withania somnifera (L.) Dunal. A literature search was conducted on the PubMed, Scopus, and Web of Science databases with the aim of identifying all the relevant articles published on the issue up to June 2020. Most of the selected sexual enhancers appeared to be safe at therapeutic doses, although mild to severe adverse effects may occur in cases of overdosing or self-medication with unstandardized products. Drug interactions are more concerning, considering that herbal aphrodisiacs are likely used together with other plant extracts and/or pharmaceuticals. However, few data are available on the side effects of several plants included in this review, and more clinical studies with controlled administrations should be conducted to address this issue.
\end{abstract}

Keywords: aphrodisiac; sexual enhancer; plant; pharmacology; toxicology; psychiatry; neurology; adverse effect

\section{Introduction}

Sexual drive is influenced by biological, psychological, and social factors, but it can also be affected by medications and medical conditions. Many prescription drugs and narcotics (e.g., antidepressants, anxiolytics, antihistamines, antihypertensives, adrenergic receptor blockers, antipsychotics, and opioids) can negatively impact sexual desire, inhibit erection, ejaculation, or orgasm, and so on. Contrariwise, many aphrodisiac substances can improve sexual performance. In particular, substances of natural origin have been used worldwide for millennia in traditional medicines to boost sexual desire, sexual pleasure, or sexual behavior [1], and the use of psychoactive and/or stimulant 
drugs during intercourse, i.e., chemsex, is on the rise [2]. Nowadays, sexual performance anxiety, which contributes to psychogenic erectile dysfunction, is estimated to affect 9 to $25 \%$ of men in the United States, and phytotherapy is often employed as a treatment [3]. In 2007, approximately $56 \%$ of infertile couples had sought medical care worldwide [4] and many of these couples had opted for supportive complementary and alternative medicines to treat infertility. In 2010, in the United States, approximately $29 \%$ of 428 infertile couples had utilized an alternative treatment after 18 months of observation, $59 \%$ of which had taken herbal therapy [5]. Natural substances are mistakenly believed to be a safer alternative to modern medications with no side effects. They are also readily accessible on the Internet and specialized markets without a prescription. Consequently, the use of herbal supplements to enhance sexual drive has become increasingly popular, and more than 300,000 intoxications were reported to poison control centers over the last 20 years [6,7].

According to Sandroni, aphrodisiacs can be classified into three categories according to whether they increase potency (i.e., effectiveness of erection in males), sexual pleasure, or libido (i.e., sexual desire) [8]. Potency-enhancing substances typically induce vasodilation, often through the nitric oxide (NO) pathway, inducing hypotension and potentially harmful cardiovascular effects (e.g., sildenafil and L-arginine). Sexual pleasure-enhancing substances cause tumescence and lubrication of the genital mucosa, therefore increasing sensation (e.g., cantharidin). Libido-enhancing substances alter the concentrations of specific neurotransmitters (e.g., dopaminergic and serotoninergic pathways) or sex hormones (e.g., pituitary hormones and testosterone) in the central nervous system (CNS) [8]. For example, methamphetamine is a synthetic illicit psychomotor stimulant affecting the mesolimbic dopamine pathway, which plays an essential role in motivation and the reward system. A substantial body of evidence shows that acute methamphetamine use is associated with enhanced positive sexual experiences and libido, with a greater likelihood of engaging in high-risk sexual behaviors. Sexual behavior, however, may be impaired due to chronic methamphetamine exposure [9].

The modulation of neurotransmission is also involved in the mechanisms underlying many psychiatric and neurological disorders. For instance, although not fully understood, the dysregulation of monoaminergic systems, especially the decrease in serotoninergic, dopaminergic, and adrenergic neurotransmissions, seems to be the primary cause of depression [10]. Contrariwise, mania is believed to be the consequence of an excess of the same monoamines in specific regions of the brain [11]. Schizophrenia, however, mainly involves dopaminergic and glutamatergic neurotransmissions [12]. In neurology, a deficit of dopamine due to the death of cells in the substantia nigra is the primary cause of Parkinson's disease, while Alzheimer's disease is due to the degeneration of the hippocampus and the raphe nuclei, affecting the cholinergic pathway [13]. The drugs approved to treat psychiatric and neurological conditions mainly target these neurotransmission pathways.

Considering the mechanism of action of sexual enhancers, psychiatric and neurological adverse effects associated with their consumption are strongly expected. In 2014, Corazza et al. reviewed the psychoactive effects of four popular sexual enhancers [6]. In March 2020, Srivatsav et al. reviewed the efficacy and the safety profile of several common aphrodisiacs used in the treatment of erectile dysfunction, but the study was not exhaustive and psychiatric and neurological adverse effects were not addressed [14]. In this review, we aimed to summarize and interpret the findings of cases and preclinical and clinical studies reporting psychiatric and neurological adverse effects associated with the use of aphrodisiacs of plant origin. A preliminary screening of the literature allowed for the identification of several plants with potential psychiatric or neurological complications, which were therefore included in this review: Areca catechu L., Argemone Mexicana L., Citrus aurantium L., Eurycoma longifolia Jack., Lepidium meyenii Walp., Mitragyna speciosa Korth., Panax ginseng C. A. Mey, Panax quinquefolius L., Pausinystalia johimbe (K. Schum.) Pierre ex Beille, Piper methysticum G. Forst., Ptychopetalum olacoides Benth., Sceletium tortuosum (L.) N. E. Brown, Turnera diffusa Willd. ex. Schult., Voacanga africana Stapf ex Scott-Elliot, and Withania somnifera (L.) Dunal. 


\section{Results}

Of 5255 potentially relevant reports, 4758 were excluded because they did not describe psychiatric or neurological adverse effects or because they were not written in English, French, or Italian language. No relevant reports were found for A. Mexicana, E. longifolia, L. meyenii, T. diffusa, V. africana, and $W$. somnifera, which were therefore excluded from the results. A total of 137 records were included in the final review; species-by-species search results are detailed in a flow diagram in Figure 1. A general description of each species including their traditional and modern uses, active ingredients with their mechanism of action and pharmacokinetics, and general toxicity, is provided in the discussion. Psychiatric and neurological adverse events reported in the literature are displayed in Table 1; study conditions and co-exposures are also detailed.

$\begin{array}{ccc}\text { Identification } & \text { Eligibility: } & \text { Included: } \\ \text { and screening: } & \text { Records selected } & \text { Records } \\ \text { Records screened } & \text { for full-text review } & \text { included } \\ \text { (title and abstract) } & & \end{array}$

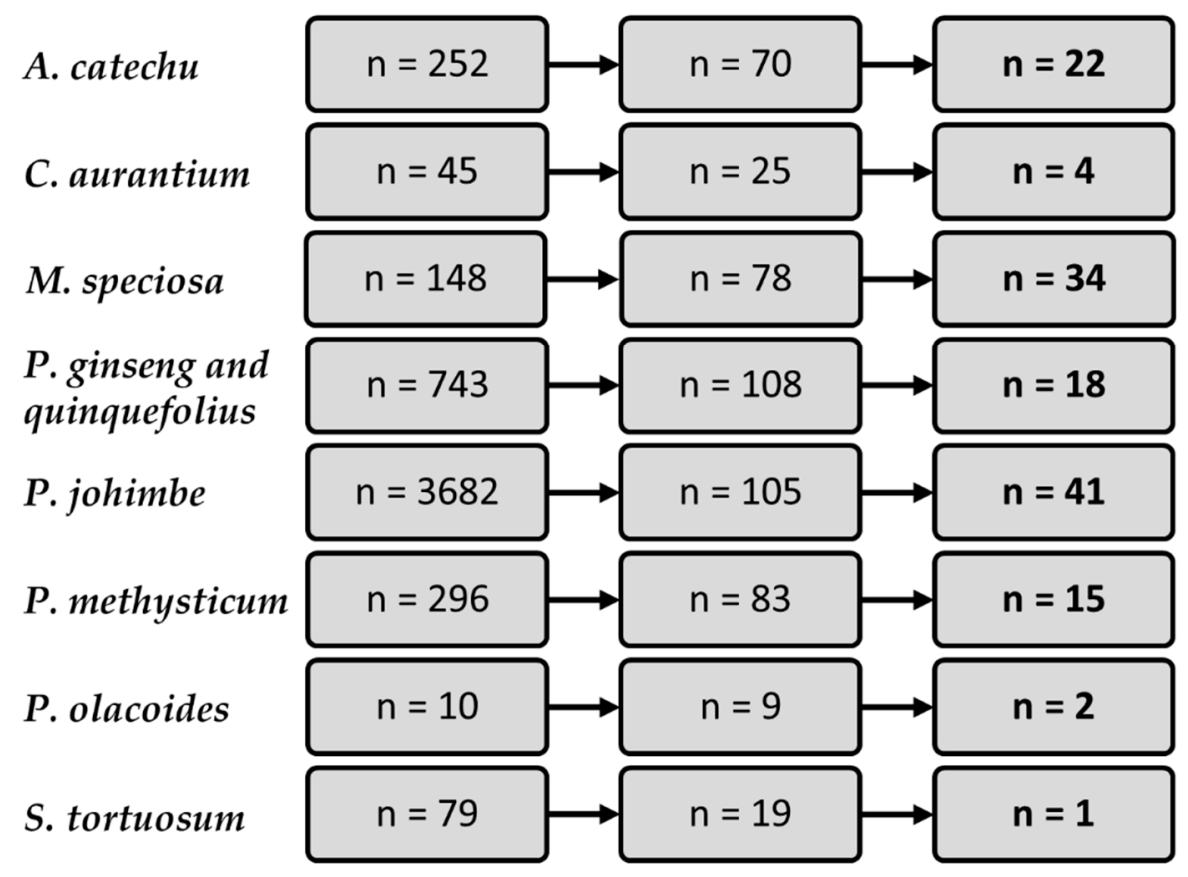

Figure 1. Species-by-species flow diagram of literature search. 
Table 1. Reports of psychiatric and neurological adverse events associated with herbal aphrodisiacs.

\begin{tabular}{|c|c|c|c|c|}
\hline $\begin{array}{l}\text { Plant/Active } \\
\text { Ingredients }\end{array}$ & Co-Exposure & Study, Participants, Age, and Sex & Neurological/Psychiatric Effects & References \\
\hline \multirow{8}{*}{ Areca catechu L. } & $\begin{array}{l}\text { Fluphenazine decanoate, } \\
\text { procyclidine, flupentixol }\end{array}$ & $\begin{array}{l}\text { Case reports of acute intoxications with } \\
\text { Areca catechu L. in two schizophrenic men } \\
\text { aged } 51 \text { and } 45 \text {; both patients consumed a } \\
\text { high quantity of betel nuts for } 2 \text { weeks }\end{array}$ & $\begin{array}{l}\text { Rigidity, bradykinesia, akathisia, } \\
\text { and tremors }\end{array}$ & [15] \\
\hline & $\begin{array}{l}\text { Tobacco, alcohol, } \\
\text { cannabis, amphetamine }\end{array}$ & $\begin{array}{l}\text { Survey study on } 11 \text { participants aged 27-70 } \\
\text { (average = 52), } 9 \text { males and } 2 \text { females; } \\
\text { chewed } 6 \text { nuts/week (range = 4-6 days) }\end{array}$ & $\begin{array}{l}\text { Mood swings, anxiety, irritability, } \\
\text { reduced concentration, reduced } \\
\text { energy, sleep disturbance, craving, } \\
\text { tolerance, and dependence }\end{array}$ & [16] \\
\hline & Tobacco, salbutamol, tea, coffee, arsenic & $\begin{array}{c}\text { Longitudinal pilot study on } \\
100 \text { participants, } 26 \text { users with a mean } \\
( \pm \text { SD) age of } 40.0( \pm 9) \text { years, } 11 \text { males and } \\
15 \text { women }\end{array}$ & Enhancement of physiological tremor & [17] \\
\hline & Tobacco, alcohol & $\begin{array}{l}\text { Cross-sectional study on } 310 \text { pregnant } \\
\text { women, } 292 \text { users, mean age of } 26 \text { years } \\
\text { (range }=25-27) \text {; took } 5-10 \text { nuts } \\
\text { during pregnancy }\end{array}$ & Addiction & [18] \\
\hline & Tobacco & $\begin{array}{l}\text { Survey study on } 59 \text { participants, } 47 \text { males } \\
\text { and } 12 \text { females, median age of } 43.0 \text { years } \\
\text { (range }=12-70) ; 1-50 \text { years of chewing }\end{array}$ & Craving and dependence & [19] \\
\hline & Tobacco & $\begin{array}{c}\text { Cross-sectional study on } 851 \text { participants, } \\
\text { aged } 16-35,314 \text { users, } 242 \text { tobacco }+ \text { users, } \\
\text { and } 295 \text { regular cigarette smokers; }<6->10 \\
\text { years of chewing }\end{array}$ & Tolerance and withdrawal & [20] \\
\hline & Tobacco, alcohol & $\begin{array}{c}\text { Intercountry Asian BQ Consortium study } \\
\text { on } 2078 \text { participants who took any } A \text {. } \\
\text { catechu products/day for a minimum of } \\
6 \text { months }\end{array}$ & $\begin{array}{l}\text { Tolerance, withdrawal, craving, } \\
\text { and dependence syndrome }\end{array}$ & [21] \\
\hline & Tobacco, alcohol & $\begin{array}{c}\text { Survey study on } 41 \text { participants with a } \\
\text { mean }( \pm \mathrm{SD}) \text { age of } 40.34( \pm 9.23) \text { years, } \\
27 \text { males and } 14 \text { females; took } 5 \text { to more } \\
\text { than } 31 \mathrm{BQ} \text { /day }\end{array}$ & $\begin{array}{l}\text { Relaxation, stimulation, addiction, } \\
\text { and withdrawal symptoms }\end{array}$ & [22] \\
\hline
\end{tabular}


Table 1. Cont

\begin{tabular}{|c|c|c|c|c|}
\hline $\begin{array}{l}\text { Plant/Active } \\
\text { Ingredients }\end{array}$ & Co-Exposure & Study, Participants, Age, and Sex & Neurological/Psychiatric Effects & References \\
\hline & $\begin{array}{l}\text { Benzodiazepines, carbamazepine, } \\
\text { levetiracetam, phenobarbital, } \\
\text { phenytoin, sodium valproate, other } \\
\text { medications (not specified) }\end{array}$ & $\begin{array}{c}\text { Observational study on } 152 \text { participants } \\
\text { with epilepsy, } 50 \text { users with a mean age of } \\
28.4 \text { ( } 95 \% \text { CI: } 25.3,31.6 \text { ) years, } 23 \text { males and } \\
27 \text { women; chewed } 1-20 \text { nuts/day for more } \\
\text { than } 5 \text { years }\end{array}$ & Drowsiness & [23] \\
\hline & Tobacco and alcohol- & $\begin{array}{c}\text { Epidemiological studies of dependence on } \\
4031 \text { participants } \\
\text { Case report of two women }\end{array}$ & $\begin{array}{l}\text { Dependence, tolerance, withdrawal, } \\
\text { attentional bias, impaired work, } \\
\text { impaired time perception, } \\
\text { and increased arousal } \\
\text { Poor concentration, lethargy, } \\
\text { despondency, and episodes of } \\
\text { paranoia (1 individual) }\end{array}$ & [24] \\
\hline & Tobacco & $\begin{array}{c}\text { Survey study on } 200 \text { participants, } \\
171 \text { males and } 29 \text { females aged } 22-45 \text { years; } \\
\text { chewed } 4.3 \text { nuts/day }\end{array}$ & Addiction & [25] \\
\hline & $\begin{array}{l}\text { Nicotine, arecaidine }(1.46 \mu \mathrm{g} / \mathrm{mL} \text { in } \\
\text { urine), } \mathrm{N} \text {-methylnipecotate, cotinine }\end{array}$ & $\begin{array}{l}\text { Cross-sectional survey on } 113 \text { participants } \\
\text { with a mean }( \pm \text { SD) age of } 40.0( \pm 12.6) \text { years, } \\
104 \text { males and } 9 \text { females }\end{array}$ & $\begin{array}{l}\text { Craving for } \mathrm{BQ} \text {, addiction, } \\
\text { depression, and drowsiness }\end{array}$ & [26] \\
\hline \multirow[t]{2}{*}{ Arecoline } & Methscopolamine & $\begin{array}{l}\text { Cholinergic REM induction test on } \\
34 \text { participants: } 14 \text { bipolar patients with a } \\
\text { mean }( \pm \text { SD) age of } 30( \pm 6.1) \text { years, } 6 \text { males } \\
\text { and } 8 \text { females; } 15 \text { HC volunteers with a } \\
\text { mean }( \pm \text { SD) age of } 26.8( \pm 4.4) \text { years, } \\
8 \text { males and } 7 \text { females; and } 5 \text { subjects with } \\
\text { a personal or family history of affective } \\
\text { disorders, age ranged between } 23 \text { and } \\
35 \text { years, } 2 \text { males and } 3 \text { females; } \\
\text { administered with } 0.5 \text { mg of arecoline }\end{array}$ & $\begin{array}{l}\text { Shorter REM latency in patients with } \\
\text { primary affective disorders (1st } \\
\text { and 3rd) }\end{array}$ & [27] \\
\hline & Glycopyrrolate & $\begin{array}{l}\text { Pilot dose-response study on } \\
24 \text { participants, } 8 \text { bipolar subjects and } 16 \\
\text { HC monozygotic twins; administered with } \\
1 \text { or } 12 \mathrm{mg} \text { of arecoline IP and } 4 \text { or } 12 \mathrm{mg} \mathrm{SC}\end{array}$ & $\begin{array}{l}\text { Nausea, vomiting, increased anger, } \\
\text { confusion, depression, fatigue and } \\
\text { tension, decreased elation, } \\
\text { friendliness, and vigor }\end{array}$ & [28] \\
\hline
\end{tabular}


Table 1. Cont

\begin{tabular}{|c|c|c|c|c|}
\hline $\begin{array}{l}\text { Plant/Active } \\
\text { Ingredients }\end{array}$ & Co-Exposure & Study, Participants, Age, and Sex & Neurological/Psychiatric Effects & References \\
\hline & Glycopyrrolate & $\begin{array}{c}\text { Arecoline REM induction test on } \\
97 \text { participants: } 20 \text { MDD patients with a } \\
\text { mean age of } 46.6 \text { years (range } 22-83 \text { ), } \\
8 \text { males and } 12 \text { females; } 19 \text { MDD+ANX } \\
\text { patients with a mean age of } 40.0 \text { years } \\
\text { (range } 21-47), 7 \text { males and } 12 \text { females; } 18 \\
\text { ANX patients with a mean age of } 32.2 \text { years } \\
\text { (range 22-51), } 8 \text { males and } 10 \text { females; } \\
14 \text { ANX+MDD patients with a mean age of } \\
32.8 \text { years (range } 23-38 \text { ), } 4 \text { males and } \\
10 \text { females; and } 26 \text { healthy controls with a } \\
\text { mean age of } 36.4 \text { years (range } 20-87 \text { ), } \\
11 \text { males and } 15 \text { females; administered with } \\
0.5 \text { mg of arecoline }\end{array}$ & $\begin{array}{l}\text { Rapid REM induction in MDD and } \\
\text { MDD+ANX patients compared to } \\
\text { healthy controls }\end{array}$ & [29] \\
\hline & Methyl atropine & $\begin{array}{l}\text { Animal study on } 265 \text { Sprague Dawley rats; } \\
\text { administered with } 2 \mathrm{mg} / \mathrm{kg} \text { of arecoline }\end{array}$ & Decreased locomotory activity & [30] \\
\hline & Glycopyrrolate & $\begin{array}{l}\text { Cognitive and behavioral study on } \\
12 \text { participants with AD, mean age of } \\
65.5 \text { years (range } 54-79 \text { ), } 4 \text { males and } \\
8 \text { females; administered with } 0.5 \text { and } \\
12 \mathrm{mg} / \mathrm{h} \text { of arecoline for } 1 \text { to } 6 \mathrm{~h}\end{array}$ & $\begin{array}{l}\text { Decreased knowledge memory, } \\
\text { psychomotor retardation, dysphoria, } \\
\text { and difficulty with verbal expression }\end{array}$ & [31] \\
\hline & Glycopyrrolate & $\begin{array}{c}\text { Arecoline REM induction test on } \\
30 \text { participants: } 10 \text { with atypical depression } \\
\text { with a mean }( \pm \text { SD) age of } 33.5( \pm 7.8) \text { years, } \\
4 \text { males and } 6 \text { females, and } 20 \text { HC with a } \\
\text { mean }( \pm S D) \text { age of } 34.5( \pm 13.8) \text { years, } \\
10 \text { males and } 10 \text { females; administered with } \\
0.5 \mathrm{mg} \text { of arecoline }\end{array}$ & $\begin{array}{c}\text { Rapid REM induction in atypical } \\
\text { depressives without a history of panic } \\
\text { attacks or anxiety disorders } \\
\text { compared to HC }\end{array}$ & [32] \\
\hline
\end{tabular}


Table 1. Cont

\begin{tabular}{|c|c|c|c|c|}
\hline $\begin{array}{l}\text { Plant/Active } \\
\text { Ingredients }\end{array}$ & Co-Exposure & Study, Participants, Age, and Sex & Neurological/Psychiatric Effects & References \\
\hline & Glycopyrrolate & $\begin{array}{l}\text { Catecholamine and ACTH responses to an } \\
\text { arecoline study on } 31 \text { participants: } 15 \text { MSA } \\
\text { patients with a mean }( \pm \text { SD) age of } \\
57.9( \pm 1.8) \text { years, } 8 \text { males and } 7 \text { females; } \\
6 \text { PAF patients with a mean }( \pm \text { SD) age of } \\
52.3( \pm 1.8) \text { years, } 2 \text { males and } 4 \text { females; } \\
\text { and } 10 \text { HC with a mean }( \pm \text { SD) age of } 58.5 \\
( \pm 4) \text { years, } 7 \text { males and } 3 \text { females; } \\
\text { administered with } 0.3 \mathrm{mg} \text { of arecoline }\end{array}$ & $\begin{array}{c}\text { Mild vertigo, nystagmus, nausea, } \\
\text { exacerbation of tremor, and alteration } \\
\text { in mood }\end{array}$ & {$[33]$} \\
\hline & Glycopyrrolate & $\begin{array}{c}\text { Randomized, double-blind, } \\
\text { placebo-controlled study on } 111 \text { participants: } \\
40 \text { placebo-receiving subjects, including } \\
20 \text { depressed patients with a mean }( \pm \text { SD) age } \\
\text { of } 39( \pm 12) \text { years and } 20 \mathrm{HC} \text { with a mean } \\
( \pm \text { SD) age of } 28( \pm 6) \text { years; } 38 \text { subjects } \\
\text { receiving } 0.5 \text { mg of arecoline, including } 21 \\
\text { depressed patients with a mean }( \pm \text { SD) age of } \\
38( \pm 9) \text { years and } 17 \mathrm{HC} \text { with a mean }( \pm \text { SD) } \\
\text { age of } 28( \pm 6) \text { years; and } 33 \text { subjects receiving } \\
1.0 \mathrm{mg} \text { of arecoline, including } 18 \text { depressed } \\
\text { patients with a mean }( \pm \text { SD) age of } 42( \pm 11) \\
\text { years and } 15 \mathrm{HC} \text { with a mean }( \pm \text { SD) age of } \\
34.5( \pm 13.8) \text { years }\end{array}$ & $\begin{array}{l}\text { Shorter REM latency in } \\
\text { depressed patients }\end{array}$ & [34] \\
\hline & - & $\begin{array}{c}\text { Cholinergic REM induction test on } \\
48 \text { participants: } 33 \mathrm{MDD} \text { children with a } \\
\text { mean }( \pm \mathrm{SD}) \text { age of } 10.5( \pm 1.5) \text { years, } 26 \text { males } \\
\text { and } 7 \text { females and } 15 \mathrm{HC} \text { children with a } \\
\text { mean }( \pm \mathrm{SD}) \text { age of } 10.2( \pm 1.6) \text { years; } \\
\text { administered with } 0.5 \mathrm{mg} \text { of arecoline over } \\
60 \mathrm{~min}\end{array}$ & $\begin{array}{l}\text { Shorter REM latency in } \\
\text { depressed children }\end{array}$ & [35] \\
\hline & - & $\begin{array}{l}\text { Animal study on } 63 \text { male albino } \\
\text { Wistar-derived rats; administered with } 0.5 \text {, } \\
1.5 \text {, or } 3.5 \mathrm{mg} / \mathrm{kg} \text { of arecoline SC before test }\end{array}$ & $\begin{array}{l}\text { Accelerated decay of memory after } \\
\text { chronic administration }\end{array}$ & [36] \\
\hline
\end{tabular}


Table 1. Cont

\begin{tabular}{|c|c|c|c|c|}
\hline $\begin{array}{l}\text { Plant/Active } \\
\text { Ingredients }\end{array}$ & Co-Exposure & Study, Participants, Age, and Sex & Neurological/Psychiatric Effects & References \\
\hline & - & $\begin{array}{l}\text { Animal study on } 96 \text { female Sprague } \\
\text { Dawley rats; administered with } 40 \text { or } 80 \mu \mathrm{g} \\
\text { of arecoline }\end{array}$ & Decreased locomotory activity & [37] \\
\hline \multirow{4}{*}{ Citrus aurantium $\mathrm{L}$. } & $\begin{array}{l}\text { Chlordiazepoxide, valproic acid, } \\
\text { diazepam, sodium } \\
\text { pentobarbital, } d \text {-limonene }\end{array}$ & $\begin{array}{l}\text { Animal study on } 176 \text { adult male Swiss mice; } \\
\text { administered with } 0.5 \text { or } 1.0 \mathrm{mg} / \mathrm{kg} \text { of EO } \\
\text { (90.4\% of } d \text {-limonene) and } 1.0 \mathrm{mg} / \mathrm{kg} \text { of four } \\
\text { different fractions of leaves extract orally }\end{array}$ & $\begin{array}{l}\text { Increased hypnotic effect and } \\
\text { enhanced sleeping time induced } \\
\text { by pentobarbital }\end{array}$ & [38] \\
\hline & - & $\begin{array}{c}\text { Randomized, triple-blind, clinical study on } \\
156 \text { postmenopausal women: } \\
52 \text { CA-receiving women with a mean }( \pm \mathrm{SD}) \\
\text { age of } 53.65( \pm 3.55) \text { years, } \\
52 \text { lavender-receiving women with a mean } \\
( \pm \mathrm{SD}) \text { age of } 54.21( \pm 3.86) \text { years, } \\
\text { and } 52 \text { placebo-receiving women with a } \\
\text { mean }( \pm \text { SD) age of } 52.12( \pm 3.49) \text { years; } \\
\text { took } 2 \times 500 \text { mg/day of CA powder for } \\
6 \text { weeks }\end{array}$ & Headache, nausea, and hypnosis & [39] \\
\hline & - & $\begin{array}{c}\text { Randomized, triple-blind, clinical study on } \\
156 \text { postmenopausal women: } \\
52 \text { CA-receiving women with a mean }( \pm \mathrm{SD}) \\
\text { age of } 53.65( \pm 3.55) \text { years, } \\
52 \text { lavender-receiving women with a mean } \\
( \pm \text { SD) age of } 54.21( \pm 3.86) \text { years, } \\
\text { and } 52 \text { placebo-receiving women with a } \\
\text { mean }( \pm \text { SD) age of } 52.12( \pm 3.49) \text { years; } \\
\text { took } 2 \times 500 \text { mg/day of CA powder for } \\
6 \text { weeks }\end{array}$ & Headache and nausea & [40] \\
\hline & Rosa damascena Mill. & $\begin{array}{l}\text { Randomized, double-blind clinical study } \\
\text { on } 99 \text { female students with a mean }( \pm \mathrm{SD}) \\
\text { age of } 22.33( \pm 2.38) \text { years, equally parted } \\
\text { into two intervention groups and a control } \\
\text { group; inhaled EO of CA blossom at } 0.5 \%\end{array}$ & Headache, nausea, and vomiting & [41] \\
\hline
\end{tabular}


Table 1. Cont

\begin{tabular}{|c|c|c|c|c|}
\hline $\begin{array}{l}\text { Plant/Active } \\
\text { Ingredients }\end{array}$ & Co-Exposure & Study, Participants, Age, and Sex & Neurological/Psychiatric Effects & References \\
\hline \multirow{6}{*}{$\begin{array}{l}\text { Mitragyna speciosa } \\
\text { Korth. }\end{array}$} & - & $\begin{array}{l}\text { Cross-sectional study on } 433 \text { participants } \\
\text { with a mean }( \pm \text { SD) age of } 45.7 \text { ( } \pm 13.6) \text { years, } \\
350 \text { males and } 83 \text { females; } 149 \text { regular users } \\
\text { chewed } 12 \text { leaves/day, } 168 \text { occasional users } \\
\text { chewed } 4 \text { leaves/day, and } 116 \text { controls }\end{array}$ & $\begin{array}{l}\text { Dizziness, freshness, sprightliness, } \\
\text { fatigue, shaking hands, headaches, } \\
\text { decreased sexual drive, } \\
\text { poor concentration, distractedness, } \\
\text { difficulty sleeping, irritability, } \\
\text { poor thinking ability, impaired memory, } \\
\text { laziness, and social withdrawal }\end{array}$ & [42] \\
\hline & Modafinil & $\begin{array}{l}\text { Case report of a kratom intoxication of a } \\
43 \text {-year-old male with chronic pain and } \\
\text { opioid withdrawal; took kratom tea four } \\
\text { times daily for } 3.5 \text { years }\end{array}$ & $\begin{array}{l}\text { Withdrawal, drowsiness, } \\
\text { and generalized tonic-clonic seizure }\end{array}$ & [43] \\
\hline & $\begin{array}{l}\text { Datura stramonium L., cannabinoids, } \\
\text { tricyclic antidepressants, oxycodone }\end{array}$ & $\begin{array}{l}\text { Case report of a kratom intoxication of a } \\
\text { 64-year-old male, found with } \\
167 \pm 15 \mathrm{ng} / \mathrm{mL} \text { of mitragynine in urine }\end{array}$ & Seizures and coma & [44] \\
\hline & $\begin{array}{l}\text { heroin, cannabis, amphetamine, } \\
\text { methamphetamine, mitragynine } \\
\qquad(67.5-75 \mathrm{mg} / \text { day })\end{array}$ & $\begin{array}{c}\text { Cross-sectional survey on } 136 \text { participants: } \\
72 \text { short-term users and } 64 \text { long-term users, } \\
\text { age range }=36-65 \text { years, } 135 \text { males and } \\
1 \text { female; took } 3 \times 250 \mathrm{~mL} / \text { day of kratom } \\
\text { tea for } 3.5 \text { years }\end{array}$ & $\begin{array}{l}\text { Loss of weight, tiredness, } \\
\text { dose-dependent stimulation/sedation, } \\
\text { intense craving, withdrawal, chronic } \\
\text { fatigue, insomnia, frequent sweating, } \\
\text { and sudden nerve pain }\end{array}$ & [45] \\
\hline & - & $\begin{array}{l}\text { Case report of a } 44 \text {-year-old kratom } \\
\text { addicted male with a previous history of } \\
\text { alcohol and cocaine dependence; took from } \\
2 \times 4 \mathrm{~g} / \text { day to } 4 \times 10 \mathrm{~g} / \text { day for } 3 \text { years }\end{array}$ & $\begin{array}{l}\text { Wellbeing, euphoria, increased } \\
\text { productivity, industriousness, } \\
\text { relaxation, tolerance, withdrawal } \\
\text { symptoms of cravings, anxiety, } \\
\text { restlessness, and itch }\end{array}$ & [46] \\
\hline & - & $\begin{array}{l}\text { Cross-sectional study on } 530 \text { MS users, } \\
528 \text { males and } 2 \text { females (age not reported); } \\
\text { took MS tea } 1-10 \text { times daily for } 4-5 \text { years }\end{array}$ & $\begin{array}{l}\text { Increased alertness, dizziness, sedation, } \\
\text { hot sensation, hallucination, vomiting, } \\
\text { hostility, aggression, excessive tearing, } \\
\text { inability to work, aching of muscles } \\
\text { and bones, jerky movement of limbs, } \\
\text { loss of appetite, weight loss, insomnia, } \\
\text { malaise, and restlessness }\end{array}$ & {$[47]$} \\
\hline
\end{tabular}


Table 1. Cont

\begin{tabular}{|c|c|c|c|c|}
\hline $\begin{array}{l}\text { Plant/Active } \\
\text { Ingredients }\end{array}$ & Co-Exposure & Study, Participants, Age, and Sex & Neurological/Psychiatric Effects & References \\
\hline & $\begin{array}{l}\text { Amphetamine, haloperidol, } \\
\text { diphenhydramine, } \\
\text { codeine, depressants, unknown } \\
\text { chemical substance }\end{array}$ & $\begin{array}{c}\text { Retrospective study on } 52 \text { participants with } \\
\text { a median age of } 30.5 \text { years (range: } \\
2 \text { days- } 81 \text { years), } 84.6 \% \text { males and } \\
15.4 \% \text { females }\end{array}$ & $\begin{array}{l}\text { Seizure, nausea, alteration of } \\
\text { consciousness, contraction, confusion, } \\
\text { headache, dizziness, syncope, } \\
\text { myalgia, insomnia, fatigue, loss of } \\
\text { appetite, agitation, tremor, ataxia, } \\
\text { dystonia, and neonatal withdrawal }\end{array}$ & [48] \\
\hline & $\begin{array}{l}\text { Wild dagga, wormwood, alprazolam, } \\
\text { synthetic cannabinoid, synthetic } \\
\text { tryptamine, alcohol, } \\
\text { methamphetamine, risperidone }\end{array}$ & $\begin{array}{l}14 \text { kratom exposures reported to the Texas } \\
\text { Poison Center Network of } 11 \text { males and } \\
3 \text { females aged between } 18 \text { and } 48 \text { years }\end{array}$ & $\begin{array}{l}\text { Agitation, nausea, vomiting, } \\
\text { confusion, tremor, diaphoresis, } \\
\text { drowsiness, hallucinations, mydriasis, } \\
\text { and abdominal pain }\end{array}$ & [49] \\
\hline & Alcohol & $\begin{array}{l}\text { Qualitative study on } 34 \text { male participants: } \\
22 \text { regular users chewed } 10-80 \text { leaves/day } \\
\text { for 3-50 years; } 6 \text { occasional users chewed } \\
1-20 \text { leaves/day for } 1-6 \text { years; } 3 \text { non-users; } \\
\text { and } 3 \text { ex-users }\end{array}$ & $\begin{array}{l}\text { Loss of appetite, craving to eat } \\
\text { kratom, withdrawal, compulsion, } \\
\text { impaired control, preoccupation, } \\
\text { loss of weight, muscle/bone/back/joint } \\
\text { aches, cramps/numbness, anxiety, } \\
\text { depressed mood, dysphoria, } \\
\text { moodiness, annoyance, restlessness, } \\
\text { irritability, autonomic nervous system } \\
\text { hyper/hypoactivity, chills, sneeze, } \\
\text { cough, illness/catch cold, sleepy, } \\
\text { yawning, watering eyes, runny nose, } \\
\text { sticky mouth, disturbances of } \\
\text { behaviors and cognitive functions, } \\
\text { and fatigue }\end{array}$ & [50] \\
\hline & Mitragynine (291.9 mg/day) & $\begin{array}{c}\text { Cross-sectional survey on } 293 \text { male kratom } \\
\text { users with a mean age of } 28.9 \text { years, } \\
153 \text { medium-term users and } 140 \text { long-term } \\
\text { users; up to } \geq 3 \times 350 \mathrm{~mL} / \text { day of kratom } \\
\text { fresh juice }\end{array}$ & $\begin{array}{c}\text { Sleeping difficulty, decreased } \\
\text { appetite, nausea, vomiting, muscle } \\
\text { spasm, sweating, fever, abdominal } \\
\text { pain, headaches, hot flashes, hiccups, } \\
\text { shakiness or tremors, severe muscle } \\
\text { pain and cramps, nervousness, } \\
\text { sadness, restlessness, anger, tension, } \\
\text { depressed mood, and craving }\end{array}$ & [51] \\
\hline
\end{tabular}


Table 1. Cont.

\begin{tabular}{|c|c|c|c|c|}
\hline $\begin{array}{l}\text { Plant/Active } \\
\text { Ingredients }\end{array}$ & Co-Exposure & Study, Participants, Age, and Sex & Neurological/Psychiatric Effects & References \\
\hline & - & $\begin{array}{c}\text { Qualitative study on } 168 \text { kratom users: } \\
109 \text { males, } 13 \text { females, and } 44 \text { others (sex } \\
\text { not specified) }\end{array}$ & $\begin{array}{c}\text { Warmth/tingling, } \\
\text { nausea/stomachache, alternating } \\
\text { chills/sweats, dizziness/unsteadiness, } \\
\text { vomiting, itching, numbness in } \\
\text { mouth/throat, visual alterations, } \\
\text { and sedation }\end{array}$ & [52] \\
\hline & $\begin{array}{l}\text { Alcohol, other botanicals, } \\
\text { benzodiazepines, narcotics, } \\
\text { acetaminophen }\end{array}$ & $\begin{array}{c}660 \text { calls about kratom exposure received } \\
\text { by U.S. poison centers, the median age was } \\
28 \text { years (range }=2 \text { months- } 69 \text { years, } \\
\text { data available for } 604 \text { subjects), } 472 \text { males } \\
\text { and } 186 \text { females (data available for } \\
658 \text { subjects) }\end{array}$ & $\begin{array}{l}\text { Agitation, irritability, drowsiness, } \\
\text { and nausea }\end{array}$ & {$[53]$} \\
\hline & - & $\begin{array}{c}\text { Cross-sectional study on } 526 \text { kratom users } \\
\text { with a mean age of } 51.8 \text { years; } \\
\text { took 3-17 leaves/day }\end{array}$ & $\begin{array}{l}\text { Craving-fatigue syndrome, } \\
\text { mood symptoms, insomnia, } \\
\text { and physical sickness }\end{array}$ & [54] \\
\hline & Tramadol, codeine, morphine & $\begin{array}{c}\text { Case reports of two kratom-addicted } \\
\text { subjects, a } 60 \text {-year-old female who took } \\
0.25 \text { ounces of kratom every } 4 \mathrm{~h} \text { for several } \\
\text { months, and a } 57 \text {-year-old male }\end{array}$ & $\begin{array}{c}\text { Dependence, tolerance, irritability, } \\
\text { increased pain, anxiety, edginess, } \\
\text { and leg shaking }\end{array}$ & [55] \\
\hline & - & $\begin{array}{l}\text { Retrospective study on } 150 \text { male } \\
\text { participants with a mean }( \pm \mathrm{SD}) \text { age of } 34.4 \\
( \pm 11.2) \text { years; took up to } \geq 4 \times 350 \mathrm{~mL} / \text { day } \\
\text { of kratom fresh juice }\end{array}$ & $\begin{array}{l}\text { Withdrawal symptoms, anxiety, } \\
\text { and depression }\end{array}$ & [56] \\
\hline & Morphine & $\begin{array}{l}\text { Case report of a maternal (a 29-year-old } \\
\text { female) and neonatal kratom exposure; } \\
\text { took } 3 \times 18-20 \mathrm{~g} / \text { day of kratom powder }\end{array}$ & $\begin{array}{l}\text { Anxiety and maternal and } \\
\text { neonatal withdrawal }\end{array}$ & [57] \\
\hline & - & $\begin{array}{c}\text { Case report of a female infant's NAS, } \\
\text { her mother took 3-4 kratom teas/day } \\
\text { during her pregnancy }\end{array}$ & $\begin{array}{l}\text { Excessive sucking, irritability, } \\
\text { sleeplessness, and withdrawal }\end{array}$ & [58] \\
\hline
\end{tabular}


Table 1. Cont

\begin{tabular}{|c|c|c|c|c|}
\hline $\begin{array}{l}\text { Plant/Active } \\
\text { Ingredients }\end{array}$ & Co-Exposure & Study, Participants, Age, and Sex & Neurological/Psychiatric Effects & References \\
\hline & - & $\begin{array}{l}\text { Case report of a kratom overdose and } \\
\text { management of withdrawal of a } \\
\text { 24-year-old man with Asperger syndrome, } \\
\text { depression, and long-term substance } \\
\text { dependence; took } 600 \mathrm{mg} / \text { day of kratom }\end{array}$ & $\begin{array}{l}\text { Unresponsiveness, seizures, } \\
\text { and withdrawal }\end{array}$ & [59] \\
\hline & Lisdexamfetamine & $\begin{array}{l}\text { Case report of a kratom intoxication of a } \\
\text { 19-year-old male with ADHD; took several } \\
\text { pills }(2-8 \mathrm{~g}) \text { per day for several months }\end{array}$ & Seizures & {$[60]$} \\
\hline & Benzodiazepines & $\begin{array}{c}\text { Case report of a 52-year-old } \\
\text { kratom-addicted female with a } \\
\text { long-standing history of MDD; took } 1 \\
\text { tablespoon 4-6 times per day for } 9 \text { months }\end{array}$ & $\begin{array}{l}\text { Increased depression, anxiety, } \\
\text { suicidal thoughts, exacerbation of } \\
\text { chronic pain issues, dysphoria, } \\
\text { nausea, muscle aches, sweating, } \\
\text { goose bumps, and insomnia }\end{array}$ & [61] \\
\hline & - & $\begin{array}{l}\text { Cross-sectional study on } 95 \text { male } \\
\text { participants: } 70 \text { kratom users with a mean } \\
( \pm \text { SD) age of } 28.8( \pm 5.3) \text { who took } 3 \text { glasses } \\
\text { of kratom tea/juice daily, and } 25 \text { healthy } \\
\text { controls with a mean }( \pm \text { SD) age of } 25( \pm 7.6)\end{array}$ & $\begin{array}{l}\text { Visual memory and new } \\
\text { learning impairment }\end{array}$ & [62] \\
\hline & - & $\begin{array}{c}\text { Cross-sectional study on } 150 \text { male kratom } \\
\text { users with a mean }( \pm \mathrm{SD}) \text { age of } 34.4( \pm 11.2) \\
\text { years; took up to } \geq 3 \text { glasses/day for more } \\
\text { than } 6 \text { years }\end{array}$ & $\begin{array}{l}\text { Auditory, visual, tactile, and olfactory } \\
\text { hallucinations, persecutory, reference, } \\
\text { control and grandiose delusion } \\
\text { thought broadcasting, } \\
\text { and withdrawal }\end{array}$ & [63] \\
\hline & Alcohol, clonazepam, cocaine & $\begin{array}{l}\text { Brief report on } 2321 \text { kratom exposures, } \\
\text { of which } 4 \text { cases of NAS and } 2 \text { deaths were } \\
\text { reported, and } 4 \text { deaths for which kratom } \\
\text { was listed as a cause or contributing factor } \\
\text { to the death }\end{array}$ & $\begin{array}{l}\text { Agitation, drowsiness, confusion, } \\
\text { seizure, withdrawal, hallucinations, } \\
\text { respiratory depression, coma, } \\
\text { and cardiac or respiratory arrest }\end{array}$ & [64] \\
\hline & Alcohol, other unknown substances & $\begin{array}{l}\text { Case reports of kratom intoxications with } \\
4 \text { males with a mean age of } 43.5 \text { years } \\
\text { (range }=44-67 \text { ); case } 2 \text { took } 4 \times 10 \mathrm{~g} / \text { day of } \\
\text { kratom over } 24 \mathrm{~h}\end{array}$ & $\begin{array}{l}\text { Seizure, sedation, withdrawal } \\
\text { symptoms, } \\
\text { and dependence syndrome }\end{array}$ & [65] \\
\hline
\end{tabular}


Table 1. Cont

\begin{tabular}{|c|c|c|c|c|}
\hline $\begin{array}{l}\text { Plant/Active } \\
\text { Ingredients }\end{array}$ & Co-Exposure & Study, Participants, Age, and Sex & Neurological/Psychiatric Effects & References \\
\hline & Opiate, methamphetamine, methadone & $\begin{array}{l}\text { Cross-sectional survey on } 163 \text { regular } \\
\text { kratom male users with a mean }( \pm \mathrm{SD}) \text { age } \\
\text { of } 37.1( \pm 10.9) \text { years; took } 1-3 \text { glasses/day } \\
\text { of kratom tea for more than } 6 \text { years }\end{array}$ & $\begin{array}{l}\text { Weight loss, physical pain, loss of } \\
\text { appetite, fatigue, craving for opioid, } \\
\text { insomnia, and depression }\end{array}$ & [66] \\
\hline & - & $\begin{array}{l}\text { Case reports of two kratom intoxications: } \\
\text { a } 27 \text {-year-old male with bipolar disorder } \\
\text { and schizophrenia who took } 5 \mathrm{~g} / \text { day of } \\
\text { kratom for } 3 \text { years, and a } 26 \text {-year-old } \\
\text { female with no history of mental health } \\
\text { disorders who took } 2-3 \text { pills/day (20-30 g } \\
\text { of kratom/day) for } 2 \text { years }\end{array}$ & $\begin{array}{l}\text { Restlessness, generalized body aches, } \\
\text { overwhelming anxiety, thoughts of } \\
\text { suicide, hallucinations, } \\
\text { and withdrawal symptoms }\end{array}$ & [67] \\
\hline & Dextroamphetamine & $\begin{array}{l}\text { Case report of a 22-year-old male with } \\
\text { ADHD and kratom use disorder; } \\
\text { took kratom tea every } 2 \mathrm{~h} \text { daily ( } 30 \mathrm{~g} \text { at } \\
\text { maximum dosage) for } 2 \text { years }\end{array}$ & $\begin{array}{l}\text { Tolerance, irritability, } \\
\text { and withdrawal symptoms }\end{array}$ & {$[68]$} \\
\hline & Diphenhydramine & $\begin{array}{l}\text { Case report of a 27-year-old male with a } \\
\text { history of ANX, ADHD, benzodiazepine, } \\
\text { and opioid use disorders; took up to } \\
4 \times 8 \mathrm{~mL} / \text { day bottles of kratom for } 1.5 \text { years }\end{array}$ & Tonic-clonic seizures & [69] \\
\hline & $\begin{array}{c}\text { Alcohol, antidepressants, } \\
\text { benzodiazepines, cannabis, cocaine, } \\
\text { hallucinogens, opioids (prescribed or } \\
\text { illicit), tobacco }\end{array}$ & $\begin{array}{c}\text { Online anonymous cross-sectional survey } \\
\text { on } 2798 \text { kratom users with a mean }( \pm \text { SD) } \\
\text { age of } 40.2( \pm 11.8) \text { years, } 1099 \text { males and } \\
1699 \text { females; took up to } 3 \times 1-6 \mathrm{~g} / \text { day } \\
\text { of kratom }\end{array}$ & $\begin{array}{c}\text { Sickness, dizziness, alertness, anxiety, } \\
\text { sleepiness, } \\
\text { and withdrawal symptoms }\end{array}$ & {$[70]$} \\
\hline & - & $\begin{array}{l}\text { Cross-sectional quantitative study on } 356 \\
\text { participants, } 137 \text { kratom users and } 219 \\
\text { non-users aged between } 18 \text { and } \geq 37 \text { years, } \\
212 \text { males and } 144 \text { females }\end{array}$ & $\begin{array}{l}\text { Addiction, withdrawal symptoms, } \\
\text { and impaired social functioning }\end{array}$ & [71] \\
\hline
\end{tabular}


Table 1. Cont.

\begin{tabular}{|c|c|c|c|c|}
\hline $\begin{array}{c}\text { Plant/Active } \\
\text { Ingredients }\end{array}$ & Co-Exposure & Study, Participants, Age, and Sex & Neurological/Psychiatric Effects & References \\
\hline \multirow{5}{*}{ Mitragynine } & Scopolamine & $\begin{array}{c}\text { Animal study on } 36 \text { male mice from the } \\
\text { ICR strain: } 18 \text { mitragynine-treated mice } \\
\text { administered with } 5,10, \text { or } 15 \mathrm{mg} / \mathrm{kg} \text { IP of } \\
\text { for } 28 \text { days; } 6 \text { scopolamine-treated mice; } \\
\text { and } 12 \mathrm{HC}\end{array}$ & $\begin{array}{l}\text { Impaired working memory function } \\
\text { and reduction in locomotory activity }\end{array}$ & [72] \\
\hline & $\begin{array}{l}\text { 7-hydroxymitragynine }(0.15 \mathrm{mg} / \mathrm{L} \text { in } \\
\text { blood, } 2.20 \mathrm{mg} / \mathrm{L} \text { in urine }), \text { zopiclone, } \\
\text { citalopram, lamotrigine }\end{array}$ & $\begin{array}{l}\text { Fatal mitragynine intoxication of a } \\
\text { middle-aged male, found with } 1.06 \text { and } \\
3.47 \mathrm{mg} / \mathrm{L} \text { of mitragynine in blood and } \\
\text { urine, respectively }\end{array}$ & CNS depression & [73] \\
\hline & Morphine, methamphetamine, & $\begin{array}{c}\text { Animal study on male C57BL/6 mice; } \\
\text { administered with } 1,5,10 \text {, or } 20 \mathrm{mg} / \mathrm{kg} \text { IP } \\
30 \text { min before or immediately after } \\
\text { locomotor and consolidation tests, } \\
30 \mathrm{mg} / \mathrm{kg} \text { IP for } 14 \text { days for the withdrawal } \\
\text { induction and for } 28 \text { days for the } \\
\text { chronic study }\end{array}$ & $\begin{array}{l}\text { Decreased activity in the } \delta, \theta \text {, and } \beta, \\
\text { but not } \alpha \text { band in the hippocampus } \\
\text { and withdrawal }\end{array}$ & {$[74]$} \\
\hline & $\begin{array}{l}\text { Morphine, penicillin G procaine, } \\
\text { propofol, xylazine, ketamine, } \\
\text { naltrindole, naloxonazine }\end{array}$ & $\begin{array}{c}\text { Animal study on } 39 \text { male Fischer } 334 \text { rats; } \\
\text { administered with } 25,50,100 \text {, or } 150 \mu \mathrm{g} \text { of } \\
\text { mitragynine and } 2.5,5,10 \text {, or } 20 \mu \mathrm{g} \text { of } \\
\text { 7-hydroxymitragynine }\end{array}$ & $\begin{array}{c}\text { Increased morphine } \\
\text { self-administration after } \\
\text { 7-hydroxymitragynine treatment }\end{array}$ & [75] \\
\hline & Morphine, urethane, xylocaine & $\begin{array}{l}\text { Animal study on } 60 \text { male Sprague Dawley } \\
\text { rats and other set of animals used for } \\
\text { in vivo electrophysiological studies; } \\
\text { administered with } 1.0,5.0 \text { and } 10.0 \mathrm{mg} / \mathrm{kg} \\
\text { of mitragynine IP }\end{array}$ & $\begin{array}{l}\text { Impaired acquisition of spatial } \\
\text { learning and significant synaptic } \\
\text { depression in the hippocampal region } \\
\text { at high mitragynine doses }\end{array}$ & [76] \\
\hline \multirow{2}{*}{$\begin{array}{l}\text { Panax ginseng C. A. } \\
\text { Mey }\end{array}$} & Fluvoxamine, venlafaxine & $\begin{array}{l}\text { Case report of a } 47 \text {-year-old female with } \\
\text { chronic depression; took } 200 \mathrm{mg} \text { of ginseng } \\
\text { extract within } 24 \mathrm{~h}\end{array}$ & Hypomania & [77] \\
\hline & - & $\begin{array}{l}\text { Case report of a 26-year-old male with } \\
\text { history of suicidal thoughts; } \\
\text { took } 250 \mathrm{mg} / \text { day of Chinese ginseng for } \\
\text { two weeks }\end{array}$ & $\begin{array}{l}\text { Restless, insomnia, } \\
\text { agitation, disorganization }\end{array}$ & [78] \\
\hline
\end{tabular}


Table 1. Cont

\begin{tabular}{|c|c|c|c|c|}
\hline $\begin{array}{l}\text { Plant/Active } \\
\text { Ingredients }\end{array}$ & Co-Exposure & Study, Participants, Age, and Sex & Neurological/Psychiatric Effects & References \\
\hline & Contraceptive pill, ginsenosides ( $4 \%$ ) & $\begin{array}{l}\text { Placebo-controlled, clinical study on } \\
20 \text { participants with (mean }( \pm \text { SD) age of } \\
20.6( \pm 4.2), 10 \text { males and } 10 \text { females; } \\
\text { administered with placebo and } 5 \times 200,400 \text {, } \\
\text { or } 600 \mathrm{mg} \text { of ginseng extract with a } 7 \text {-day } \\
\text { wash-out between administrations }\end{array}$ & Decreased speed attention & [79] \\
\hline & Ginkgo biloba L., contraceptive pill. & $\begin{array}{c}\text { Placebo-controlled, clinical study on } \\
20 \text { participants with a mean }( \pm \text { SD) age of } \\
20.6( \pm 4.2), 10 \text { males and } 10 \text { females; } \\
\text { administered with placebo and } 5 \times 200,400 \text {, } \\
\text { or } 600 \mathrm{mg} \text { of ginseng extract with a } 7 \text {-day } \\
\text { wash-out between administrations }\end{array}$ & Decreased speed attention & [80] \\
\hline & Clomipramine & $\begin{array}{l}\text { Case report of ginseng intoxication of a } \\
\text { MDD 56-year-old woman; took } 300 \mathrm{mg} / \text { day } \\
\text { of root extract for } 2 \text { weeks }\end{array}$ & $\begin{array}{c}\text { Hyperactivity, insomnia, dysphoria, } \\
\text { and verbal and physical } \\
\text { aggressiveness }\end{array}$ & [81] \\
\hline & $\begin{array}{c}\text { Ginkgo biloba } \text { L., vitamins and minerals, } \\
\text { cold-liver oil, primrose oil, } \\
\text { caffeine, alcohol }\end{array}$ & $\begin{array}{c}\text { Randomized, double-blind, } \\
\text { placebo-controlled clinical study on } \\
70 \text { post-menopausal females, } \\
12 \text { ginseng-receiving subjects with a mean } \\
( \pm \text { SD) age of } 58.4( \pm 1.0) \text { years and } \\
14 \text { placebo-receiving subjects with a mean } \\
( \pm \text { SD) age of } 57.4( \pm 0.7) \text { years; } \\
\text { administered with } 2 \times 100 \mathrm{mg} / \text { day of } \\
\text { ginseng extract for } 12 \text { weeks }\end{array}$ & Slight depression (one case) & [82] \\
\hline & Ginsenosides (27-30\%) & $\begin{array}{l}\text { Single-blind, placebo-controlled clinical } \\
\text { study on } 14 \text { - and a } 17 \text {-year-old ADHD } \\
\text { males; administered with } 2 \times 250 \mathrm{mg} / \text { day } \\
\text { of ginseng extract }\end{array}$ & Mild sedation & [83] \\
\hline
\end{tabular}


Table 1. Cont.

\begin{tabular}{|c|c|c|c|c|}
\hline $\begin{array}{l}\text { Plant/Active } \\
\text { Ingredients }\end{array}$ & Co-Exposure & Study, Participants, Age, and Sex & Neurological/Psychiatric Effects & References \\
\hline & $\begin{array}{l}\mathrm{Rg} 1, \mathrm{Rb} 1, \mathrm{Rg} 3, \mathrm{Re}, \mathrm{Rc}, \mathrm{Rb} 2, \mathrm{Rd}, \mathrm{Rf}, \mathrm{Rh} 1, \\
\mathrm{Rg} 2 \mathrm{~s} \text {, other minor ginsenosides, } \\
\text { escitalopram, venlafaxine, paroxetine, } \\
\text { duloxetine, citalopram, bupropion, } \\
\text { fluvoxamine, imipramine, trazodone }\end{array}$ & $\begin{array}{l}\text { Open-label study on } 35 \text { MDD females with a } \\
\text { mean }( \pm \text { SD) age of } 45.1( \pm 9.5) \text { years; } \\
\text { administered with } 2 \mathrm{~g} \text { at day } 1 \text { of red ginseng } \\
\text { extract titrated at } 3 \mathrm{~g} / \text { day for } 4 \text { weeks and } \\
\text { maintained for another } 4 \text { weeks }\end{array}$ & $\begin{array}{l}\text { Headache, insomnia, } \\
\text { and hypersomnia }\end{array}$ & {$[84]$} \\
\hline & Cannabis & $\begin{array}{l}\text { Case reports on two ginseng intoxications of } \\
\text { 23- and a } 79 \text {-years-old; took ginseng } \cong 15 \text { and } \\
\quad \cong 20 \mathrm{~g} / \text { day, respectively }\end{array}$ & $\begin{array}{l}\text { Racing thoughts, anxiety, irritable } \\
\text { mood, labile affect, disorganized } \\
\text { thought process, constant distraction, } \\
\text { and auditory hallucinations, }\end{array}$ & [85] \\
\hline & $\begin{array}{c}\text { Chemotherapies, ginsenosides, } \\
\text { malonylginsenosides }\end{array}$ & $\begin{array}{c}\text { Open-label study on } 30 \text { patients with } \\
\text { cancer-related fatigue and under } \\
\text { chemotherapy with a median age of } 58 \text { (range } \\
=48-68 \text { ) years, } 15 \text { males and } 15 \text { females; } \\
\text { administered with } 2 \times 400 \mathrm{mg} / \text { day ginseng } \\
\text { root extract for } 4 \text { weeks }\end{array}$ & $\begin{array}{l}\text { Pain, nausea, cognitive disturbance, } \\
\text { and seizure }\end{array}$ & [86] \\
\hline & Multivitamins, herbal supplements & $\begin{array}{l}\text { Case report of a } 42 \text {-year-old female with no } \\
\text { history of psychiatric issue or illicit drug use }\end{array}$ & Psychosis and confusion & [87] \\
\hline & - & $\begin{array}{l}\text { Case report of a ginseng intoxication (age, } \\
\text { sex, and dose not specified) }\end{array}$ & Mania & [88] \\
\hline & Methadone & $\begin{array}{l}\text { Randomized, double-blind, } \\
\text { placebo-controlled clinical study on } \\
74 \text { opioid-addicted participants under } \\
\text { methadone maintenance treatment, } 48 \text { males } \\
\text { with a mean age of } 40.64 \text { years and } \\
26 \text { females with a mean age of } 39.0 \text { years; } \\
\text { administered with } 4 \times 250 \text { mg of root powder }\end{array}$ & Sleepiness and agitation & [89] \\
\hline & - & $\begin{array}{l}\text { Case report of a } 47 \text {-year-old male with no } \\
\text { history of psychiatric disorder; took } 600 \\
\text { mg/day ginseng to increase energy and } \\
\text { sexual activity }\end{array}$ & $\begin{array}{l}\text { Nervousness, aggressive behaviors, } \\
\text { irritability, increased psychomotor } \\
\text { activity, decreased sleep, } \\
\text { and excessive talkativeness }\end{array}$ & [90] \\
\hline
\end{tabular}


Table 1. Cont

\begin{tabular}{|c|c|c|c|c|}
\hline $\begin{array}{l}\text { Plant/Active } \\
\text { Ingredients }\end{array}$ & Co-Exposure & Study, Participants, Age, and Sex & Neurological/Psychiatric Effects & References \\
\hline & $\begin{array}{c}\text { Eicosapentaenoic acid, } \\
\text { docosahexaenoic acid, Rg1, Rb1, Rg3 }\end{array}$ & $\begin{array}{l}\text { Open-label study on } 40 \text { ADHD children } \\
\text { with a mean }( \pm \text { SD) age of } 8( \pm 1.45) \text { years } \\
31 \text { males and } 9 \text { females; administered with } \\
3 \mathrm{mg} / \text { day ginseng extract for } 12 \text { weeks }\end{array}$ & Transitory headache (one case) & [91] \\
\hline \multirow{3}{*}{ Panax quinquefolius L. } & $\begin{array}{l}\text { Phenelzine, bee pollen, other } \\
\text { natural medications }\end{array}$ & $\begin{array}{l}\text { Case report of a 42-year-old female with } \\
\text { chronic depression, but no history of } \\
\text { manic episodes }\end{array}$ & Mania and hallucinations & {$[92]$} \\
\hline & Ginkgo biloba L., ritalin, efamol & $\begin{array}{c}\text { Open-label study on } 36 \text { ADHD children } \\
\text { with a mean }( \pm \text { SD) age of } 10.2( \pm 3.7) ; \\
\text { administered with } 2 \times 200 \mathrm{mg} / \text { day of } \\
\text { ginseng extract for } 4 \text { weeks }\end{array}$ & $\begin{array}{l}\text { Increased impulsiveness, } \\
\text { hyperactivity and aggressiveness, } \\
\text { headache, and tiredness }\end{array}$ & [93] \\
\hline & $\begin{array}{l}\text { Tamoxifen, other estrogenic } \\
\text { botanical supplements }\end{array}$ & $\begin{array}{l}\text { Multicenter, prospective study on } 788 \text { with } \\
\text { breast cancer; } 103 \text { used ginseng after } \\
\text { cancer diagnosis }\end{array}$ & Fatigue & [94] \\
\hline \multirow{3}{*}{$\begin{array}{l}\text { Pausinystalia johimbe (K. } \\
\text { Schum.) Pierre ex } \\
\text { Beille (yohimbine) }\end{array}$} & Corynanthine $(5,20 \mathrm{mg} / \mathrm{kg})$ & $\begin{array}{c}\text { Animal study on } 101 \text { male Sprague Dawley } \\
\text { rats; administered with } 5 \text { or } 20 \mathrm{mg} / \mathrm{kg} \text { of } \\
\text { yohimbine IP }\end{array}$ & $\begin{array}{l}\text { Decrease in spontaneous locomotor } \\
\text { activity, overreaction to external } \\
\text { stimuli, violent tremors, convulsions, } \\
\text { abnormal posture, and decrease in } \\
\text { body temperature }\end{array}$ & [95] \\
\hline & $\begin{array}{c}\text { Xylazine, } \\
\text { Doxapram, 4-aminopyridine }\end{array}$ & $\begin{array}{l}\text { Animal study on } 82 \text { red deer (Cervus } \\
\text { elaphus L.), administered with } 0.063,0.124, \\
0.125,0.128,0.189,0.20,0.21,0.23,0.24,0.25 \text {, } \\
\text { or } 1.00 \mathrm{mg} / \mathrm{kg} \text { of yohimbine IV }\end{array}$ & $\begin{array}{l}\text { Rapid reaction to external stimuli, } \\
\text { anxiety, and nervousness }\end{array}$ & [96] \\
\hline & Desipramine, bupropion, trazodone & $\begin{array}{l}\text { Three case reports of manic symptoms } \\
\text { following yohimbine administration of } \\
\text { three psychiatric patients: a } 41 \text {-year-old } \\
\text { male who took } 10 \text { mg of yohimbine orally, } \\
\text { and } 20 \text { - and } 43 \text {-year-old females who took } \\
20 \text { mg of yohimbine in two sessions and } \\
\text { one session, respectively }\end{array}$ & $\begin{array}{l}\text { Tremors, nausea, generalized } \\
\text { restlessness, diaphoresis, } \\
\text { and palpitations }\end{array}$ & {$[97]$} \\
\hline
\end{tabular}


Table 1. Cont

\begin{tabular}{|c|c|c|c|c|}
\hline $\begin{array}{l}\text { Plant/Active } \\
\text { Ingredients }\end{array}$ & Co-Exposure & Study, Participants, Age, and Sex & Neurological/Psychiatric Effects & References \\
\hline & - & $\begin{array}{c}\text { Randomized, double-blind, } \\
\text { placebo-controlled study on } 59 \text { participants: } \\
39 \text { drug-free patients with agoraphobia and } \\
\text { panic attacks-11 males with a mean }( \pm \text { SD) } \\
\text { age of } 36.8( \pm 8.2) \text { years and } 29 \text { females with } \\
\text { a mean }( \pm S D) \text { age of } 38.8( \pm 10.1) \text { years; } \\
\text { and } 20 \mathrm{HC}-9 \text { males with a mean }( \pm S D) \\
\text { age of } 33.3( \pm 7.3) \text { years and } 11 \text { females with } \\
\text { a mean }( \pm S D) \text { age of } 43.3( \pm 7.4) \text { years; } \\
\text { administered with } 4 \times 5 \text { mg of } \\
\text { yohimbine capsules }\end{array}$ & $\begin{array}{l}\text { Anxiety, nervousness, hot and cold } \\
\text { flashes, restlessness, tremors, } \\
\text { and piloerection }\end{array}$ & [98] \\
\hline & Acetylsalicylic acid & $\begin{array}{l}\text { Case report of an acute yohimbine } \\
\text { intoxication of a 16-year-old female; } \\
\text { took } 250 \mathrm{mg} \text { of powdered yohimbine }\end{array}$ & $\begin{array}{l}\text { Weakness, generalized paresthesia, } \\
\text { loss of coordination, dissociative } \\
\text { state, severe headache, dizziness, } \\
\text { tremors, decreased hearing, nausea, } \\
\text { diaphoresis, } \\
\text { and intermittent palpitations }\end{array}$ & [99] \\
\hline & - & $\begin{array}{c}\text { Randomized, double-blind, } \\
\text { placebo-controlled study on } 88 \text { participants: } \\
68 \text { agoraphobic subjects with panic attacks } \\
\text { or panic disorder }-19 \text { males with a mean } \\
( \pm \text { SD) age of } 38( \pm 9) \text { years and } 49 \text { females } \\
\text { with a mean }( \pm \text { SD) age of } 40( \pm 1) \text { years; } \\
\text { and } 20 \mathrm{HC}-9 \text { males with a mean }( \pm \text { SD) } \\
\text { age of } 34( \pm 8) \text { years and } 11 \text { females with a } \\
\text { mean }( \pm \text { SD) age of } 43( \pm 7) \text { years; } \\
\text { administered with } 4 \times 5 \text { mg of } \\
\text { yohimbine capsules }\end{array}$ & $\begin{array}{l}\text { Increased rate of panic } \\
\text { attacks, anxiety }\end{array}$ & [100] \\
\hline & - & $\begin{array}{l}\text { Animal study on male hooded Lister rats; } \\
\text { administered with } 2.5 \text { or } 5 \mathrm{mg} / \mathrm{kg} \text { of } \\
\text { yohimbine IP for acute exposure evaluation } \\
\text { and } 2.5 \mathrm{or} 5 \mathrm{mg} / \mathrm{kg} \text { daily for } 5 \text { days for } \\
\text { chronic exposure evaluation }\end{array}$ & $\begin{array}{l}\text { Decreased locomotory activity and } \\
\text { increased anxiety }\end{array}$ & [101] \\
\hline
\end{tabular}


Table 1. Cont.

\begin{tabular}{|c|c|c|c|c|}
\hline $\begin{array}{l}\text { Plant/Active } \\
\text { Ingredients }\end{array}$ & Co-Exposure & Study, Participants, Age, and Sex & Neurological/Psychiatric Effects & References \\
\hline & - & $\begin{array}{c}\text { Randomized, double-blind, } \\
\text { placebo-controlled study on } 65 \text { participants: } \\
45 \text { depressed subjects with a mean }( \pm \mathrm{SD}) \\
\text { age of } 41( \pm 13) \text { years }-17 \text { males and } \\
28 \text { females; and } 20 \mathrm{HC} \text { with a mean }( \pm \mathrm{SD}) \\
\text { age of } 39( \pm 9) \text { years }-9 \text { males and } \\
11 \text { females; administered with } 4 \times 5 \mathrm{mg} \text { of } \\
\text { yohimbine capsules }\end{array}$ & $\begin{array}{l}\text { Drowsiness, nervousness, anxiety, } \\
\text { fear, sadness, depression, nausea, } \\
\text { tremors, hot and cold flashes, } \\
\text { and muscle aches }\end{array}$ & [102] \\
\hline & Amitriptyline & $\begin{array}{l}\text { Animal study on } 12 \text { male Sprague Dawley } \\
\text { rats; administered with } 5 \mathrm{mg} / \mathrm{kg} \text { IP weekly } \\
\text { for } 6 \text { weeks }\end{array}$ & Profound hypothermia & [103] \\
\hline & - & $\begin{array}{l}\text { Animal study on six unrestrained bonnet } \\
\text { macaques (Macaca radiata É. Geoffroy); } \\
\text { administered with } 0.10,0.25,0.50 \text {, or } 0.75 \\
\mathrm{mg} / \mathrm{kg}(0.93-9.74 \mathrm{mg}) \text { of yohimbine orally }\end{array}$ & $\begin{array}{l}\text { Distress symptoms, freezing } \\
\text { behaviors, clonic jaw movements, } \\
\text { excessive yawning, } \\
\text { and sexual arousal }\end{array}$ & [104] \\
\hline & Clonidine & $\begin{array}{c}\text { Randomized double-blind } \\
\text { placebo-controlled study on } 53 \text { participants: } \\
38 \text { subjects with panic disorders with a } \\
\text { mean }( \pm \text { SD) age of } 35( \pm 2) \text { years- } 11 \text { males } \\
\text { and } 27 \text { females; and } 15 \mathrm{HC} \text { with a mean } \\
( \pm \text { SD) age of } 30( \pm 3) \text { years }-5 \text { males and } \\
10 \text { females; administered with } 0.4 \mathrm{mg} / \mathrm{kg} \text { of } \\
\text { yohimbine over } 10 \mathrm{~min}\end{array}$ & Anxiety and panic attacks & [105] \\
\hline & Glyburide, alcohol & $\begin{array}{l}\text { Case report of an acute yohimbine } \\
\text { intoxication of a diabetic } 63 \text {-year-old man; } \\
\text { took } 100 \times 2 \text { mg of yohimbine tablets in } \\
\text { about } 90-120 \text { min }\end{array}$ & Anxiety and alertness & [106] \\
\hline
\end{tabular}


Table 1. Cont

\begin{tabular}{|c|c|c|c|c|}
\hline $\begin{array}{l}\text { Plant/Active } \\
\text { Ingredients }\end{array}$ & Co-Exposure & Study, Participants, Age, and Sex & Neurological/Psychiatric Effects & References \\
\hline & Tolazoline, xylazine & $\begin{array}{c}\text { Animal study on four healthy horses-three } \\
\text { mares and one gelding; administered with } \\
0.025 \mathrm{mg} / \mathrm{kg} \text { of yohimbine every } 2 \mathrm{~min} \text { until a } \\
\text { maximal dose of } 2.0 \mathrm{mg} / \mathrm{kg}\end{array}$ & $\begin{array}{l}\text { Agitation, muscular tremors, } \\
\text { mild excitement, and reduction in } \\
\text { xylazine-mediated sedation }\end{array}$ & [107] \\
\hline & - & $\begin{array}{c}\text { Clinical study on eight narcoleptic } \\
\text { participants, four males with a mean age of } \\
43.5 \text { years (range } 22-64 \text { ) and four females } \\
\text { with a mean age of } 26 \text { years (range } 21-39 \text { ); } \\
\text { administered with } 2.7,5.4 \mathrm{mg} \text { of yohimbine } \\
\text { tablets twice daily up to } 16.2 \mathrm{mg} / \text { day }\end{array}$ & Insomnia, tremors, and flushing & [108] \\
\hline & $\begin{array}{l}\text { Fluoxetine, TCAs, propranolol, } \\
\text { benzodiazepines }\end{array}$ & $\begin{array}{l}\text { Four case reports of a 44-, two 45-, and a } \\
\text { 53-year-old males with PTSD; took “high” } \\
\text { quantity of over-the-counter yohimbine }\end{array}$ & $\begin{array}{l}\text { Sexual arousal, sweating, shaking, } \\
\text { panic attacks, and flashbacks }\end{array}$ & [109] \\
\hline & {$\left[{ }^{15} \mathrm{O}\right] \mathrm{H}_{2} \mathrm{O}$} & $\begin{array}{c}\text { PET scans in a single-blind fixed-order study } \\
\text { on nine participants with a mean age of } \\
30.7 \text { years-three males and six females; } \\
\text { administered with } 0.15 \mathrm{mg} / \mathrm{kg} \text { up to a } \\
\text { maximum dose of } 10 \mathrm{mg} \text { of yohimbine over } \\
3 \mathrm{~min}\end{array}$ & $\begin{array}{l}\text { Panic attack (one subject) and } \\
\text { increased anxiety }\end{array}$ & [110] \\
\hline & Morphine, U-50,488, SNC80 & $\begin{array}{l}\text { Animal study on } 318 \text { male OF1 mice and } \\
\text { male Sprague Dawley rats; administered } \\
\text { with } 2 \text { and } 4 \mathrm{mg} / \mathrm{kg} \text { of yohimbine IP }\end{array}$ & $\begin{array}{l}\text { Blockage of opioid-mediated } \\
\text { spinal antinociception }\end{array}$ & [111] \\
\hline & benzodiazepines, $\left[{ }^{11} \mathrm{C}\right]$ flumazenil & $\begin{array}{l}\text { Animal study on three adult male rhesus } \\
\text { monkeys; administered with } 0.4 \mathrm{mg} / \mathrm{kg} \\
\text { of yohimbine }\end{array}$ & $\begin{array}{l}\text { Increased binding potential for BDZ } \\
\text { receptors in the hippocampus } \\
\text { and anxiety }\end{array}$ & [112] \\
\hline & - & $\begin{array}{c}\text { Randomized, double-blind, } \\
\text { placebo-controlled study on } 17 \text { participants: } \\
8 \text { methadone-maintained subjects with a } \\
\text { mean }( \pm \text { SD) age of } 38( \pm 2.6) \text { years }-6 \text { males } \\
\text { and } 2 \text { females; and } 9 \text { male HC with a mean } \\
( \pm \text { SD) age of } 30( \pm 3.7) \text { years; administered } \\
\text { with } 4 \mathrm{mg} / \mathrm{kg} \text { of yohimbine over } 10 \text { min }\end{array}$ & $\begin{array}{l}\text { Precipitation of withdrawal and } \\
\text { craving symptoms in } \\
\text { methadone patients }\end{array}$ & [113] \\
\hline
\end{tabular}


Table 1. Cont

\begin{tabular}{|c|c|c|c|c|}
\hline $\begin{array}{l}\text { Plant/Active } \\
\text { Ingredients }\end{array}$ & Co-Exposure & Study, Participants, Age, and Sex & Neurological/Psychiatric Effects & References \\
\hline & $\begin{array}{l}\text { Xylazine, ketamine, buprenorphine, } \\
\text { gentamicin, methamphetamine }\end{array}$ & $\begin{array}{l}\text { Animal study on } 73 \text { male Long-Evans rats; } \\
\text { administered with } 1.25 \text { or } 2.5 \mathrm{mg} / \mathrm{kg} \text { of } \\
\text { yohimbine IP after extinction and } 0.625 \mathrm{mg} / \mathrm{kg} \\
\text { after } 21-51 \text { days of withdrawal }\end{array}$ & $\begin{array}{l}\text { Reinstatement of extinguished } \\
\text { methamphetamine seeking behavior }\end{array}$ & [114] \\
\hline & $\begin{array}{l}\text { Cocaine, clonidine, } \\
\text { RS-79948, flupenthixol }\end{array}$ & $\begin{array}{l}\text { Animal study on } 14 \text { adult squirrel monkeys } \\
\text { (Saimiri sciureus L.); administered with } 0.1 \text { and } \\
0.56 \mathrm{mg} / \mathrm{kg} \text { of yohimbine IP before the } \\
\text { reinstatement test }\end{array}$ & $\begin{array}{l}\text { Reinstatement of extinguished } \\
\text { cocaine seeking behavior }\end{array}$ & [115] \\
\hline & - & $\begin{array}{c}\text { Randomized double-blind placebo-controlled } \\
\text { study on } 13 \text { male participants with a mean } \\
( \pm \text { SD) age of } 24.9( \pm 2.2) \text { years; administered } \\
\text { with } 0.4 \mathrm{mg} / \mathrm{kg} \text { of yohimbine IV, procedure } \\
\text { repeated after } 14 \text { days }\end{array}$ & $\begin{array}{l}\text { Increased restlessness, anxiety, } \\
\text { and impaired mood }\end{array}$ & [116] \\
\hline & Pentobarbital & $\begin{array}{l}\text { Animal study on } 12 \text { adult male Sprague } \\
\text { Dawley rats; administered with } 0.1,1.0, \\
\text { or } 10.0 \mathrm{mg} / \mathrm{kg} \text { of yohimbine IP }\end{array}$ & $\begin{array}{l}\text { Suppression of P13 and N40 auditory } \\
\text { circuitry components at high doses } \\
\text { and increment of amplitude at } \\
\text { low/moderate doses }\end{array}$ & [117] \\
\hline & - & $\begin{array}{c}\text { Case report of an acute yohimbine } \\
\text { intoxication of a 37-year-old male body } \\
\text { builder; took } 5 \text { g of yohimbine, found with } \\
5240,2250,1530 \text {, and } 865 \mathrm{ng} / \mathrm{mL} \text { in blood } 3,6 \text {, } \\
14 \text {, and } 22 \mathrm{~h} \text {, respectively, after ingestion and } \\
50 \mathrm{mg} / \mathrm{L} \text { in urine at admission }\end{array}$ & $\begin{array}{l}\text { General malaise, vomiting, loss of } \\
\text { consciousness, } \\
\text { and tonic-clonic seizures }\end{array}$ & [118] \\
\hline & - & $\begin{array}{l}\text { Randomized double-blind placebo-controlled } \\
\text { study on } 24 \text { claustrophobic participants, } \\
12 \text { yohimbine-receiving subjects and } \\
12 \text { placebo-receiving patients, } 79 \% \text { females } \\
\text { with a mean }( \pm \mathrm{SD}) \text { age of } 24.46( \pm 8.65) \text { years } \\
\text { (males not reported); administered with } \\
2 \times 5.4 \mathrm{mg} \text { of yohimbine pills, procedure } \\
\text { repeated after } 14 \text { days }\end{array}$ & $\begin{array}{l}\text { Significant improvement in peak fear } \\
\text { at the one-week follow-up } \\
\text { behavioral assessment }\end{array}$ & [119] \\
\hline
\end{tabular}


Table 1. Cont.

\begin{tabular}{|c|c|c|c|c|}
\hline $\begin{array}{l}\text { Plant/Active } \\
\text { Ingredients }\end{array}$ & Co-Exposure & Study, Participants, Age, and Sex & Neurological/Psychiatric Effects & References \\
\hline & $\begin{array}{l}\text { Xylazine, ketamine, pentobarbital, } \\
\text { chloral hydrate, cefazoline, } \\
\text { heparin, heroin }\end{array}$ & $\begin{array}{c}\text { Animal study on } 22 \text { male Sprague Dawley } \\
\text { rats; administered with } 1.25 \text { and } 2.5 \mathrm{mg} / \mathrm{kg} \\
\text { of yohimbine IP } 30 \mathrm{~min} \text { before } \\
\text { reinstatement sessions }\end{array}$ & $\begin{array}{l}\text { Stress and reinstatement of } \\
\text { extinguished heroin seeking behavior }\end{array}$ & [120] \\
\hline & - & $\begin{array}{c}\text { Randomized, double-blind, } \\
\text { placebo-controlled study on } 24 \text { male } \\
\text { participants: } 12 \text { athletes with an average } \\
\text { age of } 29 \text { years and } 12 \text { untrained HC with } \\
\text { an average age of } 29.5 \text { years; administered } \\
\text { with } 0.4 \mathrm{mg} / \mathrm{kg} \text { of yohimbine IV }\end{array}$ & Anxiety & [121] \\
\hline & Nicotine, acamprosate & $\begin{array}{c}\text { Randomized, double-blind, } \\
\text { placebo-controlled study on } 35 \text { participants: } \\
12 \text { acamprosate-receiving subjects with a } \\
\text { mean }( \pm \text { SD) age of } 44.4( \pm 1.6) \\
\text { years- } 11 \text { males and } 1 \text { female; } \\
\text { and } 13 \text { placebo-receiving patients with a } \\
\text { mean }( \pm \text { SD) age of } \\
44.1( \pm 1.9) \text { years }-11 \text { males and } 2 \text { females; } \\
\text { administered with } 0.4 \mathrm{mg} / \mathrm{kg} \text { of } \\
\text { yohimbine IV }\end{array}$ & Increase in alcohol craving symptoms & [122] \\
\hline & $\begin{array}{c}\text { Clonidine, } \\
\text { 2-[ }\left[{ }^{18} \text { F]-fluoro-2-deoxy-D-glucose }\right.\end{array}$ & $\begin{array}{c}\text { Randomized, double-blind, } \\
\text { placebo-controlled study on } 22 \text { participants, } \\
11 \text { patients with IBS with a mean }( \pm \text { SD) age } \\
\text { of } 40.5( \pm 12.9) \text { years and } 11 \mathrm{HC} \text { with a } \\
\text { mean }( \pm \text { SD) age of } 37.3( \pm 10.6) \text { years; } \\
\text { administered with } 40 \mathrm{mg} \text { of } \\
\text { yohimbine tablet }\end{array}$ & $\begin{array}{l}\text { Increased anxiety and reduced brain } \\
\text { activity in the anterior cingulate } \\
\text { cortex, amygdala, dorsal brainstem, } \\
\text { and posterior insula }\end{array}$ & [123] \\
\hline & $\begin{array}{c}\text { Nicotine, ketamine, xylazine, } \\
\text { buprenorphine, bupivacaine, penicillin }\end{array}$ & $\begin{array}{l}\text { Animal study on } 84 \text { Long-Evans juvenile } \\
\text { rats; administered with } 0.3 \text { and } 0.6 \mathrm{mg} / \mathrm{kg} \\
\text { of yohimbine IP before operative sessions }\end{array}$ & Increased nicotine self-administration & [124] \\
\hline
\end{tabular}


Table 1. Cont

\begin{tabular}{|c|c|c|c|c|}
\hline $\begin{array}{l}\text { Plant/Active } \\
\text { Ingredients }\end{array}$ & Co-Exposure & Study, Participants, Age, and Sex & Neurological/Psychiatric Effects & References \\
\hline & Alcohol, d-Phe CRF & $\begin{array}{l}\text { Animal study on } 60 \text { rats (strain not } \\
\text { reported); administered with } 1.25 \mathrm{mg} / \mathrm{kg} \text { of } \\
\text { yohimbine IP before alcohol } \\
\text { self-administration and } \\
\text { reinstatement sessions }\end{array}$ & $\begin{array}{l}\text { Increased alcohol self-administration } \\
\text { and reinstatement of alcohol } \\
\text { seeking behavior }\end{array}$ & [125] \\
\hline & Caffeine, diphenhydramine, alcohol & $\begin{array}{l}\text { Two fatal case reports of acute yohimbine } \\
\text { intoxication of } 23-\text { and } 37 \text {-year-old males; } \\
\text { found } 7400 \mathrm{ng} / \mathrm{mL} \text { in iliac blood and } \\
5400 \mathrm{ng} / \mathrm{mL} \text { in heart blood, respectively }\end{array}$ & Seizures, elevated vitals, and death & [126] \\
\hline & Pioglitazone, naltrexone, alcohol & $\begin{array}{c}\text { Animal study on } 193 \text { genetically selected } \\
\mathrm{msP} \text { male rats; administered with } \\
1.25 \mathrm{mg} / \mathrm{kg} \text { of yohimbine IP } 1 \mathrm{~h} \text { after } \\
\text { naltrexone and before the } \\
\text { reinstatement session }\end{array}$ & $\begin{array}{l}\text { Reinstatement of alcohol } \\
\text { seeking behavior }\end{array}$ & [127] \\
\hline & Nicotine, caffeine, & $\begin{array}{c}\text { Randomized, double-blind, } \\
\text { placebo-controlled study on } \\
119 \text { participants: } 62 \text { cocaine-dependent } \\
\text { subjects with a mean }( \pm \text { SD) age of } 41.1 \\
( \pm 10.0) \text { years }-32 \text { males and } 30 \text { females; } \\
\text { and } 57 \text { HC with a mean }( \pm S D) \text { age of } 33.1 \\
( \pm 12.6) \text { years }-32 \text { males and } 30 \text { females; } \\
\text { administered with } 21.6 \text { mg of } \\
\text { yohimbine capsule }\end{array}$ & $\begin{array}{l}\text { Increase in anxiety and craving in } \\
\text { cocaine-dependent subjects }\end{array}$ & [128] \\
\hline & - & $\begin{array}{c}\text { Animal study on } 768 \mathrm{AB} \text { strain wild } \\
\text { zebrafish larvae, } 640 \text { yohimbine-receiving } \\
\text { animals; administered with } 10,25,50,100, \\
\text { or } 200 \mathrm{mg} / \mathrm{L} \text { of yohimbine solution, } \\
\text { and } 128 \mathrm{HC}\end{array}$ & anxiogenic at high concentrations & [129] \\
\hline & $\begin{array}{l}\text { MDMA, SCH-23390, atropine, } \\
\text { ketamine, xylazine }\end{array}$ & $\begin{array}{l}\text { Animal study on } 67 \text { male Sprague Dawley } \\
\text { rats; administered with } 2.0 \mathrm{mg} / \mathrm{kg} \text { before } \\
\text { reinstatement test and } 5.0 \mathrm{mg} / \mathrm{kg} \text { daily for } \\
10 \text { days for chronic treatment }\end{array}$ & $\begin{array}{c}\text { Anxiogenic effects and reinstatement } \\
\text { of extinguished MDMA } \\
\text { seeking behavior }\end{array}$ & [130] \\
\hline
\end{tabular}


Table 1. Cont

\begin{tabular}{|c|c|c|c|c|}
\hline $\begin{array}{l}\text { Plant/Active } \\
\text { Ingredients }\end{array}$ & Co-Exposure & Study, Participants, Age, and Sex & Neurological/Psychiatric Effects & References \\
\hline & naltrexone & $\begin{array}{c}\text { Double-blind, placebo-controlled study on } 16 \\
\text { healthy women aged between } 18 \text { and } 32 \text { years: } \\
5 \text { yohimbine + naltrexone-receiving patients, } \\
\text { and 11-placebo-receiving patients; } \\
\text { administered with } 16 \mathrm{mg} \text { of yohimbine orally } \\
\text { alone and co-administered with } 50 \mathrm{mg} \text { of } \\
\text { naltrexone orally }\end{array}$ & $\begin{array}{l}\text { Agitation, restlessness, anxiety, } \\
\text { headaches, nausea, light-headedness, } \\
\text { vomiting, weakness, lethargy, } \\
\text { tremors, blockage of analgesia in } \\
\text { ipsilateral forehead, and increase in } \\
\text { electrically evoked pain in forearm }\end{array}$ & [131] \\
\hline & Nicotine, THC & $\begin{array}{c}\text { Randomized, double-blind, } \\
\text { placebo-controlled study on } 95 \text { participants: } \\
39 \text { cocaine-dependent subjects with a mean } \\
( \pm \text { SD) age of } 41( \pm 1.7) \text { years }-12 \text { males and } \\
27 \text { females; and } 56 \text { HC with a mean }( \pm \text { SD) age } \\
\text { of } 33( \pm 1.7) \text { years }-32 \text { males and } 34 \text { females; } \\
\text { administered with } 21.6 \text { mg of yohimbine prior } \\
\text { to two cocaine exposure sessions }\end{array}$ & $\begin{array}{l}\text { Increased impulsivity in } \mathrm{HC} \text { and } \\
\text { slower hit reaction time in female } \\
\text { cocaine-dependent subjects }\end{array}$ & [132] \\
\hline & Hydrocortisone & $\begin{array}{l}\text { Randomized, double-blind, placebo-controlled } \\
\text { study on } 103 \text { participants with a mean }( \pm \text { SD) } \\
\text { age of } 24.79 \text { ( } \pm 0.36) \text { years-51 males and } 52 \\
\text { females randomly assigned to four } \\
\text { experimental groups (placebo, yohimbine, } \\
\text { hydrocortisone, yohimbine + hydrocortisone); } \\
\text { administered with } 20 \mathrm{mg} \text { of yohimbine orally }\end{array}$ & $\begin{array}{l}\text { Decreased memory generalization in } \\
\text { females (both yohimbine and } \\
\text { yohimbine + hydrocortisone groups) }\end{array}$ & [133] \\
\hline & Naltrexone & $\begin{array}{c}\text { Randomized, double-blind, } \\
\text { placebo-controlled study on } 39 \text { participants: } \\
13 \text { yohimbine-receiving patients and } \\
10 \text { placebo-receiving patients-13 males and } \\
10 \text { females aged between } 18 \text { and } 52 \text { years; } \\
5 \text { yohimbine + naltrexone-receiving females } \\
\text { and } 11 \text { placebo-receiving females aged } \\
\text { between } 18 \text { and } 32 \text { years; administered with } \\
16 \text { mg of yohimbine alone and co-administered } \\
\text { with } 50 \text { mg of naltrexone orally }\end{array}$ & $\begin{array}{l}\text { Nausea, headache, malaise, pain, } \\
\text { anxiety, and sexual arousal }\end{array}$ & [134] \\
\hline
\end{tabular}


Table 1. Cont.

\begin{tabular}{|c|c|c|c|c|}
\hline $\begin{array}{l}\text { Plant/Active } \\
\text { Ingredients }\end{array}$ & Co-Exposure & Study, Participants, Age, and Sex & Neurological/Psychiatric Effects & References \\
\hline & - & $\begin{array}{c}\text { Randomized, double-blind, } \\
\text { placebo-controlled study on } 42 \text { health } \\
\text { participants with a mean }( \pm \text { SD) age of } 21.29 \\
( \pm 3.27): 21 \text { yohimbine-receiving subjects } \\
\text { and } 21 \text { placebo-receiving } \\
\text { subjects- } 19 \text { males and } 23 \text { females; } \\
\text { administered with } 20 \text { mg of yohimbine } \\
\text { orally } 45 \text { min before behavioral test }\end{array}$ & $\begin{array}{l}\text { Anxiety, nervousness, nausea, } \\
\text { decreased motor and temporal } \\
\text { impulsivity, and increased } \\
\text { reflection impulsivity }\end{array}$ & [135] \\
\hline \multirow{3}{*}{$\begin{array}{l}\text { Piper methysticum G. } \\
\text { Forst. }\end{array}$} & $\begin{array}{l}\text { Alcohol, kavain }(450.1 \mathrm{mg} / \mathrm{L}), \\
\text { dihydrokavain }(456 \mathrm{mg} / \mathrm{L})\end{array}$ & $\begin{array}{c}\text { Alternated, double-blind, } \\
\text { placebo-controlled study on } 24 \text { participants } \\
\text { with a mean age of } 26.7 \text { years } \\
\text { (range }=18-53 \text { ), } 10 \text { males and } 13 \text { females; } \\
12 \text { subjects received } 500 \text { mL of kava juice } \\
\text { and } 12 \text { received placebo }\end{array}$ & $\begin{array}{c}\text { Body sway and decreased reaction } \\
\text { time tasks }\end{array}$ & [136] \\
\hline & Valerian & $\begin{array}{c}\text { Cross-over study on } 24 \text { participants with } \\
\text { stress-induced insomnia, } 9 \text { males with a } \\
\text { mean age of } 43.7 \text { years (range 23-65) and } \\
15 \text { females with a mean age of } 44.6 \text { (range } \\
\text { 30-65) years; administered with } \\
120 \text { mg/day of standardized kava extract } \\
\text { for } 6 \text { weeks }\end{array}$ & $\begin{array}{l}\text { Dizziness, vivid dreams, } \\
\text { and dry mouth }\end{array}$ & [137] \\
\hline & - & $\begin{array}{l}\text { Randomized, double-blind, } \\
\text { placebo-controlled study on } 38 \text { participants } \\
\text { with a previous history of GAD and a mean } \\
( \pm \text { SD) age of } 51.7( \pm 11.6) \text { years }-7 \text { males } \\
\text { and } 31 \text { females; administered } 140 \mathrm{mg} / \text { day } \\
\text { of standardized kava extract for } 1 \text { week } \\
\text { and } 280 \mathrm{mg} / \text { day for the next } 3 \text { weeks }\end{array}$ & $\begin{array}{l}\text { Bad taste in mouth, difficulty } \\
\text { achieving orgasm, drowsiness, } \\
\text { dry mouth, increased appetite, } \\
\text { muscle twitching, nausea, spasms or } \\
\text { drawing of muscles, sweating, } \\
\text { tingling or numbness, and trembling }\end{array}$ & [138] \\
\hline
\end{tabular}


Table 1. Cont.

\begin{tabular}{|c|c|c|c|c|}
\hline $\begin{array}{l}\text { Plant/Active } \\
\text { Ingredients }\end{array}$ & Co-Exposure & Study, Participants, Age, and Sex & Neurological/Psychiatric Effects & References \\
\hline & Benzodiazepines, fluoxetine, sertraline & $\begin{array}{l}\text { Case report of a kava intoxication of a } \\
\text { 45-year-old female with a family history of } \\
\text { essential tremor; took } 65 \mathrm{mg} / \text { day of kava } \\
\text { extract for } 10 \text { days }\end{array}$ & $\begin{array}{l}\text { Slow saccades, hypophonic speech, } \\
\text { generalized postural and tremor at } \\
\text { rest, severe generalized rigidity in } \\
\text { axial and appendicular muscles, } \\
\text { severe akinesia, gait disturbance with } \\
\text { lack of balance, and inability to walk }\end{array}$ & [139] \\
\hline & - & $\begin{array}{c}\text { Randomized, double-blind, } \\
\text { placebo-controlled study on } \\
141 \text { participants with neurotic anxiety: } \\
71 \text { subjects with a mean age of } 48.8 \text { (range } \\
18-69 \text { ) years, administered with } \\
3 \times 50 \mathrm{mg} \text { /day of standardized kava extract } \\
\text { for } 4 \text { weeks; and } 70 \text { placebo-receiving } \\
\text { subjects with a mean age of } 48.2 \text { (range } \\
18-69 \text { ) years-36 males and } 105 \text { females }\end{array}$ & $\begin{array}{l}\text { Withdrawal, aggravation of } \\
\text { anxiogenic symptoms, and tiredness }\end{array}$ & [140] \\
\hline & - & $\begin{array}{c}\text { Saccade and cognitive study on } 28 \\
\text { participants: } 11 \text { kava-intoxicated subjects } \\
\text { with a mean }( \pm \text { SD) age of } 38.1( \pm 10.3) \text { years } \\
\text { and } 17 \text { kava-users with a mean }( \pm \text { SD }) \text { age } \\
\text { of } 33.1( \pm 7.0) \text { years; took } 75-375 \mathrm{~g} \text { of } \\
\text { kava powder }\end{array}$ & $\begin{array}{l}\text { Ataxia, tremors, sedation, } \\
\text { disorientation, and blepharospasm }\end{array}$ & [141] \\
\hline & Kavain $(55 \%)$ & $\begin{array}{l}\text { Randomized, prospective, open study on } \\
68 \text { perimenopausal females: } \\
15 \text { kava-receiving subjects with a mean } \\
( \pm \text { SD) age of } 51.5( \pm 1.1) \text { years were } \\
\text { administered with } 100 \mathrm{mg} / \text { day of calcium } \\
\text { plus kava for } 3 \text { months; } 19 \text { kava-receiving } \\
\text { subjects with a mean }( \pm \text { SD) age of } \\
51.1( \pm 0.8) \text { years were administered with } \\
200 \mathrm{mg} / \text { day of calcium plus kava for } 3 \\
\text { months; and } 34 \text { HC with a mean }( \pm S D) \text { age } \\
\text { of } 50.2( \pm 0.6) \text { years }\end{array}$ & Nausea & [142] \\
\hline
\end{tabular}


Table 1. Cont.

\begin{tabular}{|c|c|c|c|c|}
\hline $\begin{array}{l}\text { Plant/Active } \\
\text { Ingredients }\end{array}$ & Co-Exposure & Study, Participants, Age, and Sex & Neurological/Psychiatric Effects & References \\
\hline & Flunitrazepam, flumazenil & $\begin{array}{l}\text { Animal study on } 40 \text { male sleep-disturbed } \\
\text { Wistar rats; administered with 10, 30, or } 300 \\
\mathrm{mg} / \mathrm{kg} \text { of a } 96 \% \text { ethanol kava extract }\end{array}$ & $\begin{array}{l}\text { Hypnosis (shorter sleep latency, } \\
\text { increase in the total non-REM time) }\end{array}$ & [143] \\
\hline & - & $\begin{array}{c}\text { Case report of an acute kava intoxication of } \\
\text { a 37-year-old male; took a "too strong" } \\
\text { kava tea }\end{array}$ & $\begin{array}{l}\text { Leg weakness, severe vertigo, nausea, } \\
\text { vomiting, diaphoresis, and dizziness }\end{array}$ & [144] \\
\hline & $\begin{array}{l}\text { Hypericum perforatum L., alcohol, } \\
\text { caffeine }\end{array}$ & $\begin{array}{c}\text { Randomized, double-blind, } \\
\text { placebo-controlled study on } 24 \text { participants } \\
\text { with MDD and a mean }( \pm \text { SD) age of } \\
42.9( \pm 8.8) \text { years }-20 \text { males and } 38 \text { females; } \\
\text { took } 3 \times 2.66 \mathrm{~g} / \text { day of herbal kava tablets } \\
\text { for } 10 \text { months }\end{array}$ & One case of withdrawal & [145] \\
\hline & $\begin{array}{c}\text { Dihydrokavain }(26 \%), \text { kavain }(21 \%), \\
\text { dihydromethysticin }(18 \%), \text { methysticin } \\
(14 \%), \text { yangonin }(13 \%), \\
\text { Desmethoxyyangonin }(8 \%)\end{array}$ & $\begin{array}{l}\text { Randomized, double-blind, } \\
\text { placebo-controlled study on } 28 \text { participants } \\
\text { with GAD and a mean }( \pm \mathrm{SD}) \text { age of } 30.1 \\
( \pm 12.4) \text { years }-7 \text { males and } 21 \text { females; } \\
\text { administered with } 120 \text { and } 240 \mathrm{mg} / \text { day of } \\
\text { kavalactones in } 3 \mathrm{~g} \text { tablets of standardized } \\
\text { extract of kava roots }\end{array}$ & $\begin{array}{l}\text { Increased females' sex drive and } \\
\text { difficulty to reach the orgasm in males }\end{array}$ & [146] \\
\hline & $\begin{array}{c}\text { Dihydrokavain }(26 \%), \text { kavain }(21 \%), \\
\text { dihydromethysticin }(18 \%), \text { methysticin } \\
(14 \%), \text { yangonin }(13 \%), \\
\text { desmethoxyyangonin }(8 \%)\end{array}$ & $\begin{array}{c}\text { Randomized, double-blind, } \\
\text { placebo-controlled study on } 58 \text { participants } \\
\text { with GAD and a mean }( \pm \mathrm{SD}) \text { age of } 30.1 \\
( \pm 8.8) \text { years, } 20 \text { males and } 38 \text { females; } \\
\text { administered with } 120 \text { or } 240 \mathrm{mg} / \text { day of } \\
\text { kavalactones in } 3 \mathrm{~g} \text { tablets of standardized } \\
\text { extract of kava roots }\end{array}$ & $\begin{array}{l}\text { Significant reduction in anxiety and } \\
\text { headaches }\end{array}$ & [147] \\
\hline & $\begin{array}{c}\text { Anxiolytics, antidepressants, } \\
\text { antinausea, antipsychotics, painkillers, } \\
\text { stimulants, sedatives, } \\
\text { meth/amphetamine, cannabis, cocaine, } \\
\text { ecstasy, hallucinogens, opiates, } \\
\text { benzylpiperazine, synthetic cannabis }\end{array}$ & $\begin{array}{l}\text { Survey study on } 434 \text { participants with a } \\
\text { mean }( \pm \text { SD) age of } 34.54( \pm 14.62) \\
\text { years- } 36.41 \% \text { males and } 63.59 \% \text { females, } \\
26 \text { kava-users }\end{array}$ & Driving-impairment & [148] \\
\hline
\end{tabular}


Table 1. Cont.

\begin{tabular}{|c|c|c|c|c|}
\hline $\begin{array}{l}\text { Plant/Active } \\
\text { Ingredients }\end{array}$ & Co-Exposure & Study, Participants, Age, and Sex & Neurological/Psychiatric Effects & References \\
\hline & Kavalactones & $\begin{array}{l}\text { Animal study on adult wild-type short-fin } \\
\text { outbred zebrafish with a } 1: 1 \text { male-to-female } \\
\text { ratio; administered with } 10,20 \text {, or } 50 \mathrm{mg} / \mathrm{L} \\
\text { of water extract from powdered kava roots } \\
\text { for } 20 \mathrm{~min} \text { and } 7.5 \mathrm{mg} / \mathrm{L} \text { for } 1 \text { week }\end{array}$ & Sedation and immobility & [149] \\
\hline Methysticin & DMSO & $\begin{array}{l}\text { Animal study on } 18 \text { AD model } \\
\text { mice-12 APP/Psen } 1 \text { strain and } 6 \text { wild-type } \\
\text { mice; administered with } 6 \mathrm{mg} / \mathrm{kg} \text { of } \\
\text { methysticin once a week for } 52 \text { weeks }\end{array}$ & Reduced movements & [150] \\
\hline \multirow{2}{*}{$\begin{array}{l}\text { Ptychopetalum olacoides } \\
\text { Benth. }\end{array}$} & Diazepam, pentylenetetrazol & $\begin{array}{l}\text { Animal study on CF1 strain male adult } \\
\text { mice parted in eight groups } \\
\text { (15-30 animals); administered with } 30,100 \text {, } \\
\text { or } 300 \mathrm{mg} / \mathrm{kg} \text { of ethanolic extract for } 30 \mathrm{~min}\end{array}$ & Reduced locomotion & [151] \\
\hline & $\begin{array}{l}\text { MK801, DMSO, scopolamine, } \\
\text { physostigmine }\end{array}$ & $\begin{array}{l}\text { Animal study on } 66 \text { CF1 strain male adult } \\
\text { albino mice; administered with } 50 \text { or } \\
100 \mathrm{mg} / \mathrm{kg} \text { of standardized ethanolic and } \\
100-800 \mathrm{mg} / \mathrm{kg} \text { once a day for } 21 \text { weeks }\end{array}$ & $\begin{array}{l}\text { Impairment of both short- and } \\
\text { long-term memories }\end{array}$ & [152] \\
\hline $\begin{array}{l}\text { Sceletium tortuosum (L.) } \\
\text { N. E. Brown }\end{array}$ & - & $\begin{array}{c}\text { Randomized, double-blind, } \\
\text { placebo-controlled study on } 21 \text { participants } \\
\text { with a mean }( \pm \mathrm{SD}) \text { age of } 54.6( \pm 6.0), \\
9 \text { males and } 12 \text { females; administered with } \\
25 \mathrm{mg} / \text { day of standardized extract } \\
\left(\text { Zembrin }{ }^{\circledR}\right) \text { for } 3 \text { weeks }\end{array}$ & $\begin{array}{l}\text { Headache, blurred vision, } \\
\text { poor hearing, nausea, vomiting, } \\
\text { appetite increase, muscles rigidity, } \\
\text { drowsiness, confusion, concentration } \\
\text { difficulty, memory problems, } \\
\text { depression, anxiety, and ataxia }\end{array}$ & [153] \\
\hline
\end{tabular}




\section{Discussion}

\subsection{Areca catechu L. (Betel Nut)}

Betel nut is one of the most widely used addictive substances in the world and represents the fourth most consumed drug after nicotine, ethanol, and caffeine $[23,154]$. The fruit, obtained from the palm tree, Areca catechu L., is commonly chewed in Southeast Asia and the South Pacific islands [155,156] for its antiparasitic, digestive, euphoric, and aphrodisiac effects $[157,158]$. There are two main ways to prepare areca nut for chewing: wrapping a split unripe nut with lime paste (calcium oxide) in a betel tree leaf or inserting a piece of Piper betel L. inflorescence with lime paste into an unripe areca nut $[22,154,159]$.

The betel nut contains a variety of active alkaloids responsible for its effects. The content of major alkaloids arecoline, arecaidine, guvacoline, and guvacine in the fresh nut is approximately $0.30-0.63 \%$, $0.31-0.66 \%, 0.03-0.06 \%$, and $0.19-0.72 \%$, respectively, although it may vary with maturation [160-163]. Due to the presence of calcium oxide, arecoline and guvacoline are hydrolyzed to arecaidine and guvacine, respectively, in basic conditions $[163,164]$. Areca alkaloids mediate the autonomic responses of the parasympathetic nervous system and the synaptic transmission in the peripheral nervous system [164-166], and impact various aspects of brain function and regulation [167,168]. Arecoline is a partial muscarinic (M) agonist and possesses a higher affinity for M receptors than guvacoline [24,169]. High arecoline doses produce nicotinic cholinergic effects [170]. As tertiary amines, arecoline and, to a lesser extent, arecaidine have a deep brain penetration [165,169]. It was demonstrated that arecoline enhances cognition and memory and significantly improves several behavioral disorders in patients with Alzheimer's disease or schizophrenia, through the activation of postsynaptic M1 receptors $[24,162,171]$. In addition, improvements in positive and negative symptoms of psychosis have been observed in schizophrenic areca nut chewers $[155,172,173]$. It is believed that arecoline reduces the dopaminergic hyperactivity underlying the positive symptoms of psychosis throughout the modulation of M1, M2, and M4 receptors, and induces dopamine release in the prefrontal cortex, the striatum, and the ventral tegmental area, ameliorating the negative symptoms $[169,174,175]$. Furthermore, the release of dopamine and other catecholamines causes stimulant and libido-enhancing effects $[3,156,166,176,177]$. These effects, coupled with the inhibition of monoamine oxidase A (MAO-A) caused by aromatic phenolic compounds of the plant, may also explain the antidepressant properties of the areca nut $[24,169]$.

High betel nut doses can cause typical muscarinic and extrapyramidal symptoms such as salivation, diaphoresis, diarrhea, gastrointestinal upset, emesis, vertigo, myosis, tremor, hyperthermia, bradycardia, and asthma attacks [156,158,166,168,176,178,179]. Furthermore, if betel nut is taken in high quantities, transient extrapyramidal symptoms including rigidity, bradykinesia, and jaw tremor may occur $[24,176,180]$. These effects are probably due to guvacine and arecaidine, which are strong inhibitors of $\gamma$-aminobutyric acid (GABA) reuptake and contribute to the reduction in spontaneous activity and body excitability [181-183]. However, it was also demonstrated that areca alkaloids reduce GABA affinity for the $\mathrm{GABA}_{\mathrm{A}}$ receptor, and arecaidine and guvacine effects on GABA signaling may cause epileptic seizures $[23,169,180,184]$. The main risks associated with the chronic consumption of betel nut are related to its metabolism. Indeed, areca alkaloids are converted into DNA alkylating nitrosamines, which cause cell proliferation and oxidative stress-dependent neurotoxicity, leading to oral carcinogenicity and exacerbating neurodegenerative disease symptoms $[24,158,183,185]$. Albeit its use is culturally well accepted, the betel nut is a strongly addictive substance and multiple adverse effects were reported (Table 1). Tolerance and nicotine/amphetamine-like withdrawal syndrome, characterized by insomnia, mood swings, irritability, and anxiety, may appear after repeated intakes $[16,167,179]$.

\subsection{Citrus aurantium L. (Bitter Orange)}

Citrus aurantium L., also called Seville orange, sour orange, or bitter orange, is a small tree belonging to the Rutaceae family. It is native to Eastern Africa, Arabia, and Syria, but is also cultivated in Spain, 
Italy, and North America [186]. Bitter orange tree's leaves, flowers, fruits peels, and seeds have been used for centuries to treat tachycardia, rheumatism, insomnia, anxiety, epilepsy, and gastrointestinal disorders and to enhance sexual desire [187-189].

The bitter orange tree contains vitamins, minerals, terpenoids, and flavonoids [190]. The most abundant flavonoids are hesperetin and naringenin, which possess, together with terpenoids, carotenoids, and ascorbic acid, a free radical-scavenging ability and inhibit proinflammatory mediators release, exerting a powerful antioxidant activity and reducing tumoral cell proliferation [191,192]. Terpenoids such as $d$-limonene, $\alpha$-pinene, $\beta$-myrcene, linalyl acetate, and linalool are the main volatile components of the plant $[193,194]$, and are distilled or extracted from blooms, leaves, and orange peel to obtain essential oils (EOs) [195]. These substances, especially d-limonene, modify the cell membrane of microbes and denature enzymes responsible for their germination and sporulation, showing antimicrobic and antifungal properties [191,196]. For these reasons, bitter orange tree's EOs are widely sold as flavoring and preservative agents in foods and drinks [190,197]. Recently, a great interest in these EOs has been observed in the context of alternative medicines such as aromatherapy. It was demonstrated that these substances, after vaporization and inhalation, are effective for treating different forms of anxiety, sleep, and libido, and reduce seizures in animal models [38,39,198-201]. The mechanism of action of the plant's ingredients, however, is not fully elucidated. Anxiolytic and hypnotic effects are seemingly due to the combination of the action of the plant's aroma on the limbic system through olfaction and the direct action of terpenes on GABAergic and serotoninergic $\left(5-\mathrm{HT}_{1 \mathrm{~A}}\right)$ receptors $[39,202,203]$.

Adverse effects are mild and transient; psychiatric and neurological effects are reported in Table 1. The US Food and Drug Administration confirmed that oral administration of bitter orange extracts is safe [39], and its derivatives have gained popularity as dietary supplements over the last few years [200,204]. Standardized derivatives containing 4-6\% synephrine, an ephedrine-like alkaloid naturally occurring in C. aurantium and possessing $\alpha$-and $\beta$-adrenergic properties, are available $[3,40,205]$. Although synephrine has become one of the most popular stimulants in weight loss products, cardiovascular adverse effects including increased blood pressure, tachycardia, ventricular fibrillation, transient collapse, myocardial infarction, and cardiac arrest have been reported [206]. Headache and gastrointestinal symptoms have also been reported.

\subsection{Mitragyna speciosa Korth. (Kratom)}

Kratom is an herbal preparation obtained from the leaves of Mitragyna speciosa Korth, an evergreen plant of the Rubiaceae family that grows spontaneously in Southeast Asia, mainly in Thailand and Malaysia [207]. In these countries, the plant has been exploited for centuries for its stimulant and narcotic properties and is commonly self-administrated by manual laborers to combat fatigue and improve productivity [51]. Mitragyna leaves are traditionally chewed, smoked, or boiled with hot water and served as a tea [208]. New preparations such as capsules, resins, or tinctures are now available on the Internet and are purchased in Europe and in America for recreational use or as herbal products $[209,210]$.

More than 40 alkaloids were isolated from kratom. The alkaloids' content is variable and depends on plant age, season, and geographical location [211]. Mitragynine is the most abundant active compound and accounts for up to $66 \%$ of the total mass of crude alkaloids extract. Other major alkaloids are paynantheine, which is the second most abundant alkaloid (10\% of total content), speciogynine, and speciociliatine. Among the various minor alkaloids, 7-hydroxymitragynine is of particular interest due to its important role in mediating the analgesic effect of mitragynine [157]. Both mitragynine and its oxidized metabolite 7-hydroxymitragynine are partial agonists of $\mu$-opioid receptors (MOR) and competitive antagonists of $\kappa$ - and $\delta$-opioid receptors (KOR and DOR), which are involved in analgesia. However, mitragynine affinity for opioid receptors is lower than that of morphine, while 7-hydroxymitragynine affinity is approximately 46 and 13 times higher than that of mitragynine and morphine, respectively [212]. The possible stimulant and libido-enhancing effects 
of mitragynine may be due to the blockade of serotonergic $5-\mathrm{HT}_{2 \mathrm{~A}}$ receptors and the postsynaptic stimulation of $\alpha_{2}$ adrenergic receptors $\left(\alpha_{2} \mathrm{R}\right)$ in the CNS [212]. Recently, LaBryer et al. hypothesized that kratom may have restored testosterone, luteinizing hormone (LH), follicle-stimulating hormone (FSH), and prolactin levels in a patient with hypogonadotropic hypogonadism [213]. Mitragynine also binds adenosine $A_{2 A}$ receptors, dopamine $D_{2}$ receptors, and serotonin receptors $5-\mathrm{HT}_{2 \mathrm{C}}$ and $5-\mathrm{HT}_{7}$, but the physiological significance of these interactions is unclear [214]. Data showed that low kratom doses (1-5 g) induce stimulating effects, involving the release of neurotransmitters by reversible blockade of calcium channels. At higher doses ( $>15 \mathrm{~g})$, it can cause sedative/narcotic effects, and the plant can be used as a general analgesic, as an opium substitute, or to treat opium withdrawal symptoms [215].

Studies have found that 7-hydroxymitragynine is the main contributor to the plant's toxicity and the development of addiction symptoms. In 2014, Singh et al. [51] reported a cross-sectional survey investigating the correlation between frequency and quantity of kratom consumption, and the risk of addiction development and the severity of withdrawal symptoms and craving in regular user [216]. Cessation of kratom use produced physical withdrawal symptoms similar to those of opiate addiction including pain, sleep disorders, muscle spasms, watery eyes, runny nose, hot flashes, fever, decreased appetite, diarrhea, and craving. Psychological withdrawal symptoms reported by users included restlessness, tension, anger, and depression [217] (Table 1).

\subsection{Panax ginseng C. A. Mey (Asian Ginseng) and Panax quinquefolius L. (American Ginseng)}

Ginseng is a perennial herbaceous plant of the family Araliaceae. Over twelve ginseng species were identified, although mainly Asian or Korean ginseng (P. ginseng) and American ginseng (P. quinquefolius) have been used for their therapeutic properties. Asian ginseng grows in East Asian mountains, while American ginseng is an endangered species that grows in deciduous forests of the west half of North America. Asian ginseng is an emblematic plant of traditional Chinese medicine, and is listed in the Shennong Ben Cao Jing, the most ancient Chinese book of herbal medications. A variety of pharmacological effects are attributed to ginseng. For example, it is used to improve intelligence, to treat impotence, to treat hemorrhage, to relax, and to slow aging [218]. American ginseng medical use is more recent and has gained popularity in Western countries over recent decades. Ginseng health benefits were demonstrated in many clinical studies in various fields: it has shown aphrodisiac, anti-inflammatory, anticancer (lung, liver, intestine, and stomach), antidiabetic, cardioprotective, gastroprotective, antiamnestic, and antioxidative (heart and kidney) properties [219]. The fresh root of ginseng can be directly chewed after peeling or soaked in wine for drinking and chewing. In China and Korea, it is boiled with chicken to prepare energy drinks, teas, and candies [218].

Asian and American ginseng contain a variety of pharmacologically active triterpene saponins, named ginsenosides. Ginsenosides are classified into two groups depending on the hydroxylation of their steroid core structure: the 20(S)-protopanaxadiol (PPD) and 20(S)-protopanaxatriol (PPT) groups. $\mathrm{Rb} 1, \mathrm{Rb} 2, \mathrm{Rb} 3, \mathrm{Rc}$, and $\mathrm{Rd}$ are the main PPD-type ginsenosides, and $\mathrm{Rg} 1$ and $\mathrm{Re}$ are the main PPT-type ginsenosides. A total of 32 ginsenosides, including the abovementioned compounds, are found in in both American and Asian ginseng, but the two plants also possess specific ginsenosides. The presence of Rf, a PPD/PPT ratio lower than 2, and a Rb1/Rg1 ratio lower than 5 usually identify Asian ginseng. The content of ginsenosides is affected by seasons, geographical distribution, and processing (fresh ginseng, steamed ginseng or white ginseng, and sun-dried ginseng or red ginseng) [220]. After oral administration, ginsenosides are mainly metabolized in the gastrointestinal tract and the liver, undergoing successive deglycosylations: $\mathrm{Rg} 3$ is a metabolite of $\mathrm{Rb} 1, \mathrm{Rb} 2, \mathrm{Rb} 3$, $\mathrm{Rc}$, and $\mathrm{Rd}$, and is further metabolized to Rh2; Rg2 is a metabolite of Re; and Rh1 is a metabolite of both Rg1 and Rg2. Ginsenosides have low oral bioavailability, owing to their low membrane permeability and their degradation in the gastrointestinal tract [219]. Rg1 induces NO synthesis in endothelial cells and perivascular nerves, and increases vascular smooth muscle sensitivity to $\mathrm{NO}$, prolonging the erection in males and enhancing sexual potency. In addition, P. ginseng was proved to increase testosterone, 
LH, and FSH in healthy volunteers through $\mathrm{Rg} 1$ and $\mathrm{Rb} 1$, enhancing libido. Re increases extracellular dopamine and acetylcholine in rat brains, while $\mathrm{Rb} 1$ increases choline reuptake at the synapses. $\mathrm{Rb} 1$, $\mathrm{Rb} 2, \mathrm{Rc}, \mathrm{Re}, \mathrm{Rf}$, and $\mathrm{Rg} 1$ are agonists of $\mathrm{GABA}_{\mathrm{A}}$ receptors and $\mathrm{Rc}$ is also an agonist of $\mathrm{GABA}_{\mathrm{B}}$ receptors. These modulations of several neurotransmission pathways may have an effect at different levels of the hypothalamus-pituitary-testis axis [221]. Mancuso and Santangelo recently reviewed the effects of ginsenosides on the immune system (e.g., modulation of the immune response, anti-inflammatory effects), the nervous system (e.g., regulation of the stress axis, improvement of memory and learning functions), and the cardiovascular system (e.g., improvement of cardiac performance, cardioprotective effects) [222].

American and Asian ginseng present a good safety profile with a few cases of mild gastrointestinal and sleep disorders. Psychiatric and neurological side effects are rare, and causality is difficult to ascertain $[77,79,80,82-87,89-94]$. In fact, most clinical studies with ginseng or ginsenosides reported no psychiatric or neurological side effects or statistically insignificant effects compared to placebo, and were not included in Table 1 [223-227]. A few cases of headache following ginseng administration were reported without placebo control [84,91]. Insomnia, agitation, and fatigue were more frequent [82-84,89,94], but still uncommon. More interestingly, several cases of manic-like effects, such as confusion, agitation, irritation, nervousness, anxiety, and bizarre behavior, without history of psychiatric disorder, were reported following ginseng use $[77,78,81,85,87,88,90,228]$. These cases, however, were isolated and generally resulted from high ginseng doses or with the concomitant use of other substances (e.g., phenelzine, cannabis, herbal supplements); mania was not reported in clinical studies using ginseng alone or in combination. In fact, ginseng toxicity mainly comes from drug interactions with cytochromes P450 (CYPs) CYP3A4 and CYP2D6 inhibitors and serotoninergic drugs, intensifying sedative effects or inducing cognitive disorders or a serotonin syndrome [229-231].

\subsection{Pausinystalia johimbe (K. Schum.) Pierre ex Beille (Yohimbe)}

Pausinystalia johimbe (K. Schum.) Pierre ex Beille, also known as yohimbe, is an evergreen tree of the Rubiaceae family that mainly grows in the tropical region of the African West coast, where the bark has been consumed as an aphrodisiac for the treatment of erectile dysfunction [157,232].

The bark of the plant contains several structurally related indole alkaloids, yohimbine being the most abundant one (10-15\% of total content), followed by its stereoisomers $\alpha$-yohimbine, $\beta$-yohimbine, $\psi$-yohimbine, corynanthine, allo-yohimbine, and yohimbic acid $[233,234]$. Yohimbine is marketed as a pharmaceutical prescribed for the treatment of erectile impotence and has been used in multiple clinical trials as a probe to identify abnormal physiological and affective responses to increased noradrenergic signaling, especially in patients with panic disorders $[235,236]$. Yohimbine is a potent selective $\alpha_{2} R$ antagonist with weaker $\alpha_{1} R$ antagonist activity that blocks the presynaptic feedback inhibition of noradrenaline release, prolonging the excitatory effects of noradrenaline at postsynaptic $\alpha_{1} R$ and $\beta$-receptors $[237,238]$. Yohimbine has a relatively short half-life due to an extensive hepatic metabolism, which produces two main hydroxylated metabolites, 11- and 10-hydroxyyohimbine, that are rapidly excreted in urine $[239,240]$. There is increasing interest in botanic dietary supplements containing yohimbine extracts in the context of sexual and body enhancement [241].

Yohimbine readily passes the blood-brain barrier after absorption, causing an increase in sympathetic tone and blood pressure through the blockade of central medullary $\alpha_{2} R$ [242], and provokes noradrenergic perturbation in limbic forebrain structures like amygdala and locus coeruleus, leading to mood and behavior alterations (Table 1). Due to these potential cardiac and neurological adverse effects, yohimbine was used in patients with difficulties to reach orgasm, with erectile dysfunction, or with low libido, mainly before the emergence of phosphodiesterase 5 (PDE5) inhibitors (e.g., sildenafil), which present a better safety profile $[243,244]$. The yohimbine mechanism of action is currently unclear. There is evidence suggesting that yohimbine increases libido by blocking $\alpha_{2} R$ in the locus coeruleus, which is involved in the control of the erection. Peripherally, it was suggested that yohimbine enhances NO release from cavernosal endothelial cells, producing a relaxation of smooth muscle cells and 
consequent erection, increasing sexual potency [3,6,237]. Moderate to severe adverse effects like sweating, flushing, hypertension, tachycardia, palpitations, bronchospasm, chest pain, and atrial fibrillation are reported after deliberate or accidental ingestion, while lethal intoxications are extremely rare $[245,246]$.

\subsection{Piper methysticum G. Forst. (Kava)}

Native to Western Pacific islands where the shrub is traditionally called "ava", "wati", or "yagona", kava (Piper methysticum G. Forst) grows in humid and shaded areas of tropical regions. This is a perennial Piperaceae with a massive rhizome weighing up to a dozen kilograms [19]. Kava is considered as a sacred beverage in Pacific islands [247]. The plant has also been used in traditional medicine, first as a treatment for venereal diseases, then later as a sedative and treatment for anxiety and sleep disorders, to decrease fatigue, and to relieve pain [248].

Eighteen active compounds named kavalactones were identified in kava, but only six, i.e., methysticin, dihydromethysticin, kawain, dihydrokawain, desmethoxyyangonin, and yangonin, have been the focus of kava studies as they account for up to $96 \%$ of organic extracts (acetonic or ethanolic extraction). Kava also contains a variety of other non-lactone compounds, i.e., flavokawains A, B, and C, 5,7-dimethoxyflavanone, cinnamic acid bornyl ester, flavanones, fatty acids, and a chalcone. Kava effects may be the result of a synergy of the six major kavalactones [249]. Kava extracts produce a similar activity profile as that of benzodiazepines, which interact with GABA receptors, inhibit the MAO-B, and inhibit dopamine and noradrenaline reuptake in the CNS, inducing libido-enhancing properties [250]. In vitro studies of the hippocampus and other brain regions suggest that the sedative effects of kavalactones may be mediated by an increase in $\mathrm{GABA}_{\mathrm{A}}$ receptor binding sites [251,252]. It was demonstrated that several kavalactones are potent inhibitors of several CYP metabolic enzymes [253]. Oral pharmacokinetics of kawain $(100 \mathrm{mg} / \mathrm{kg})$ were determined in rats with and without co-administration of kava extract (256 mg/kg). The results showed that kawain was well absorbed, and more than $90 \%$ of the dose was eliminated within $72 \mathrm{~h}$, mainly in urine [254].

Data on kava's safety profile obtained from clinical trials in patients with anxiety suggest generally good tolerability and safety for short-term use (1-4 weeks) at therapeutic doses. However, the use of kava at frequent and high doses can cause hepatotoxicity through the modulation of various CYP, which is also the cause of potential drug interactions [255], dermopathy [256], and cognitive disorders [257]. Sedation with drowsiness and dizziness is commonly reported in clinical trials with administration of kava or methysticin (Table 1), which may impair driving performances [148].

\subsection{Ptychopetalum olacoides Benth. (Muirapuama)}

Ptychopetalum olacoides Benth. is a popular Amazonian tree belonging to the Olacaceae family. It is also known in Brazil as marapuama or muirapuama [258]. The native communities have used its roots and barks as a treatment for depression, sexual dysfunction, and as a "nerve tonic" [259]. Roots are usually prepared in alcoholic infusion, but other formulations have also been employed (e.g., mixture of extracts, solutions, pills) [260].

Muirapuama root bark produces a volatile oil containing $\alpha$-pinene, $\alpha$-humulene, $\beta$-pinene, $\beta$-caryophyllene, camphene, and camphor. Fatty acids such as uncosanoic, tricosanoic, and pentacosanoic acids account for up to $20 \%$ of the total lipophilic components of the plant [261]. Other compounds detected in muirapuama are fatty acid esters of sterols, coumarin, free fatty acids, and free sterol; a small quantity of $\beta$-sitosterol was also detected [262]. Based on ethnopharmacological data, it can be hypothesized that muirapuama interacts with the dopaminergic system, increasing libido; the noradrenergic system, inducing antidepressant effects; and the serotonergic system, modulating appetite. The antinociceptive effects of the plant were investigated in thermal and chemical models of nociception in mice. Data showed that the maximal effect was reached $6 \mathrm{~h}$ after administration of a low dose of muirapuama extract and produces significant and long-lasting (up $12 \mathrm{~h}$ ) effects in both chemical and thermal tests of nociception in mice. In addition, higher doses, either acutely or 
subchronically (15 days), did not cause a worsening of adverse effects [263]. A few neurological side effects were reported in preclinical studies, including impairment of both short- and long-term memory and reduced locomotion [151,152] (Table 1).

\subsection{Sceletium tortuosum (L.) N. E. Brown (Kanna)}

Kanna, or Channa, is the traditional name of a succulent, perennial plant belonging to the Aizoaceae family (earlier Mesembrynantheaceae) that is indigenous to South Africa, where it is consumed by local tribes to relieve thirst and hunger and combat fatigue [264,265]. The dried aerial parts of the plant are commonly chewed or consumed as teas, decoctions, and tinctures and sometimes smoked or snuffed [266].

Kanna's main active compounds are mesembrine, mesembrenol, mesembrenol, and mesembrenone, which are synthesized in the plant through the condensation of phenylalanine and tyrosine amino acids. Kanna alkaloids inhibit serotonin reuptake and PDE4A, potentially enhancing sexual potency and libido [267-269]. In fact, the plant is widely sold over the Internet and specialized herbal shops to increase sexual performance, although its mechanism of action and effects were not clearly demonstrated. This dual inhibitory effect has been studied for the development of compounds for the treatment of cognition impairment, motor dysfunction, depression, and neurodegeneration [270]. Mesembrenone is the most potent inhibitor of PDE4A, while mesembrine is more selective towards the serotonin receptor. In addition, mesembrine is also an agonist of $\mathrm{GABA}_{\mathrm{A}}$, $\delta_{2}$-opioid, $\mu$-opioid, cholecystokinin-1, E4-prostaglandin, and melatonin-1 receptors at high doses, and shows antinociceptive effects in animal models [266,270-273]. Recently, S. tortuosum has been marketed for the treatment of mild depression and to improve mood [274]. Zembrin ${ }^{\circledR}$, a standardized hydroalcoholic extract, was found to be safe and well-tolerated in preclinical studies with mild adverse effects (Table 1) and is widely sold as a dietary supplement [275]. Another commercially available product is Trimesemine ${ }^{\mathrm{TM}}$, a highly-concentrated mesembrine extract $(3 \%$ mesembrine $(w / w))$ that shows a great upregulation of the expression of vesicular monoaminetransporter-2 (VMAT-2), increasing monoamines release as the primary pharmacological effect [276,277]. Kanna alkaloids are metabolized in the liver to $\mathrm{O}, \mathrm{N}$-demethylated or dehydroxylated compounds, which are then excreted as glucuronides or sulfates conjugates $[277,278]$.

\subsection{Other Plants}

Little evidence was found on the psychiatric and neurological side effects of several sexual enhancers that were originally included in this review: A. Mexicana, E. longifolia, L. meyenii, T. diffusa, $V$. africana, and W. somnifera.

The safety of maca (Lepidium meyenii Walp.) and ashwagandha or Indian ginseng (Withania somnifera (L.) Dunal) is well-documented. Maca is an edible herbaceous plant of the Andes Mountains and has been used for centuries for improving male and female sexual function. A renewed interest for maca has been observed from the 1990s onwards, and pills, capsules, flour, liquor, and extracts are now massively produced and exported [279]. The plant, however, presents a good safety profile [279], and only one case of a manic-like episode following consumption in a patient without history of psychiatric disorders was reported [280]. Ashwagandha is an evergreen shrub of the family Solanaceae, which is cultivated in hot and dry areas of tropical and subtropical regions of the world. Ashwagandha has numerous applications in traditional Indian medicines and has been used for more than 5000 years as an aphrodisiac, antioxidant, antimicrobial, adaptogenic, diuretic, tonic, narcotic, immuno-stimulant, anti-inflammatory agent, anti-stress, antiulcer, among many other purposes. Positive effect in insomnia, anxiety, chronic stress, weight management, thyroid gland function, telomerase, cardio-respiratory endurance, muscle strength, recovery of male and female sexual function, and senescence was demonstrated in preclinical and clinical studies [164]. Excellent tolerability is generally reported after using ashwagandha for weeks at therapeutic doses, with statistically insignificant adverse effects compared to placebo [281,282]. 
Other plants have been little studied, although some of them are well-known remedies that have been used for many years. Further investigation is necessary to clearly understand the possible neurological and psychiatric effects caused by these plants. For example, damiana (Turnera diffusa Willd. Ex. Schult.), a Central American shrub of the family Passifloraceae, has been traditionally used for centuries as a stimulant and aphrodisiac, to spark male sexual drive and increase performance, and is still widely marketed [283]. Recently, the plant also proved to induce anxiolytic and antidepressant effects in preclinical studies $[283,284]$. However, no psychiatric or neurological side effects related to damania were reported. Another interesting example is Voacanga africana Stapf ex Scott-Elliot, a shrub/small tree of tropical Africa whose seeds have been recently commercialized as a poison, stimulant, aphrodisiac, and ceremonial psychedelic [285]. Although the plant contains a variety of indole alkaloids related to ibogaine, a well-known psychoactive substance from iboga (Tabernanthe iboga Baill.) that has also been used as an aphrodisiac [286], there is no evidence of positive effects on sexual function. In addition, although Voacanga africana alkaloids may modulate neuronal excitability and have positive effects in Alzheimer's disease $[287,288]$, no neurological or psychiatric complications related to the plant were reported. There is also little information on the side effects of the Mexican poppy (Argemone mexicana L.) and Tongkat Ali (Eurycoma longifolia Jack.).

Other herbal aphrodisiacs that were not included in this literature review are commonly used, but data on their safety profile are also limited [14].

\subsection{General Discussion}

The psychiatric and neurological side effects caused by the consumption of herbal aphrodisiacs are mild, with mostly no consequences at therapeutic doses. Although rare, psychiatric side effects were mostly reported and included anxiety, depression, psychosis, and mania. Neurological effects included seizures, extrapyramidal symptoms, and withdrawal symptoms. Dizziness, sleepiness, fatigue, agitation, insomnia, and headaches were reported. As expected, all the plants involved are libido-enhancing aphrodisiacs altering neurotransmission, although ginseng $(P$. ginseng and $P$. quinquefolius) and yohimbe (P. johimbe), and kanna (S. tortuosum) also enhance sexual potency. Kratom (M. speciosa) and yohimbe presented the highest rate of side effects, but yohimbe's general toxicity is mainly cardiovascular, due to its effects on the NO pathway. These mild effects were not anticipated, considering the mechanism of action of these plants. However, they did not come as a complete surprise, because these plants have been used for centuries or millennia in traditional medicines and modern medicine has considerably benefited from these ingredients and preparations [289].

Few clinical reports and few data were found for the side effects of bitter orange (C. aurantium), muirapuama (P. olacoides), and kanna (S. tortuosum), and only preclinical reports were found for muirapuama. There were no reports on the side effects of damania (T. diffusa), the Mexican poppy (A. mexicana), and Tongkat Ali (E. longifolia). Although several of these plants have been used for centuries in traditional medicines, they have not been as extensively studied as the other plants included in this review. Therefore, this result was not surprising. Psychiatric and neurological side effects included headaches and hypnotic effects and were mild. Although the consumption of these plants appears safe, further studies should be conducted to better understand their positive and negative effects.

Herbal aphrodisiacs are readily available on the Internet and specialized shops and markets. Aside from sexual enhancement, these plants often have many other therapeutic applications and can be a part of the everyday diet of individuals. In addition, self-medication is frequent, as they are available without a prescription, and plant extracts provided by retail herbal stores may also be mislabeled or adulterated (e.g., heavy metals, pharmaceuticals) [290]. Consequently, these plants are often taken concomitantly with contaminants, medications, and other herbal therapies or dietary supplements: drug interactions represent the most significant health risks of herbal aphrodisiacs and psychiatric and neurological adverse effects have been reported [230]. Medical doctors should be 
aware of the potential drug interactions with aphrodisiacs and dietary supplements when prescribing a pharmaceutical drug.

\subsection{Limitations}

Considering the paucity of data and the frequent co-exposure to other psychoactive substances, conclusions can be hardly drawn regarding the psychiatric/neurological adverse effects of several of the plants included in this article. In particular, more clinical studies with controlled administrations, to have a better grasp on doses and co-exposures, should be conducted to address this issue.

Another limitation is the choice of the keywords used for the literature search. The review focused on selected plants and their active ingredients, which were included after a preliminary screening of the literature. Other less common herbal aphrodisiacs might have eluded the search.

Additionally, only articles written in English, Italian, and French were included in the review, and reports written in another language were excluded. This limitation is particularly relevant considering the prevalence of traditional Ayurvedic, Unani, and Chinese medicines in East Asia and diasporas [291].

\section{Materials and Methods}

A comprehensive literature search was conducted using the PubMed, Scopus, and Web of Science bibliographic databases to identify scientific reports on the psychiatric and neurological complications associated with the use of A. catechu, A. mexicana, C. aurantium, E. longifolia, L. meyenii, M. speciosa, P. ginseng, P. quinquefolius, P. johimbe, P. methysticum, P. olacoides, S. tortuosum, T. diffusa, V. africana, and $W$. somnifera. Database-specific search features with truncations (represented by an asterisk in this article) and multiple keywords (represented by quotation marks in this article) were employed. The search terms employed were addict*, anxiety, anxious, "brain disorder *", cognit *, depression, depressive, hallucin *, insomnia *, mania *, manic, mental, panic, "personality disorder ${ }^{*}$, , psychiatry *, psychosis, psychotic, or schizoph * in combination with the following terms for each plant:

- A. catechu: "Areca catechu", "areca palm", "areca nut palm", "betel palm”, "Indian nut", "Pinang palm", arecaidine, or arecoline;

- A. Mexicana: "Argemone mexicana", "Mexican poppy", "flowering thistle", sanguinarine, dihydrosanguinarine, dehydrocorydalmine, jatrorrhizine, columbamine, or oxyberberine;

- C. aurantium: "Citrus aurantium", "bitter orange", "Seville orange", "bigarade orange", or "marmalade orange";

- E. longifolia: "Eurycoma longifolia", "tongkat ali", "pasak bumi", "Malaysian ginseng”, eurycomanol, eurycomanone, or eurycomalactone;

- L. meyenii: "Lepidium meyenii", maca, or "Peruvian ginseng";

- M. speciosa: "Mitragyna speciose", kratom, biak, mitragynine, or hydroxymitragynine;

- P. ginseng and P. quinquefolius: "Panax ginseng", "Panax quinquefolius", ginseng, or ginsenoside*;

- P. johimbe: "Pausinystalia johimbe", yohimbe, ajmalicine, allo-yohimbine, corynantheine, pseudoyohimbine, raubasine, yohimbine;

- P. olacoides: "Ptychopetalum olacoides", "muira puama", or muirapuamine;

- S. tortuosum: "Sceletium tortuosum", kanna, channa, kougoed, mesembrine, mesembrenone, mesembrenol, or tortuosamine;

- T. diffusa: "Turnera diffusa", damania, or damianin;

- V. Africana: "Voacanga africana", voacamine, or voacangine;

- W. somnifera: "Withania somnifera", ashwagandha, "Indian ginseng", or "poison gooseberry".

Further studies were retrieved from the reference list of selected articles and reports from international institutions such as the World Health Organization (WHO), the US Drug Enforcement Administration (DEA), and the European Monitoring Centre for Drugs and Drug Addiction (EMCDDA). 
Records reporting the psychiatric and/or neurological adverse effects associated with the use of the selected plant species in humans were included; only articles written in English, French, and Italian were included. Databases were screened up until June 2020 and references were independently reviewed by three of the authors to determine their relevance to the present article.

\section{Conclusions}

Most of the sexual enhancers of plant origin included in this review appeared to be safe at therapeutic doses, and few psychiatric and neurological side effects were reported. Yohimbe mainly was involved in intoxication cases, but its cardiovascular toxicity is more concerning than its psychiatric and neurological adverse effects. In addition, causality was often difficult to determine, especially in case reports and self-reports, in which co-administration of other substances and herbal formulations is prevalent. Interactions with pharmaceuticals or other herbal supplements are more common and may pose a significant health threat.

The mechanisms underlying psychiatric and neurological disorders are multifaceted, often involving multiple CNS pathways and receptors, and are not fully understood. Similarly, herbal aphrodisiacs often contain multiple active ingredients with multiple mechanisms of action that are yet to be fully characterized. Consequently, the mechanisms underlying the psychiatric and neurological side effects associated with herbal aphrodisiac use is little-known.

Other sources of aphrodisiacs affecting the CNS are available, such as synthetic or semi-synthetic drugs and natural substances of animal origin, which may also induce psychiatric or neurological effects. Although aphrodisiacs are mainly obtained from plants, these substances may also be worthy of investigation. It is also important to consider that plants that do not induce psychiatric or neurological adverse effects are not necessarily harmless, and could exhibit another type of toxicity (e.g., cardiovascular, hepatic, and renal toxicity), which was not the focus of the present review.

Author Contributions: P.B. and J.C. designed the study; A.F.L.F. and F.P.B. approved the design. P.B., A.F.L.F., A.T. and J.C. collected and organized the data and drafted the manuscript. All the authors contributed to the revision of the manuscript and approved the final content. All authors have read and agreed to the published version of the manuscript.

Funding: This research received no external funding.

Conflicts of Interest: The authors declare no conflict of interest.

\section{References}

1. Leonti, M.; Casu, L. Ethnopharmacology of love. Front. Pharmacol. 2018, 9, 567. [CrossRef]

2. Giorgetti, R.; Tagliabracci, A.; Schifano, F.; Zaami, S.; Marinelli, E.; Busardò, F.P. When “Chems” Meet Sex: A Rising Phenomenon Called “ChemSex.". Curr. Neuropharmacol. 2017, 15, 762-770. [CrossRef]

3. Pyke, R.E. Sexual Performance Anxiety. Sex. Med. Rev. 2020, 8, 183-190. [CrossRef] [PubMed]

4. Boivin, J.; Bunting, L.; Collins, J.A.; Nygren, K.G. International estimates on infertility prevalence and treatment seeking: Potential need and demand for medical care. Hum. Reprod. 2007, 22, 1506-1512. [CrossRef] [PubMed]

5. Smith, J.F.; Eisenberg, M.L.; Millstein, S.G.; Nachtigall, R.D.; Shindel, A.W.; Wing, H.; Cedars, M.; Pasch, L.; Katz, P.P. The use of complementary and alternative fertility treatment in couples seeking fertility care: Data from a prospective cohort in the United States. Fertil. Steril. 2010, 93, 2169-2174. [CrossRef] [PubMed]

6. Corazza, O.; Martinotti, G.; Santacroce, R.; Chillemi, E.; Di Giannantonio, M.; Schifano, F.; Cellek, S. Sexual enhancement products for sale online: Raising awareness of the psychoactive effects of yohimbine, maca, horny goat weed, and ginkgo biloba. BioMed Res. Int. 2014, 2014, 1-13. [CrossRef]

7. Rao, N.; Spiller, H.A.; Hodges, N.L.; Chounthirath, T.; Casavant, M.J.; Kamboj, A.K.; Smith, G.A. An Increase in Dietary Supplement Exposures Reported to US Poison Control Centers. J. Med. Toxicol. 2017, 13, 227-237. [CrossRef] [PubMed]

8. Sandroni, P. Aphrodisiacs past and present: A historical review. Clin. Auton. Res. 2001, 11, $303-307$. [CrossRef] [PubMed] 
9. Guarraci, F.A.; Bolton, J.L. "Sexy stimulants": The interaction between psychomotor stimulants and sexual behavior in the female brain. Pharmacol. Biochem. Behav. 2014, 121, 53-61. [CrossRef]

10. Rot, M.A.H.; Mathew, S.J.; Charney, D.S. Neurobiological mechanisms in major depressive disorder. Can. Med. Assoc. J. 2009, 180, 305-313. [CrossRef]

11. Kato, T. Current understanding of bipolar disorder: Toward integration of biological basis and treatment strategies. Psychiatry Clin. Neurosci. 2019, 73, 526-540. [CrossRef] [PubMed]

12. Martel, J.C.; McArthur, S.G. Dopamine Receptor Subtypes, Physiology and Pharmacology: New Ligands and Concepts in Schizophrenia. Front. Pharmacol. 2020, 11, 1003. [CrossRef] [PubMed]

13. Hirao, K.; Pontone, G.M.; Smith, G.S. Molecular imaging of neuropsychiatric symptoms in Alzheimer's and Parkinson's disease. Neurosci. Biobehav. Rev. 2015, 49, 157-170. [CrossRef] [PubMed]

14. Srivatsav, A.; Balasubramanian, A.; Pathak, U.I.; Rivera-Mirabal, J.; Thirumavalavan, N.; Hotaling, J.M.; Lipshultz, L.I.; Pastuszak, A.W. Efficacy and Safety of Common Ingredients in Aphrodisiacs Used for Erectile Dysfunction: A Review. Sex. Med. Rev. 2020, 8, 431-442. [CrossRef] [PubMed]

15. Deahl, M. Betel nut-induced extrapyramidal syndrome: An unusual drug interaction. Mov. Disord. 1989, 4, 330-332. [CrossRef] [PubMed]

16. Winstock, A.R.; Trivedy, C.R.; Warnakulasuriya, S.; Peters, T.J. A dependency syndrome related to areca nut use: Some medical and psychological aspects among areca nut users in the Gujarat community in the UK. Addict. Biol. 2000, 5, 173-179. [CrossRef] [PubMed]

17. Hafeman, D.; Ahsan, H.; Islam, T.; Louis, E. Betel quid: Its tremor-producing effects in residents of Araihazar, Bangladesh. Mov. Disord. 2005, 21, 567-571. [CrossRef] [PubMed]

18. Senn, M.; Baiwog, F.; Winmai, J.; Mueller, I.; Rogerson, S.; Senn, N. Betel nut chewing during pregnancy, Madang province, Papua New Guinea. Drug Alcohol Depend. 2009, 105, 126-131. [CrossRef] [PubMed]

19. Bhat, S.J.S.; Blank, M.D.; Balster, R.L.; Nichter, M.; Nichter, M. Areca nut dependence among chewers in a South Indian community who do not also use tobacco. Addiction 2010, 105, 1303-1310. [CrossRef]

20. Mirza, S.S.; Shafique, K.; Vart, P.; Arain, M.I. Areca nut chewing and dependency syndrome: Is the dependence comparable to smoking? A cross sectional study. Subst. Abus. Treat. Prev. Policy 2011, 6, 23. [CrossRef]

21. Lee, C.H.; Chiang, S.L.; Ko, A.M.-S.; Hua, C.H.; Tsai, M.H.; Warnakulasuriya, S.; Ibrahim, S.O.; Sunarjo; Zain, R.B.; Ling, T.Y.; et al. Betel-quid dependence domains and syndrome associated with betel-quid ingredients among chewers: An Asian multi-country evidence. Addiction 2014, 109, 1194-1204. [CrossRef] [PubMed]

22. Lin, C.C.; Tamí-Maury, I.M.; Ma, W.F.; Lam, C.; Tsai, M.H.; Lin, M.T.; Li, C.I.; Liu, C.S.; Li, T.C.; Chiu, C.F.; et al. Social and Cultural Context of Betel Quid Consumption in Taiwan and Implications for Prevention and Cessation Interventions. Subst. Use Misuse 2017, 52, 646-655. [CrossRef]

23. Mateen, F.J.; Carone, M.; Tshering, L.; Dorji, C.; Dema, U.; Grundy, S.J.; Pokhrel, D.R.; Nirola, D.K. Areca catechu (palm tree) nut chewing and seizures: An observational study. Epilepsy Behav. 2017, 74, 76-80. [CrossRef]

24. Osborne, P.G.; Ko, Y.C.; Wu, M.T.; Lee, C.H. Intoxication and substance use disorder to Areca catechu nut containing betel quid: A review of epidemiological evidence, pharmacological basis and social factors influencing quitting strategies. Drug Alcohol Depend. 2017, 179, 187-197. [CrossRef] [PubMed]

25. Papke, R.L.; Bhattacharyya, I.; Hatsukami, D.K.; Moe, I.; Glatman, S. Betel Nnut (areca) and Smokeless Tobacco Use in Myanmar. Subst. Use Misuse 2020, 55, 1385-1394. [CrossRef] [PubMed]

26. Tsai, M.H.; Li, T.C.; Li, C.I.; Gritz, E.R.; Lam, C.; Chiu, C.F.; Liu, C.S.; Lai, C.C.; Hsu, W.Y.; Tamí-Maury, I.; et al. Development and preliminary validation of a mandarin Chinese language questionnaire measuring betel quid dependency among adults in Taiwan. Psychiatry Res. 2019, 271, 153-160. [CrossRef] [PubMed]

27. Sitaram, N.; Nurnberger, J.I.; Gershon, E.S.; Gillin, J.C. Cholinergic regulation of mood and REM sleep: Potential model and marker of vulnerability to affective disorder. Am. J. Psychiatry 1982, 139, 571-576. [CrossRef]

28. Nurnberger, J.I.; Jimerson, D.C.; Simmons-Alling, S.; Tamminga, C.; Nadi, N.S.; Lawrence, D.; Sitaram, N.; Gillin, J.C.; Gershon, E.S. Behavioral, physiological, and neuroendocrine responses to arecoline in normal twins and "well state" bipolar patients. Psychiatry Res. 1983, 9, 191-200. [CrossRef]

29. Dubé, S.; Kumar, N.; Ettedgui, E.; Pohl, R.; Jones, D.; Sitaram, N. Cholinergic REM induction response: Separation of anxiety and depression. Biol. Psychiatry 1985, 20, 408-418. [CrossRef] 
30. Overstreet, D.H. Selective breeding for increased cholinergic function: Development of a new animal model of depression. Biol. Psychiatry 1986, 21, 49-58. [CrossRef]

31. Tariot, P.N.; Cohen, R.M.; Welkowitz, J.A.; Sunderland, T.; Newhouse, P.A.; Murphy, D.L.; Weingartner, H. Multiple-Dose Arecoline Infusions in Alzheimer's Disease. Arch. Gen. Psychiatry 1988, 45, 901-905. [CrossRef]

32. Wager, S.; Robinson, D.; Goetz, R.; Nunes, E.; Gully, R.; Quitkin, F. Cholinergic REM sleep induction in atypical depression. Biol. Psychiatry 1990, 27, 441-446. [CrossRef] [PubMed]

33. Polinsky, R.J.; Brown, R.T.; Curras, M.T.; Baser, S.M.; Baucom, C.E.; Hooper, D.R.; Marini, A.M. Central and peripheral effects of arecoline in patients with autonomic failure. J. Neurol. Neurosurg. Psychiatry 1991, 54, 807-812. [CrossRef]

34. Gillin, J.C.; Sutton, L.; Ruiz, C.; Kelsoe, J.; Dupont, R.M.; Darko, D.; Risch, S.C.; Golshan, S.; Janowsky, D. The Cholinergic Rapid Eye Movement Induction Test With Arecoline in Depression. Arch. Gen. Psychiatry 1991, 48, 264-270. [CrossRef] [PubMed]

35. Dahl, R.E.; Ryan, N.D.; Perel, J.; Birmaher, B.; Al-Shabbout, M.; Nelson, B.; Puig-Antich, J. Cholinergic REM induction test with arecoline in depressed children. Psychiatry Res. 1994, 51, 269-282. [CrossRef]

36. Molinengo, L.; Orsetti, M.; Pastorello, B.; Scordo, I.; Ghi, P. The action of arecoline on retrieval and memory storage evaluated in the staircase maze. Neurobiol. Learn. Mem. 1995, 63, 167-173. [CrossRef] [PubMed]

37. Chau, D.T.; Rada, P.; Kosloff, R.A.; Taylor, J.L.; Hoebel, B.G. Nucleus accumbens muscarinic receptors in the control of behavioral depression: Antidepressant-like effects of local $\mathrm{m} 1$ antagonist in the porsolt swim test. Neuroscience 2001, 104, 791-798. [CrossRef] [PubMed]

38. Carvalho-Freitas, M.I.R.; Costa, M. Anxiolytic and sedative effects of extracts and essential oil from Citrus aurantium L. Biol. Pharm. Bull. 2002, 25, 1629-1633. [CrossRef] [PubMed]

39. Kamalifard, M.; Farshbaf-Khalili, A.; Namadian, M.; Ranjbar, Y.; Herizchi, S. Comparison of the Effect of Lavender and Bitter Orange on Sleep Quality in Postmenopausal Women: A Triple-Blind, Randomized, Controlled Clinical Trial. Women Health 2018, 58, 851-865. [CrossRef]

40. Farshbaf-Khalili, A.; Kamalifard, M.; Namadian, M. Comparison of the Effect of Lavender and Bitter Orange on Anxiety in Postmenopausal Women: A Triple-Blind, Randomized, Controlled Clinical Trial. Complement. Ther. Clin. Pract. 2018, 31, 132-138. [CrossRef]

41. Heydari, N.; Abootalebi, M.; Tayebi, N.; Hassanzadeh, F.; Kasraeian, M.; Emamghoreishi, M.; Akbarzadeh, M. The Effect of Aromatherapy on Mental, Physical Symptoms, and Social Functions of Females With Premenstrual Syndrome: A Randomized Clinical Trial. J. Fam. Med. Prim. Care 2019, 8, 2990-2996. [CrossRef]

42. Assanangkornchai, S.; Muekthong, A.; Sam-Angsri, N.; Pattanasattayawong, U. The use of Mitragynine speciosa ("Krathom"), an addictive plant, in Thailand. Subst. Use Misuse 2007, 42, 2145-2157. [CrossRef] [PubMed]

43. Boyer, E.W.; Babu, K.M.; Adkins, J.E.; Mccurdy, C.R.; Halpern, J.H. Self-treatment of opioid withdrawal using kratom (Mitragynia speciosa korth). Addiction 2008, 103, 1048-1050. [CrossRef] [PubMed]

44. Nelsen, J.L.; Lapoint, J.; Hodgman, M.J.; Aldous, K.M. Seizure and Coma Following Kratom (Mitragynina speciosa Korth) Exposure. J. Med. Toxicol. 2010, 6, 424-426. [CrossRef]

45. Vicknasingam, B.; Narayanan, S.; Beng, G.T.; Mansor, S.M. The informal use of ketum (Mitragyna speciosa) for opioid withdrawal in the northern states of peninsular Malaysia and implications for drug substitution therapy. Int. J. Drug Policy 2010, 21, 283-288. [CrossRef]

46. McWhirter, L.; Morris, S. A case report of inpatient detoxification after kratom (Mitragyna speciosa) dependence. Eur. Addict. Res. 2010, 16, 229-231. [CrossRef] [PubMed]

47. Ahmad, K.; Aziz, Z. Mitragyna speciosa use in the northern states of Malaysia: A cross-sectional study. J. Ethnopharmacol. 2012, 141, 446-450. [CrossRef]

48. Trakulsrichai, S.; Tongpo, A.; Sriapha, C.; Wongvisawakorn, S.; Rittilert, P.; Kaojarern, S.; Wananukul, W. Kratom Abuse in Ramathibodi Poison Center, Thailand: A Five-Year. J. Psychoact. Drugs 2012, 45, 404-408. [CrossRef]

49. Forrester, M.B. Kratom exposures reported to Texas poison centers. J. Addict. Dis. 2013, 32, $396-400$. [CrossRef] [PubMed] 
50. Saingam, D.; Assanangkornchai, S.; Geater, A.F.; Balthip, Q. Pattern and consequences of krathom (Mitragyna speciosa Korth.) use among male villagers in southern Thailand: A qualitative study. Int. J. Drug Policy 2013, 24, 351-358. [CrossRef]

51. Singh, D.; Müller, C.P.; Vicknasingam, B.K. Kratom (Mitragyna speciosa) dependence, withdrawal symptoms and craving in regular users. Drug Alcohol Depend. 2014, 139, 132-137. [CrossRef] [PubMed]

52. Swogger, M.T.; Hart, E.; Erowid, F.; Erowid, E.; Trabold, N.; Yee, K.; Parkhurst, K.A.; Priddy, B.M.; Walsh, Z. Experiences of Kratom Users: A Qualitative Analysis. J. Psychoact. Drugs 2015, 47, 360-367. [CrossRef]

53. Anwar, M.; Law, R.; Schier, J. Notes from the Field: Kratom (Mitragyna speciosa) Exposures Reported to Poison Centers-United States, 2010-2015. MMWR. Morb. Mortal. Wkly. Rep. 2016, 65, 748-749. [CrossRef] [PubMed]

54. Saingam, D.; Assanangkornchai, S.; Geater, A.F.; Lerkiatbundit, S. Factor analytical investigation of krathom (mitragyna speciosa korth.) withdrawal syndrome in Thailand. J. Psychoact. Drugs 2016, 48, 76-85. [CrossRef]

55. Buresh, M. Treatment of kratom dependence with buprenorphine-naloxone maintenance. J. Addict. Med. 2018, 12, 481-483. [CrossRef] [PubMed]

56. Singh, D.; Narayanan, S.; Müller, C.P.; Swogger, M.T.; Rahim, A.A.; Leong Bin Abdullah, M.F.I.; Vicknasingam, B.K.; Marc, T.S. Severity of Kratom (Mitragyna speciosa Korth.) Psychological Withdrawal Symptoms. J. Psychoact. Drugs 2018, 50, 445-450. [CrossRef]

57. Mackay, L.; Abrahams, R. Novel case of maternal and neonatal kratom dependence and withdrawal. Can. Fam. Physician 2018, 64, 121-122. [PubMed]

58. Murthy, P.; Clark, D. An unusual cause for neonatal abstinence syndrome. Paediatr. Child Health 2019, 24, 12-14. [CrossRef]

59. Diep, J.; Chin, D.T.; Gupta, S.; Syed, F.; Xiong, M.; Cheng, J. Kratom, an Emerging Drug of Abuse: A Case Report of Overdose and Management of Withdrawal. A A Pract. 2018, 10, 192-194. [CrossRef]

60. Tatum, W.O.; Hasan, T.F.; Coonan, E.E.; Smelick, C.P. Recurrent seizures from chronic kratom use, an atypical herbal opioid. Epilepsy Behav. Case Rep. 2018, 10, 18-20. [CrossRef] [PubMed]

61. Khazaeli, A.; Jerry, J.M.; Vazirian, M. Treatment of Kratom Withdrawal and Addiction With Buprenorphine. J. Addict. Med. 2018, 12, 493-495. [CrossRef] [PubMed]

62. Singh, D.; Narayanan, S.; Müller, C.P.; Vicknasingam, B.; Yücel, M.; Ho, E.T.W.; Hassan, Z.; Mansor, S.M. Long-Term Cognitive Effects of Kratom (Mitragyna speciosa Korth.) Use. J. Psychoact. Drugs 2019, 51, $19-27$. [CrossRef]

63. Abdullah, M.F.I.; Singh, D.; Swogger, M.T.; Rahim, A.A.; Vicknasingam, B. The prevalence of psychotic symptoms in kratom (Mitragyna speciosa Korth.) Users in Malaysia. Asian J. Psychiatr. 2019, 43, 197-201. [CrossRef]

64. Eggleston, W.; Stoppacher, R.; Suen, K.; Marraffa, J.M.; Nelson, L.S. Kratom Use and Toxicities in the United States. Pharmacotherapy 2019, 39, 775-777. [CrossRef] [PubMed]

65. Meireles, V.; Rosado, T.; Barroso, M.; Soares, S.; Gonçalves, J.; Luís, Â.; Caramelo, D.; Simão, A.; Fernández, N.; Duarte, A.; et al. Mitragyna speciosa: Clinical, Toxicological Aspects and Analysis in Biological and Non-Biological Samples. Medicines 2019, 6, 35. [CrossRef] [PubMed]

66. Saref, A.; Suraya, S.; Singh, D.; Grundmann, O.; Narayanan, S.; Swogger, M.T.; Prozialeck, W.C.; Boyer, E.; Chear, N.J.Y.; Balasingam, V. Self-reported prevalence and severity of opioid and kratom (Mitragyna speciosa korth.) side effects. J. Ethnopharmacol. 2019, 238, 111876. [CrossRef] [PubMed]

67. Stanciu, C.N.; Gnanasegaram, S.A.; Ahmed, S.; Penders, T. Kratom Withdrawal: A Systematic Review with Case Series. J. Psychoact. Drugs 2019, 51, 12-18. [CrossRef] [PubMed]

68. Schmuhl, K.K.; Gardner, S.M.; Cottrill, C.B.; Bonny, A.E. Home induction and outpatient treatment of kratom use disorder with buprenorphine-naloxone: A case report in a young adult. Subst. Abus. 2020, 41, 311-314. [CrossRef]

69. Afzal, H.; Esang, M.; Rahman, S. A Case of Kratom-induced Seizures. Cureus 2020, 12, e6588. [CrossRef]

70. Garcia-Romeu, A.; Cox, D.J.; Smith, K.E.; Dunn, K.E.; Griffiths, R.R. Kratom (Mitragyna speciosa): User demographics, use patterns, and implications for the opioid epidemic. Drug Alcohol Depend. 2020, 208, 107849. [CrossRef]

71. Singh, D.; Narayanan, S.; Suraya, S.; Saref, A.; Grundmann, O.; Prozialeck, W.C.; Corazza, O.; Swogger, M.T.; Griffin, O.; Balasingam, V. Public Perceptions toward Kratom (Mitragyna Speciosa) Use in Malaysia. J. Psychoact. Drugs 2020, 52, 282-288. [CrossRef] [PubMed] 
72. Apryani, E.; Hidayat, M.T.; Moklas, M.A.A.; Fakurazi, S.; Idayu, N.F. Effects of mitragynine from Mitragyna speciosa Korth leaves on working memory. J. Ethnopharmacol. 2010, 129, 357-360. [CrossRef] [PubMed]

73. Karinen, R.; Fosen, J.T.; Rogde, S.; Vindenes, V. An accidental poisoning with mitragynine. Forensic Sci. Int. 2014, 245, e29-e32. [CrossRef] [PubMed]

74. Yusoff, N.H.M.; Suhaimi, F.W.; Vadivelu, R.K.; Hassan, Z.; Rümler, A.; Rotter, A.; Amato, D.; Dringenberg, H.C.; Mansor, S.M.; Navaratnam, V.; et al. Abuse potential and adverse cognitive effects of mitragynine (kratom). Addict. Biol. 2016, 21, 98-110. [CrossRef]

75. Hemby, S.E.; Mcintosh, S.; Leon, F.; Cutler, S.J.; Mccurdy, C.R. Abuse liability and therapeutic potential of the Mitragyna speciosa (kratom) alkaloids mitragynine and 7-hydroxymitragynine. Addict. Biol. 2019, 24, 874-885. [CrossRef] [PubMed]

76. Hassan, Z.; Suhaimi, F.W.; Ramanathan, S.; Ling, K.H.; Effendy, M.A.; Müller, C.P.; Dringenberg, H.C. Mitragynine (Kratom) impairs spatial learning and hippocampal synaptic transmission in rats. J. Psychopharmacol. 2019, 33, 908-918. [CrossRef]

77. Vadnal, R.; Parthasarathy, L.; Parthasarathy, R. The Use of Ginseng as an Adjunct in Treatment-Resistant Depression. Nutr. Neurosci. 1998, 1, 83-85. [CrossRef]

78. Joshi, K.G.; Faubion, M.D. Mania and Psychosis Associated with St. John's Wort and Ginseng. Psychiatry (Edgmont) 2005, 2, 56-61.

79. Kennedy, D.O.; Scholey, A.B.; Wesnes, K.A. Dose dependent changes in cognitive performance and mood following acute administration of Ginseng to healthy young volunteers. Nutr. Neurosci. 2001, 4, 295-310. [CrossRef]

80. Kennedy, D.O.; Scholey, A.B.; Wesnes, K.A. Differential, dose dependent changes in cognitive performance following acute administration of a Ginkgo biloba/Panax ginseng combination to healthy young volunteers. Nutr. Neurosci. 2001, 4, 399-412. [CrossRef] [PubMed]

81. Vázquez, I.; Agüera-Ortiz, L.F. Herbal products and serious side effects: A case of ginseng-induced manic episode. Acta Psychiatr. Scand. 2002, 105, 76-77. [PubMed]

82. Hartley, D.E.; Elsabagh, S.; File, S.E. Gincosan (A combination of ginkgo biloba and panax ginseng): The effects on mood and cognition of 6 and 12 weeks' treatment in post-menopausal women. Nutr. Neurosci. 2004, 7, 325-333. [CrossRef] [PubMed]

83. Niederhofer, H. Panax ginseng may improve some symptoms of attention-deficit hyperactivity disorder. J. Diet. Suppl. 2009, 6, 22-27. [CrossRef] [PubMed]

84. Jeong, H.G.; Ko, Y.H.; Oh, S.Y.; Han, C.; Kim, T.; Joe, S.H. Effect of Korean Red Ginseng as an adjuvant treatment for women with residual symptoms of major depression. Asia Pac. Psychiatry 2015, 7, 330-336. [CrossRef] [PubMed]

85. Norelli, L.J.; Xu, C. Manic psychosis associated with Ginseng: A report of two cases and discussion of the literature. J. Diet. Suppl. 2015, 12, 119-125. [CrossRef] [PubMed]

86. Yennurajalingam, S.; Reddy, A.; Tannir, N.M.; Chisholm, G.B.; Lee, R.T.; Lopez, G.; Escalante, C.P.; Manzullo, E.F.; Hume, S.F.; Williams, J.L.; et al. High-Dose Asian Ginseng (Panax Ginseng) for Cancer-Related Fatigue: A Preliminary Report. Integr. Cancer Ther. 2015, 14, 419-427. [CrossRef]

87. Yadav, P.; Stigall, K.; Johnson, H.E.; Rayapati, A.O.; Chopra, N. Functional foods: How functional are they? A case report of supplement-induced psychosis. Int. J. Psychiatry Med. 2016, 51, 479-485. [CrossRef]

88. Bostock, E.; Kirkby, K.; Garry, M.; Taylor, B.; Hawrelak, J.A. Mania associated with herbal medicines, other than cannabis: A systematic review and quality assessment of case reports. Front. Psychiatry 2018, 9, 208. [CrossRef] [PubMed]

89. Farnia, V.; Alikhani, M.; Ebrahimi, A.; Golshani, S.; Bahmani, D.S.; Brand, S. Ginseng treatment improves the sexual side effects of methadone maintenance treatment. Psychiatry Res. 2019, 276, 142-150. [CrossRef] [PubMed]

90. Görgülü, S. Manic Episode Associated with Ginseng: A Case Report. Int. J. Med. Rev. Case Rep. 2020, 4, 111-113. [CrossRef]

91. Lee, J.; Lee, A.; Kim, J.-H.; Shin, Y.M.; Kim, S.-J.; Cho, W.D.; Lee, S.I. Effect of omega-3 and Korean red ginseng on children with attention deficit hyperactivity disorder: An open-label pilot study. Clin. Psychopharmacol. Neurosci. 2020, 18, 75-80. [CrossRef] [PubMed] 
92. Jones, B.D.; Runikis, A.M. Interaction of ginseng with phenelzine. J. Clin. Psychopharmacol. 1987, 7, $201-202$. [CrossRef] [PubMed]

93. Lyon, M.R.; Cline, J.C.; De Zepetnek, J.T.; Shan, J.J.; Pang, P.; Benishin, C. Effect of the herbal extract combination Panax quinquefolium and Ginkgo biloba on attention-deficit hyperactivity disorder: A pilot study. J. Psychiatry Neurosci. 2001, 26, 221-228. [PubMed]

94. Ma, H.; Sullivan-Halley, J.; Smith, A.W.; Neuhouser, M.L.; Alfano, C.M.; Meeske, K.; George, S.M.; McTiernan, A.; McKean-Cowdin, R.; Baumgartner, K.B.; et al. Estrogenic botanical supplements, health-related quality of life, fatigue, and hormone-related symptoms in breast cancer survivors: A HEAL study report. BMC Complement. Altern. Med. 2011, 11, 109. [CrossRef]

95. Papeschi, R.; Sourkers, T.L.; Youdim, M.B. The effect of yohimbine on brain serotonin metabolism, motor behavior and body temperature of the rat. Eur. J. Pharmacol. 1971, 15, 318-326. [CrossRef]

96. MacKintosh, C.G.; Van Reenen, G. Comparison of yohimbine, 4-aminopyridine and doxapram antagonism of xylazine sedation in deer (Cervus elaphus). N. Z. Vet. J. 1984, 32, 181-184. [CrossRef] [PubMed]

97. Price, L.H.; Charney, D.S.; Heninger, G.R. Three cases of manic symptoms following yohimbine administration. Am. J. Psychiatry 1984, 141, 1267-1268. [CrossRef]

98. Charney, D.S.; Heninger, G.R.; Breier, A. Noradrenergic Function in Panic Anxiety. Arch. Gen. Psychiatry 1984, 41, 751-763. [CrossRef]

99. Linden, C.H.; Vellman, W.P.; Rumack, B. Yohimbine: A new street drug. Ann. Emerg. Med. 1985, 14, $1002-1004$. [CrossRef]

100. Charney, S.; Woods, S.W.; Goodman, K.; Heninger, R. Neurobiological Mechanisms of Panic Anxiety: Biochemical and Behavioral Correlates of Yohimbine-Induced Panic Attacks. Am. J. Psychiatry 1987, 144, 1030-1036. [CrossRef]

101. Johnston, A.L.; Baldwin, H.A.; File, S.E. Measures of anxiety and stress in the rat following chronic treatment with yohimbine. J. Psychopharmacol. 1988, 2, 33-38. [CrossRef] [PubMed]

102. Heninger, G.R.; Charney, D.S.; Price, L.H. alpha 2-Adrenergic receptor sensitivity in depression. The plasma MHPG, behavioral, and cardiovascular responses to yohimbine. Arch. Gen. Psychiatry 1988, 45, 718-726. [CrossRef] [PubMed]

103. Dilsaver, S.C.; Davidson, R.K. Chronic treatment with amitriptyline produces subsensitivity to the hypothermic effects of yohimbine. Prog. Neuro-Psychopharmacology Biol. Psychiatry 1989, 13, 211-215. [CrossRef]

104. Rosenblum, L.A.; Coplan, J.D.; Friedman, S.; Bassoff, T. Dose-response effects of oral yohimbine in unrestrained primates. Biol. Psychiatry 1991, 29, 647-657. [CrossRef]

105. Charney, D.S.; Woods, S.W.; Krystal, J.H.; Nagy, L.M.; Heninger, G.R. Noradrenergic neuronal dysregulation in panic disorder: The effects of intravenous yohimbine and clonidine in panic disorder patients. Acta Psychiatr. Scand. 1992, 86, 273-282. [CrossRef]

106. Friesen, K.; Palatnick, W.; Tenenbein, M. Benign course after massive ingestion of yohimbine. J. Emerg. Med. 1993, 11, 287-288. [CrossRef]

107. Kollias-Baker, C.A.; Court, M.H.; Williams, L.L. Influence of yohimbine and tolazoline on the cardiovascular, respiratory, and sedative effects of xylazine in the horse. J. Vet. Pharmacol. Ther. 1993, 16, 350-358. [CrossRef] [PubMed]

108. Wooten, V. Effectiveness of yohimbine in treating narcolepsy. South. Med. J. 1994, 87, 1065-1066. [CrossRef] [PubMed]

109. Southwick, S.M.; Morgan, C.A., III; Charney, D.S.; High, J.R. Yohimbine use in a natural setting: Effects on posttraumatic stress disorder. Biol. Psychiatry 1999, 46, 442-444. [CrossRef]

110. Cameron, O.G.; Zubieta, J.K.; Grunhaus, L.; Minoshima, S. Effects of yohimbine on cerebral blood flow, symptoms, and physiological functions in humans. Psychosom. Med. 2000, 62, 549-559. [CrossRef]

111. Morales, L.; Perez-Garcia, C.; Alguacil, L.F. Effects of yohimbine on the antinociceptive and place conditioning effects of opioid agonists in rodents. Br. J. Pharmacol. 2001, 133, 172-178. [CrossRef] [PubMed]

112. Matsunaga, T.; Tsukada, H.; Nishiyama, S.; Sekine, Y.; Kakiuchi, T.; Iyo, M.; Mori, N. Yohimbine increases the binding potential for $[11 \mathrm{C}]$ flumazenil in the monkey brain. J. Neural Transm. 2001, 108, 1375-1382. [CrossRef] [PubMed] 
113. Stine, S.M.; Southwick, S.M.; Petrakis, I.L.; Kosten, T.R.; Charney, D.S.; Krystal, J.H. Yohimbine-induced withdrawal and anxiety symptoms in opioid-dependent patients. Biol. Psychiatry 2002, 51, 642-651. [CrossRef]

114. Shepard, J.D.; Bossert, J.M.; Liu, S.Y.; Shaham, Y. The anxiogenic drug yohimbine reinstates methamphetamine seeking in a rat model of drug relapse. Biol. Psychiatry 2004, 55, 1082-1089. [CrossRef]

115. Lee, B.; Tiefenbacher, S.; Platt, D.M.; Spealman, R.D. Pharmacological blockade of $\alpha 2$-adrenoceptors induces reinstatement of cocaine-seeking behavior in squirrel monkeys. Neuropsychopharmacology 2004, 29, 686-693. [CrossRef]

116. Ehlert, U.; Erni, K.; Hebisch, G.; Nater, U. Salivary $\alpha$-amylase levels after yohimbine challenge in healthy men. J. Clin. Endocrinol. Metab. 2006, 91, 5130-5133. [CrossRef]

117. Keedy, S.K.; Connor, M.M.; Beenken, B.; Dorflinger, J.; Abel, M.; Erwin, R.J. Noradrenergic antagonism of the P13 and N40 components of the rat auditory evoked potential. Psychopharmacology 2007, 190, 117-125. [CrossRef]

118. Giampreti, A.; Lonati, D.; Locatelli, C.; Rocchi, L.; Campailla, M.T. Acute neurotoxicity after yohimbine ingestion by a body builder. Clin. Toxicol. 2009, 47, 827-829. [CrossRef]

119. Powers, M.B.; Smits, J.A.J.; Otto, M.W.; Sanders, C.; Emmelkamp, P.M.G. Facilitation of fear extinction in phobic participants with a novel cognitive enhancer: A randomized placebo controlled trial of yohimbine augmentation. J. Anxiety Disord. 2009, 23, 350-356. [CrossRef]

120. Banna, K.M.; Back, S.E.; Do, P.; See, R.E. Yohimbine stress potentiates conditioned cue-induced reinstatement of heroin-seeking in rats. Behav. Brain Res. 2010, 208, 144-148. [CrossRef]

121. Sommer, M.; Braumann, M.; Althoff, T.; Backhaus, J.; Kordon, A.; Junghanns, K.; Ehrenthal, D.; Bartmann, U.; Hohagen, F.; Broocks, A. Psychological and neuroendocrine responses to social stress and to the administration of the alpha-2-receptor antagonist, yohimbine, in highly trained endurance athletes in comparison to untrained healthy controls. Pharmacopsychiatry 2011, 44, 129-134. [CrossRef] [PubMed]

122. Umhau, J.C.; Schwandt, M.L.; Usala, J.; Geyer, C.; Singley, E.; George, D.T.; Heilig, M. Pharmacologically induced alcohol craving in treatment seeking alcoholics correlates with alcoholism severity, but is insensitive to acamprosate. Neuropsychopharmacology 2011, 36, 1178-1186. [CrossRef] [PubMed]

123. Berman, S.; Suyenobu, B.; Naliboff, B.D.; Bueller, J.; Stains, J.; Wong, H.; Mandelkern, M.; Fitzgerald, L.; Ohning, G.; Gupta, A.; et al. Evidence for alterations in central noradrenergic signaling in irritable bowel syndrome. Neuroimage 2012, 63, 1854-1863. [CrossRef]

124. Li, S.; Zou, S.; Coen, K.; Funk, D.; Shram, M.J.; Lê, A.D. Sex differences in yohimbine-induced increases in the reinforcing efficacy of nicotine in adolescent rats. Addict. Biol. 2014, 19, 156-164. [CrossRef] [PubMed]

125. Lê, A.D.; Funk, D.; Coen, K.; Li, Z.; Shaham, Y. Role of corticotropin-releasing factor in the median raphe nucleus in yohimbine-induced reinstatement of alcohol seeking in rats. Addict. Biol. 2013, 18, 448-451. [CrossRef] [PubMed]

126. Anderson, C.; Anderson, D.; Harre, N.; Wade, N. Case study: Two fatal case reports of acute yohimbine intoxication. J. Anal. Toxicol. 2013, 37, 611-614. [CrossRef]

127. Stopponi, S.; De Guglielmo, G.; Somaini, L.; Cippitelli, A.; Cannella, N.; Kallupi, M.; Ubaldi, M.; Heilig, M.; Demopulos, G.; Gaitanaris, G.; et al. Activation of PPAR c by Pioglitazone Potentiates the Effects of Naltrexone on Alcohol Drinking and Relapse in msP Rats. Alcohol. Clin. Exp. Res. 2013, 37, 1351-1360. [CrossRef]

128. Moran-Santa Maria, M.M.; McRae-Clark, A.; Baker, N.L.; Ramakrishnan, V.; Brady, K.T. Yohimbine administration and cue-reactivity in cocaine-dependent individuals. Psychopharmacology 2014, 231, 4157-4165. [CrossRef]

129. Li, Q.; Lin, J.; Zhang, Y.; Liu, X.; Chen, X.Q.; Xu, M.Q.; He, L.; Li, S.; Guo, N. Differential behavioral responses of zebrafish larvae to yohimbine treatment. Psychopharmacology 2015, 232, 197-208. [CrossRef]

130. Ball, K.T.; Jarsocrak, H.; Hyacinthe, J.; Lambert, J.; Lockowitz, J.; Schrock, J. Yohimbine reinstates extinguished 3,4-methylenedioxymethamphetamine (MDMA; ecstasy) seeking in rats with prior exposure to chronic yohimbine. Behav. Brain Res. 2015, 294, 1-6. [CrossRef]

131. Vo, L.; Hood, S.; Drummond, P.D. Involvement of Opioid Receptors and $\alpha$ 2-Adrenoceptors in Inhibitory Pain Modulation Processes: A Double-Blind Placebo-Controlled Crossover Study. J. Pain 2016, 17, 1164-1173. [CrossRef] [PubMed] 
132. Moran-Santa Maria, M.M.; Baker, N.L.; McRae-Clark, A.L.; Prisciandaro, J.J.; Brady, K.T. Effects of yohimbine and drug cues on impulsivity and attention in cocaine-dependent men and women and sex-matched controls. Drug Alcohol Depend. 2016, 162, 56-63. [CrossRef] [PubMed]

133. Kluen, L.M.; Agorastos, A.; Wiedemann, K.; Schwabe, L. Noradrenergic Stimulation Impairs Memory Generalization in Women. J. Cogn. Neurosci. 2017, 29, 1279-1291. [CrossRef] [PubMed]

134. Vo, L.; Drummond, P.D. Effect of combined opioid receptor and $\alpha 2$-adrenoceptor blockade on anxiety and electrically evoked startle responses. J. Psychopharmacol. 2017, 31, 722-729. [CrossRef]

135. Herman, A.M.; Critchley, H.D.; Duka, T. The impact of Yohimbine-induced arousal on facets of behavioural impulsivity. Psychopharmacology 2019, 236, 1783-1795. [CrossRef]

136. Prescott, J.; Jamieson, D.; Emdur, N.; Duffield, P. Acute effects of kava on measures of cognitive performance, physiological function and mood. Drug Alcohol Rev. 1993, 12, 49-57. [CrossRef]

137. Wheatley, D. Stress-induced insomnia treated with kava and valerian: Singly and in combination. Hum. Psychopharmacol. 2001, 16, 353-356. [CrossRef]

138. Connor, K.M.; Davidson, J.R.; Churchill, L.E. Adverse-Effect Profile of Kava. CNS Spectr. 2001, 6, 848-853. [CrossRef]

139. Meseguer, E.; Taboada, R.; Sánchez, V.; Mena, M.A.; Campos, V.; García De Yébenes, J. Life-threatening parkinsonism induced by kava-kava. Mov. Disord. 2002, 17, 195-196. [CrossRef]

140. Gastpar, M.; Klimm, H.D. Treatment of anxiety, tension and restlessness states with Kava special extract WS ${ }^{\circledR}$ 1490 in general practice: A randomized placebo-controlled double-blind multicenter trial. Phytomedicine 2003, 10, 631-639. [CrossRef]

141. Cairney, S.; Maruff, P.; Clough, A.R.; Collie, A.; Currie, J.; Currie, B.J. Saccade and cognitive impairment associated with kava intoxication. Hum. Psychopharmacol. 2003, 18, 525-533. [CrossRef] [PubMed]

142. Cagnacci, A.; Arangino, S.; Renzi, A.; Zanni, A.L.; Malmusi, S.; Volpe, A. Kava-Kava administration reduces anxiety in perimenopausal women. Maturitas 2003, 44, 103-109. [CrossRef] [PubMed]

143. Shinomiya, K.; Inoue, T.; Utsu, Y.; Tokunaga, S.; Masuoka, T.; Ohmori, A.; Kamei, C. Effects of kava-kava extract on the sleep-wake cycle in sleep-disturbed rats. Psychopharmacology 2005, 180, 564-569. [CrossRef] [PubMed]

144. Perez, J.; Holmes, J.F. Altered mental status and ataxia secondary to acute Kava ingestion. J. Emerg. Med. 2005, 28, 49-51. [CrossRef] [PubMed]

145. Sarris, J.; Kavanagh, D.J.; Deed, G.; Bone, K.M. St. John's wort and Kava in treating major depressive disorder with comorbid anxiety: A randomised double-blind placebo-controlled pilot trial. Hum. Psychopharmacol. 2009, 24, 41-48. [CrossRef]

146. Sarris, J.; Stough, C.; Teschke, R.; Wahid, Z.T.; Bousman, C.A.; Murray, G.; Savage, K.M.; Mouatt, P.; Ng, C.; Schweitzer, I. Kava for the treatment of generalized anxiety disorder RCT: Analysis of adverse reactions, liver function, addiction, and sexual effects. Phyther. Res. 2013, 27, 1723-1728. [CrossRef]

147. Sarris, J.; Stough, C.; Bousman, C.A.; Wahid, Z.T.; Murray, G.; Teschke, R.; Savage, K.M.; Dowell, A.; $\mathrm{Ng}$, C.; Schweitzer, I. Kava in the treatment of generalized anxiety disorder: A double-blind, randomized, placebo-controlled study. J. Clin. Psychopharmacol. 2013, 33, 643-648. [CrossRef] [PubMed]

148. Malhotra, N.; Starkey, N.J.; Charlton, S.G. Driving under the influence of drugs: Perceptions and attitudes of New Zealand drivers. Accid. Anal. Prev. 2017, 106, 44-52. [CrossRef]

149. Wang, D.; Yang, L.E.; Wang, J.; Hu, G.; Liu, Z.Y.; Yan, D.; Serikuly, N.; Alpyshov, E.T.; Demin, K.A.; Galstyan, D.S.; et al. Behavioral and physiological effects of acute and chronic kava exposure in adult zebrafish. Neurotoxicol. Teratol. 2020, 79, 106881. [CrossRef]

150. Fragoulis, A.; Siegl, S.; Fendt, M.; Jansen, S.; Soppa, U.; Brandenburg, L.O.; Pufe, T.; Weis, J.; Wruck, C.J. Oral administration of methysticin improves cognitive deficits in a mouse model of Alzheimer's disease. Redox Biol. 2017, 12, 843-853. [CrossRef]

151. Da Silva, A.L.; Bardini, S.; Nunes, D.S.; Elisabetsky, E. Anxiogenic properties of Ptychopetalum olacoides Benth. (Marapuama). Phyther. Res. 2002, 16, 223-226. [CrossRef] [PubMed]

152. Da Silva, A.L.; Da Silva Martins, B.; Linck, V.D.M.; Herrmann, A.P.; Mai, N.; Nunes, D.S.; Elisabetsky, E. MK801- and scopolamine-induced amnesias are reversed by an Amazonian herbal locally used as a "brain tonic.". Psychopharmacology 2009, 202, 165-172. [CrossRef] [PubMed] 
153. Chiu, S.; Gericke, N.; Farina-Woodbury, M.; Badmaev, V.; Raheb, H.; Terpstra, K.; Antongiorgi, J.; Bureau, Y.; Cernovsky, Z.; Hou, J.; et al. Proof-of-concept randomized controlled study of cognition effects of the proprietary extract sceletium tortuosum (Zembrin) targeting phosphodiesterase-4 in cognitively healthy subjects: Implications for Alzheimer's dementia. Evidence-Based Complement. Altern. Med. 2014, 2014, 682014. [CrossRef]

154. Huang, Y.J.; Jiann, B.P. Association of Areca Nut Chewing With Risk of Erectile Dysfunction. Sex. Med. 2017, 5, e163-e168. [CrossRef] [PubMed]

155. Bales, A.; Peterson, M.J.; Ojha, S.; Upadhaya, K.; Adhikari, B.; Barrett, B. Associations between betel nut (Areca catechu) and symptoms of schizophrenia among patients in Nepal: A longitudinal study. Psychiatry Res. 2009, 169, 203-211. [CrossRef] [PubMed]

156. Chu, N.S. Neurological aspects of areca and betel chewing. Addict. Biol. 2002, 7, 111-114. [CrossRef] [PubMed]

157. Lo Faro, A.F.; Di Trana, A.; La Maida, N.; Tagliabracci, A.; Giorgetti, R.; Busardò, F.P. Biomedical analysis of New Psychoactive Substances (NPS) of natural origin. J. Pharm. Biomed. Anal. 2020, 179, 112945. [CrossRef]

158. Norton, S.A. Betel: Consumption and consequences. J. Am. Acad. Dermatol. 1998, 38, 81-88. [CrossRef] [PubMed]

159. Gupta, P.C.; Warnakulasuriya, S. Global epidemiology of areca nut usage. Addict. Biol. 2002, 7, 77-83. [CrossRef]

160. Agostini-Costa, T. da S. Bioactive compounds and health benefits of some palm species traditionally used in Africa and the Americas-A review. J. Ethnopharmacol. 2018, 224, 202-229. [CrossRef]

161. Srimany, A.; George, C.; Naik, H.R.; Pinto, D.G.; Chandrakumar, N.; Pradeep, T. Developmental patterning and segregation of alkaloids in areca nut (seed of Areca catechu) revealed by magnetic resonance and mass spectrometry imaging. Phytochemistry 2016, 125, 35-42. [CrossRef] [PubMed]

162. Peng, W.; Liu, Y.J.; Wu, N.; Sun, T.; He, X.Y.; Gao, Y.X.; Wu, C.J. Areca catechu L. (Arecaceae): A review of its traditional uses, botany, phytochemistry, pharmacology and toxicology. J. Ethnopharmacol. 2015, 164, 340-356. [CrossRef]

163. Liu, Y.J.; Peng, W.; Hu, M.B.; Xu, M.; Wu, C.J. The pharmacology, toxicology and potential applications of arecoline: A review. Pharm. Biol. 2016, 54, 2753-2760. [CrossRef] [PubMed]

164. Gheddar, L.; Ricaut, F.X.; Ameline, A.; Brucato, N.; Tsang, R.; Leavesley, M.; Raul, J.S.; Kintz, P. Testing for Betel Nut Alkaloids in Hair of Papuans Abusers using UPLC-MS/MS and UPLC-Q-Tof-MS. J. Anal. Toxicol. 2020, 44, 41-48. [CrossRef] [PubMed]

165. Gupta, A.K.; Tulsyan, S.; Thakur, N.; Sharma, V.; Sinha, D.N.; Mehrotra, R. Chemistry, metabolism and pharmacology of carcinogenic alkaloids present in areca nut and factors affecting their concentration. Regul. Toxicol. Pharmacol. 2020, 110, 104548. [CrossRef] [PubMed]

166. Salehi, B.; Konovalov, D.A.; Fru, P.; Kapewangolo, P.; Peron, G.; Ksenija, M.S.; Cardoso, S.M.; Pereira, O.R.; Nigam, M.; Nicola, S.; et al. Areca catechu-From farm to food and biomedical applications. Phyther. Res. 2020, 34, 2140-2158. [CrossRef]

167. Horenstein, N.A.; Quadri, M.; Stokes, C.; Shoaib, M.; Papke, R.L. Cracking the betel nut: Cholinergic activity of areca alkaloids and related compounds. Nicotine Tob. Res. 2019, 21, 805-812. [CrossRef]

168. Thiele, A. Muscarinic Signaling in the Brain. Annu. Rev. Neurosci. 2013, 36, 271-294. [CrossRef]

169. Coppola, M.; Mondola, R. Potential action of betel alkaloids on positive and negative symptoms of schizophrenia: A review. Nord. J. Psychiatry 2012, 66, 73-78. [CrossRef]

170. Meltzer, L.T.; Rosecrans, J.A. Discriminative stimulus properties of arecoline: A new approach for studying central muscarinic receptors. Psychopharmacology 1981, 75, 383-387. [CrossRef]

171. Avery, E.E.; Baker, L.D.; Asthana, S. Potential Role of Muscarinic Agonists in Alzheimer's Disease. Drugs Aging 1997, 11, 450-459. [CrossRef] [PubMed]

172. Chandradasa, M.; Rathnayake, L. Socio-cultural and neurobiological perspectives of betel nut chewing in schizophrenia. Asian J. Psychiatr. 2018, 37, 38-39. [CrossRef] [PubMed]

173. Kuruppuarachchi, K.; Williams, S. Betel use and schizophrenia. Br. J. Psychiatry 2003, 182, 455. [CrossRef]

174. Sullivan, R.J.; Andres, S.; Otto, C.; Miles, W.; Kydd, R. The Effects of an Indigenous Muscarinic Drug, Betel Nut (Areca catechu), on the Symptoms of Schizophrenia: A Longitudinal Study in Palau, Micronesia. Am. J. Psychiatry 2007, 164, 670-673. [CrossRef] [PubMed] 
175. Moran, S.P.; Maksymetz, J.; Conn, P.J. Targeting Muscarinic Acetylcholine Receptors for the Treatment of Psychiatric and Neurological Disorders. Trends Pharmacol. Sci. 2019, 40, 1006-1020. [CrossRef] [PubMed]

176. Chu, N.S. Effects of Betel chewing on the central and autonomic nervous systems. J. Biomed. Sci. 2001, 8, 229-236. [CrossRef]

177. Molinengo, L.; Cassone, M.C.; Orsetti, M. Action of arecoline on the levels of acetylcholine, norepinephrine and dopamine in the mouse central nervous system. Pharmacol. Biochem. Behav. 1986, 24, 1801-1803. [CrossRef]

178. Manzanares, J.; Julian, M.; Carrascosa, A. Role of the Cannabinoid System in Pain Control and Therapeutic Implications for the Management of Acute and Chronic Pain Episodes. Curr. Neuropharmacol. 2006, 4, $239-257$. [CrossRef]

179. Garg, A.; Chaturvedi, P.; Gupta, P.C. A review of the systemic adverse effects of areca nut or betel nut. Indian J. Med. Paediatr. Oncol. 2014, 35, 3-9. [CrossRef]

180. Boucher, B.J.; Mannan, N. Metabolic effects of the consumption of Areca catechu. Addict. Biol. 2002, 7, 103-110. [CrossRef]

181. Johnston, G.; Krogsgaard-Larsen, P.; Stephanson, A. Betel nut constituents as inhibitors of gamma-aminobutyric acid uptake. Nature 1975, 258, 627-628. [CrossRef] [PubMed]

182. Lodge, D.; Johnston, G.A.R.; Curtis, D.R.; Brand, S.J. Effects of the Areca nut constituents arecaidine and guvacine on the action of GABA in the cat central nervous system. Brain Res. 1977, 136, 513-522. [CrossRef]

183. Volgin, A.D.; Bashirzade, A.; Amstislavskaya, T.G.; Yakovlev, O.A.; Demin, K.A.; Ho, Y.J.; Wang, D.; Shevyrin, V.A.; Yan, D.; Tang, Z.; et al. DARK Classics in Chemical Neuroscience: Arecoline. ACS Chem. Neurosci. 2019, 10, 2176-2185. [CrossRef]

184. Wu, M.; Fang, M.; Hu, Y.; Wang, X. Four types of traditional Chinese medicine inducing epileptic seizures. Seizure 2012, 21, 311-315. [CrossRef] [PubMed]

185. Shih, Y.T.; Chen, P.S.; Wu, C.H.; Tseng, Y.T.; Wu, Y.C.; Lo, Y.C. Arecoline, a major alkaloid of the areca nut, causes neurotoxicity through enhancement of oxidative stress and suppression of the antioxidant protective system. Free Radic. Biol. Med. 2010, 49, 1471-1479. [CrossRef] [PubMed]

186. Mannucci, C.; Calapai, F.; Cardia, L.; Inferrera, G.; D’Arena, G.; Di Pietro, M.; Navarra, M.; Gangemi, S.; Spagnolo, E.V.; Calapai, G. Clinical pharmacology of citrus aurantium and citrus sinensis for the treatment of anxiety. Evid.-Based Complement. Altern. Med. 2018, 2018, 3624094. [CrossRef] [PubMed]

187. Dosoky, N.S.; Setzer, W.N. Biological activities and safety of citrus spp. Essential oils. Int. J. Mol. Sci. 2018, 19, 1966. [CrossRef] [PubMed]

188. Moraes, T.M.; Kushima, H.; Moleiro, F.C.; Santos, R.C.; Rocha, L.R.M.; Marques, M.O.; Vilegas, W.; Hiruma-Lima, C.A. Effects of limonene and essential oil from Citrus aurantium on gastric mucosa: Role of prostaglandins and gastric mucus secretion. Chem. Biol. Interact. 2009, 180, 499-505. [CrossRef]

189. Stohs, S.J. Safety, Efficacy, and Mechanistic Studies Regarding Citrus aurantium (Bitter Orange) Extract and p-Synephrine. Phyther. Res. 2017, 31, 1463-1474. [CrossRef]

190. Suntar, I.; Khan, H.; Patel, S.; Celano, R.; Rastrelli, L. An overview on Citrus aurantium L.: Its functions as food ingredient and therapeutic agent. Oxid. Med. Cell. Longev. 2018, 2018, 7864269. [CrossRef]

191. Teneva, D.; Denkova-Kostova, R.; Goranov, B.; Hristova-Ivanova, Y.; Slavchev, A.; Denkova, Z.; Kostov, G. Chemical composition, antioxidant activity and antimicrobial activity of essential oil from Citrus aurantium L zest against some pathogenic microorganisms. Z. Naturforsch. C. J. Biosci. 2019, 74, 105-111. [CrossRef]

192. Tejada, S.; Pinya, S.; Martorell, M.; Capó, X.; Tur, J.A.; Pons, A.; Sureda, A. Potential Anti-inflammatory Effects of Hesperidin from the Genus Citrus. Curr. Med. Chem. 2018, 25, 4929-4945. [CrossRef]

193. Wolffenbüttel, A.N.; Zamboni, A.; Becker, G.; dos Santos, M.K.; Borille, B.T.; de Cássia Mariotti, K.; Fagundes, A.C.; de Oliveira Salomón, J.L.; Coelho, V.R.; Ruiz, L.V.; et al. Citrus essential oils inhalation by mice: Behavioral testing, GCMS plasma analysis, corticosterone, and melatonin levels evaluation. Phyther. Res. 2018, 32, 160-169. [CrossRef]

194. González-Mas, M.C.; Rambla, J.L.; López-Gresa, M.P.; Amparo Blázquez, M.; Granell, A. Volatile compounds in citrus essential oils: A comprehensive review. Front. Plant Sci. 2019, 10, 12. [CrossRef]

195. Mahato, N.; Sharma, K.; Koteswararao, R.; Sinha, M.; Baral, E.R.; Cho, M.H. Citrus essential oils: Extraction, authentication and application in food preservation. Crit. Rev. Food Sci. Nutr. 2019, 59, 611-625. [CrossRef] 
196. Escamilla-García, M.; Calderón-Domínguez, G.; Chanona-Pérez, J.J.; Mendoza-Madrigal, A.G.; Di Pierro, P.; García-Almendárez, B.E.; Amaro-Reyes, A.; Regalado-González, C. Physical, structural, barrier, and antifungal characterization of chitosan-zein edible films with added essential oils. Int. J. Mol. Sci. 2017, 18, 2370. [CrossRef] [PubMed]

197. Moslemi, F.; Alijaniha, F.; Naseri, M.; Kazemnejad, A.; Charkhkar, M.; Heidari, M.R. Citrus aurantium Aroma for Anxiety in Patients with Acute Coronary Syndrome: A Double-Blind Placebo-Controlled Trial. J. Altern. Complement. Med. 2019, 25, 833-839. [CrossRef] [PubMed]

198. de Sousa, D.P.; de Almeida Soares Hocayen, P.; Andrade, L.N.; Andreatini, R. A systematic review of the anxiolytic-like effects of essential oils in animal models. Molecules 2015, 20, 18620-18660. [CrossRef]

199. Costa, C.A.R.A.; Cury, T.C.; Cassettari, B.O.; Takahira, R.K.; Flório, J.C.; Costa, M. Citrus aurantium L. essential oil exhibits anxiolytic-like activity mediated by 5-HT1A-receptors and reduces cholesterol after repeated oral treatment. BMC Complement. Altern. Med. 2013, 13, 42. [CrossRef] [PubMed]

200. Akhlaghi, M.; Shabanian, G.; Rafieian-Kopaei, M.; Parvin, N.; Saadat, M.; Akhlaghi, M. Citrus Aurantium Blossom and Preoperative Anxiety. Rev. Bras. Anestesiol. 2011, 61, 702-712. [CrossRef]

201. Bahr, T.A.; Rodriguez, D.; Beaumont, C.; Allred, K. The effects of various essential oils on epilepsy and acute seizure: A systematic review. Evid. Based Complement. Altern. Med. 2019, 2019, 6216745. [CrossRef] [PubMed]

202. Komiya, M.; Takeuchi, T.; Harada, E. Lemon oil vapor causes an anti-stress effect via modulating the 5-HT and DA activities in mice. Behav. Brain Res. 2006, 172, 240-249. [CrossRef]

203. Ghiasi, A.; Bagheri, L.; Haseli, A. A Systematic Review on the Anxiolytic Effect of Aromatherapy during the First Stage of Labor. J. Caring Sci. 2019, 8, 51-60. [CrossRef] [PubMed]

204. Jabri Karoui, I.; Marzouk, B. Characterization of bioactive compounds in Tunisian bitter orange (Citrus aurantium L.) peel and juice and determination of their antioxidant activities. Biomed Res. Int. 2013, 2013, 345415. [CrossRef]

205. Hansen, D.K.; George, N.I.; White, G.E.; Abdel-Rahman, A.; Pellicore, L.S.; Fabricant, D. Cardiovascular toxicity of Citrus aurantium in exercised rats. Cardiovasc. Toxicol. 2013, 13, 208-219. [CrossRef]

206. Brown, A.C. Heart Toxicity Related to Herbs and Dietary Supplements: Online Table of Case Reports. Part 4 of 5. J. Diet. Suppl. 2018, 15, 516-555. [CrossRef] [PubMed]

207. Bae, K.; ji Kwon, N.; Han, E. A review on the abuse of three NPS (synthetic cannabinoids, kratom, poppers) among youths in Asia. Forensic Sci. Int. 2018, 292, 45-49. [CrossRef]

208. Singh, D.; Müller, C.P.; Vicknasingam, B.K.; Mansor, S.M. Social Functioning of Kratom (Mitragyna speciosa) Users in Malaysia. J. Psychoact. Drugs 2015, 47, 125-131. [CrossRef]

209. Brown, P.N.; Lund, J.A.; Murch, S.J. A botanical, phytochemical and ethnomedicinal review of the genus Mitragyna korth: Implications for products sold as kratom. J. Ethnopharmacol. 2017, 202, 302-325. [CrossRef]

210. Prozialeck, W.C. Update on the pharmacology and legal status of Kratom. J. Am. Osteopath. Assoc. 2016, 116, 802-809. [CrossRef]

211. Matsumoto, K.; Horie, S.; Ishikawa, H.; Takayama, H.; Aimi, N.; Ponglux, D.; Watanabe, K. Antinociceptive effect of 7-hydroxymitragynine in mice: Discovery of an orally active opioid analgesic from the Thai medicinal herb Mitragyna speciosa. Life Sci. 2004, 74, 2143-2155. [CrossRef] [PubMed]

212. Yamamoto, L.T.; Horie, S.; Takayama, H.; Aimi, N.; Sakai, S.I.; Yano, S.; Shan, J.; Pang, P.K.T.; Ponglux, D.; Watanabe, K. Opioid receptor agonistic characteristics of mitragynine pseudoindoxyl in comparison with mitragynine derived from Thai medicinal plant Mitragyna speciosa. Gen. Pharmacol. 1999, 33, $73-81$. [CrossRef]

213. LaBryer, L.; Sharma, R.; Chaudhari, K.S.; Talsania, M.; Scofield, R.H. Kratom, an Emerging Drug of Abuse, Raises Prolactin and Causes Secondary Hypogonadism: Case Report. J. Investig. Med. High Impact Case Rep. 2018, 6. [CrossRef] [PubMed]

214. Matsumoto, K.; Horie, S.; Takayama, H.; Ishikawa, H.; Aimi, N.; Ponglux, D.; Murayama, T.; Watanabe, K. Antinociception, tolerance and withdrawal symptoms induced by 7-hydroxymitragynine, an alkaloid from the Thai medicinal herb Mitragyna speciosa. Life Sci. 2005, 78, 2-7. [CrossRef]

215. Trakulsrichai, S.; Sathirakul, K.; Auparakkitanon, S.; Krongvorakul, J.; Sueajai, J.; Noumjad, N.; Sukasem, C.; Wananukul, W. Pharmacokinetics of mitragynine in man. Drug Des. Devel. Ther. 2015, 9, 2421-2429. [CrossRef] 
216. Veltri, C.; Grundmann, O. Current perspectives on the impact of Kratom use. Subst. Abus. Rehabil. 2019, 10, 23-31. [CrossRef]

217. Fluyau, D.; Revadigar, N. Biochemical benefits, diagnosis, and clinical risks evaluation of kratom. Front. Psychiatry 2017, 8, 62. [CrossRef] [PubMed]

218. Liu, L.; Xu, F.-R.; Wang, Y.-Z. Traditional uses, chemical diversity and biological activities of Panax L. (Araliaceae): A review. J. Ethnopharmacol. 2020, 263, 112792. [CrossRef] [PubMed]

219. Won, H.J.; Kim, H., Il; Park, T.; Kim, H.; Jo, K.; Jeon, H.; Ha, S.J.; Hyun, J.M.; Jeong, A.; Kim, J.S.; et al. Non-clinical pharmacokinetic behavior of ginsenosides. J. Ginseng Res. 2019, 43, 354-360. [CrossRef] [PubMed]

220. Chen, W.; Balan, P.; Popovich, D.G. Chapter 6-Comparison of the ginsenoside composition of Asian ginseng (Panax ginseng) and American ginseng (Panax quinquefolius L.) and their transformation pathways. In Bioactive Natural Product, 1st ed.; Elsevier Inc.: Amsterdam, The Netherlands, 2019; Volume 63, pp. 161-195.

221. Leung, K.W.; Wong, A.S. Ginseng and male reproductive function. Spermatogenesis 2013, 3, e26391. [CrossRef]

222. Mancuso, C.; Santangelo, R. Panax ginseng and Panax quinquefolius: From pharmacology to toxicology. Food Chem. Toxicol. 2017, 107, 362-372. [CrossRef] [PubMed]

223. Ellis, J.M.; Reddy, P. Effects of Panax ginseng on quality of life. Ann. Pharmacother. 2002, 36, 375-379. [CrossRef]

224. Lee, S.-T.; Chu, K.; Sim, J.-J.; Heo, J.-H.; Kim, M. Panax ginseng enhances cognitive performance in Alzheimer disease. Alzheimer Dis. Assoc. Disord. 2008, 22, 222-226. [CrossRef] [PubMed]

225. Heo, J.-H.; Lee, S.-T.; Oh, M.J.; Park, H.-J.; Shim, J.-Y.; Chu, K.; Kim, M. Improvement of cognitive deficit in Alzheimer's disease patients by long term treatment with Korean red ginseng. J. Ginseng Res. 2011, 35, 457-461. [CrossRef] [PubMed]

226. Lee, N.-H.; Yoo, S.-R.; Kim, H.-G.; Cho, J.-H.; Son, C.G. Safety and tolerability of panax ginseng root extract: A randomized, placebo-controlled, clinical trial in healthy Korean volunteers. J. Altern. Complement. Med. 2012, 18, 1061-1069. [CrossRef] [PubMed]

227. Steiner, G.Z.; Yeung, A.; Liu, J.X.; Camfield, D.A.; de Blasio, F.M.; Pipingas, A.; Scholey, A.B.; Stough, C.; Chang, D.H. The effect of Sailuotong (SLT) on neurocognitive and cardiovascular function in healthy adults: A randomised, doubleblind, placebo controlled crossover pilot trial. BMC Complement. Altern. Med. 2016, 16, 15. [CrossRef]

228. Keshavan, M.; Jones, D.A.; Dube, S.; Grabowski, J.; Bell, J.; Sitaram, N. Cardioacceleratory responses to arecoline infusion during sleep in depressive, anxious, and normal subjects. Biol. Psychiatry 1987, 22, 1473-1477. [CrossRef]

229. Coon, J.T.; Ernst, E. Panax ginseng: A systematic review of adverse effects and drug interactions. Drug Saf. 2002, 25, 323-344. [CrossRef]

230. Woron, J.; Siwek, M. Unwanted effects of psychotropic drug interactions with medicinal products and diet supplements containing plant extracts. Psychiatr. Pol. 2018, 52, 983-996. [CrossRef] [PubMed]

231. Choi, M.K.; Song, I.S. Interactions of ginseng with therapeutic drugs. Arch. Pharm. Res. 2019, 42, 862-878. [CrossRef]

232. Liu, Y.; Yu, H.Y.; Xu, H.Z.; Liu, J.J.; Meng, X.G.; Zhou, M.; Ruan, H.L. Alkaloids with Immunosuppressive Activity from the Bark of Pausinystalia yohimbe. J. Nat. Prod. 2018, 81, 1841-1849. [CrossRef]

233. Sun, J.; Baker, A.; Chen, P. Profiling the indole alkaloids in yohimbe bark with ultra-performance liquid chromatography coupled with ion mobility quadrupole time-of-flight mass spectrometry. Rapid Commun. Mass Spectrom. 2011, 25, 2591-2602. [CrossRef]

234. Raman, V.; Avula, B.; Galal, A.M.; Wang, Y.H.; Khan, I.A. Microscopic and UPLC-UV-MS analyses of authentic and commercial yohimbe (Pausinystalia johimbe) bark samples. J. Nat. Med. 2013, 67, 42-50. [CrossRef] [PubMed]

235. Cohen, P.A.; Wang, Y.H.; Maller, G.; Desouza, R.; Khan, I.A. Pharmaceutical quantities of yohimbine found in dietary supplements in the USA. Drug Test. Anal. 2016, 8, 357-369. [CrossRef]

236. Uhde, T.W.; Boulenger, J.P.; Post, R.M.; Siever, L.J.; Vittone, B.J.; Jimerson, D.C.; Roy-Byrne, P.P. Fear and anxiety: Relationship to noradrenergic function. Psychopathology 1984, 17 (Suppl. 3), 8-23. [CrossRef] [PubMed] 
237. Cai, L.; Bakalli, H.; Rinaman, L. Yohimbine anxiogenesis in the elevated plus maze is disrupted by bilaterally disconnecting the bed nucleus of the stria terminalis from the central nucleus of the amygdala. Neuroscience 2012, 223, 200-208. [CrossRef] [PubMed]

238. Tam, S.W.; Worcel, M.; Wyllie, M. Yohimbine: A clinical review. Pharmacol. Ther. 2001, 91, 215-243. [CrossRef]

239. Owen, J.A.; Nakatsu, S.L.; Fenemore, J.; Condra, M.; Surridge, D.H.C.; Morales, A. The pharmacokinetics of yohimbine in man. Eur. J. Clin. Pharmacol. 1987, 32, 577-582. [CrossRef] [PubMed]

240. Berlan, M.; Le Verge, R.; Galitzky, J.; Le Corre, P. $\alpha$ 2-Adrenoceptor antagonist potencies of two hydroxylated metabolites of yohimbine. Br. J. Pharmacol. 1993, 108, 927-932. [CrossRef]

241. Kearney, T.; Tu, N.; Haller, C. Adverse drug events associated with yohimbine-containing products: A retrospective review of the California poison control system reported cases. Ann. Pharmacother. 2010, 44, 1022-1029. [CrossRef]

242. Shannon, M.; Neuman, M.I. Yohimbine. Pediatr. Emerg. Care 2000, 16, 49-50. [CrossRef] [PubMed]

243. Rothschild, A.J. New directions in the treatment of antidepressant-induced sexual dysfunction. Clin. Ther. 2000, 22, A42-A57. [CrossRef]

244. Shamloul, R. Natural aphrodisiacs. J. Sex. Med. 2010, 7, 39-49. [CrossRef] [PubMed]

245. West, E.; Krychman, M. Natural Aphrodisiacs-A Review of Selected Sexual Enhancers. Sex. Med. Rev. 2015, 3, 279-288. [CrossRef] [PubMed]

246. Cimolai, N.; Cimolai, T. Yohimbine use for physical enhancement and its potential toxicity. J. Diet. Suppl. 2011, 8, 346-354. [CrossRef]

247. Yang, H.L.; Yang, T.Y.; Gowrisankar, Y.V.; Liao, C.H.; Liao, J.W.; Huang, P.J.; Hseu, Y.C. Suppression of LPS-Induced Inflammation by Chalcone Flavokawain A through Activation of Nrf2/ARE-Mediated Antioxidant Genes and Inhibition of ROS/NF к B Signaling Pathways in Primary Splenocytes. Oxid. Med. Cell. Longev. 2020, 2020, 3476212. [CrossRef] [PubMed]

248. Baker, J.D. Pills, potions, products: Kava's transformations in new and nontraditional contexts. Contemp. Pac. 2012, 24, 233-265. [CrossRef]

249. Xuan, T.D.; Fukuta, M.; Wei, A.C.; Elzaawely, A.A.; Khanh, T.D.; Tawata, S. Efficacy of extracting solvents to chemical components of kava (Piper methysticum) roots. J. Nat. Med. 2008, 62, 188-194. [CrossRef] [PubMed]

250. Teschke, R.; Qiu, S.X.; Lebot, V. Herbal hepatotoxicity by kava: Update on pipermethystine, flavokavain B, and mould hepatotoxins as primarily assumed culprits. Dig. Liver Dis. 2011, 43, 676-681. [CrossRef]

251. Baum, S.S.; Hill, R.; Rommelspacher, H. Effect of kava extract and individual kavapyrones on neurotransmitter levels in the nucleus accumbens of rats. Prog. Neuropsychopharmacol. Biol. Psychiatry 1998, 22, 1105-1120. [CrossRef]

252. Boonen, G.; Ferger, B.; Kuschinsky, K.; Häberlein, H. In vivo effects of the kavapyrones (+)-dihydromethysticin and ( \pm -kavain on dopamine, 3,4-dihydroxyphenylacetic acid, serotonin and 5-hydroxyindoleacetic acid levels in striatal and cortical brain regions. Planta Med. 1998, 64, 507-510. [CrossRef] [PubMed]

253. Anke, J.; Ramzan, I. Pharmacokinetic and pharmacodynamic drug interactions with Kava (Piper methysticum Forst. f.). J. Ethnopharmacol. 2004, 93, 153-160. [CrossRef] [PubMed]

254. Mathews, J.M.; Etheridge, A.; Valentine, J.L.; Black, S.R.; Coleman, D.P.; Patel, P.; So, J.; Burka, L.T. Pharmacokinetics and disposition of the kavalactone kawain: Interaction with kava extract and kavalactones in vivo and in vitro. Drug Metab. Dispos. 2005, 33, 1555-1563. [CrossRef]

255. Fu, P.P.; Xia, Q.; Guo, L.; Yu, H.; Chan, P.C. Toxicity of kava kava. J. Environ. Sci. Health C Environ. Carcinog. Ecotoxicol. Rev. 2008, 26, 89-112. [CrossRef] [PubMed]

256. Clough, A.R.; Bailie, R.S.; Currie, B. Liver Function Test Abnormalities in Users of Aqueous Kava Extracts. J. Toxicol. Clin. Toxicol. 2003, 41, 821-829. [CrossRef]

257. White, C.M. The Pharmacology, Pharmacokinetics, Efficacy, and Adverse Events Associated With Kava. J. Clin. Pharmacol. 2018, 58, 1396-1405. [CrossRef] [PubMed]

258. de Vargas, F.S.; Almeida, P.D.O.; de Boleti, A.P.A.; Pereira, M.M.; de Souza, T.P.; de Vasconcellos, M.C.; Nunez, C.V.; Pohlit, A.M.; Lima, E.S. Antioxidant activity and peroxidase inhibition of Amazonian plants extracts traditionally used as anti-inflammatory. BMC Complement. Altern. Med. 2016, 16, 83. [CrossRef] [PubMed] 
259. Siqueira, I.R.; Fochesatto, C.; Da Silva, A.L.; Nunes, D.S.; Battastini, A.M.; Netto, C.A.; Elisabetsky, E. Ptychopetalum olacoides, a traditional Amazonian "nerve tonic", possesses anticholinesterase activity. Pharmacol. Biochem. Behav. 2003, 75, 645-650. [CrossRef]

260. Siqueira, I.R.; Lara, D.R.; Silva, D.; Gaieski, F.S.; Nunes, D.S.; Elisabetsky, E. Psychopharmacological properties of Ptycopetalum olacoides Bentham (Olacaceae). Pharm. Biol. 1998, 36, 327-334. [CrossRef]

261. Pankow, E.; Auterhoff, H. Contents of Muira puama. 2. Arch. Pharm. Ber. Dtsch. Pharm. Ges. 1969, 302, 209-212. [CrossRef]

262. Novello, C.R.; Marques, L.C.; Miyazaki, C.R.; Milaneze-Gutierre, M.A.; Carneiro-Torres, D.S.; Sarragiotto, M.H.; de Mello, J.C.P. Morphoanatomy and pharmacognostic study of the wood of Croton echioides, the Northeastern Marapuama. Braz. J. Pharmacogn. 2012, 22, 946-956. [CrossRef]

263. Vaz, Z.R.; Mata, L.V.; Calixto, J.B. Analgesic effect of the herbal medicine Catuama in thermal and chemical models of nociception in mice. Phyther. Res. 1997, 11, 101-106. [CrossRef]

264. Muszyńska, B.; Łojewski, M.; Rojowski, J.; Opoka, W.; Sułkowska-Ziaja, K. Natural products of relevance in the prevention and supportive treatment of depression. Psychiatr. Pol. 2015, 49, 435-453. [CrossRef] [PubMed]

265. Dimpfel, W.; Franklin, R.; Gericke, N.; Schombert, L. Effect of Zembrin ${ }^{\circledR}$ and four of its alkaloid constituents on electric excitability of the rat hippocampus. J. Ethnopharmacol. 2018, 223, 135-141. [CrossRef] [PubMed]

266. Manda, V.K.; Avula, B.; Ashfaq, M.K.; Abe, N.; Khan, I.A.; Khan, S.I. Quantification of mesembrine and mesembrenone in mouse plasma using UHPLC-QToF-MS: Application to a pharmacokinetic study. Biomed. Chromatogr. 2017, 31, e3815. [CrossRef]

267. Zhao, J.; Khan, I.A.; Combrinck, S.; Sandasi, M.; Chen, W.; Viljoen, A.M. ${ }^{1}$ H-NMR and UPLC-MS metabolomics: Functional tools for exploring chemotypic variation in Sceletium tortuosum from two provinces in South Africa. Phytochemistry 2018, 152, 191-203. [CrossRef]

268. Smith, M.T.; Crouch, N.R.; Gericke, N.; Hirst, M. Psychoactive constituents of the genus Sceletium N.E.Br. and other Mesembryanthemaceae: A review. J. Ethnopharmacol. 1996, 50, 119-130. [CrossRef]

269. Cashman, J.R.; Voelker, T.; Johnson, R.; Janowsky, A. Stereoselective inhibition of serotonin re-uptake and phosphodiesterase by dual inhibitors as potential agents for depression. Bioorg. Med. Chem. 2009, 17, 337-343. [CrossRef]

270. Loria, M.J.; Ali, Z.; Abe, N.; Sufka, K.J.; Khan, I.A. Effects of Sceletium tortuosum in rats. J. Ethnopharmacol. 2014, 155, 731-735. [CrossRef]

271. Harvey, A.L.; Young, L.C.; Viljoen, A.M.; Gericke, N.P. Pharmacological actions of the South African medicinal and functional food plant Sceletium tortuosum and its principal alkaloids. J. Ethnopharmacol. 2011, 137, 1124-1129. [CrossRef]

272. Smith, C. The effects of Sceletium tortuosum in an in vivo model of psychological stress. J. Ethnopharmacol. 2011, 133, 31-36. [CrossRef] [PubMed]

273. Carpenter, J.M.; Jourdan, M.K.; Fountain, E.M.; Ali, Z.; Abe, N.; Khan, I.A.; Sufka, K.J. The effects of Sceletium tortuosum (L.) N.E. Br. extract fraction in the chick anxiety-depression model. J. Ethnopharmacol. 2016, 193, 329-332. [CrossRef] [PubMed]

274. Stafford, G.I.; Pedersen, M.E.; van Staden, J.; Jäger, A.K. Review on plants with CNS-effects used in traditional South African medicine against mental diseases. J. Ethnopharmacol. 2008, 119, 513-537. [CrossRef]

275. Terburg, D.; Syal, S.; Rosenberger, L.A.; Heany, S.; Phillips, N.; Gericke, N.; Stein, D.J.; Van Honk, J. Acute effects of sceletium tortuosum (Zembrin), a dual 5-HT reuptake and PDE4 inhibitor, in the human amygdala and its connection to the hypothalamus. Neuropsychopharmacology 2013, 38, 2708-2716. [CrossRef]

276. Coetzee, D.D.; López, V.; Smith, C. High-mesembrine Sceletium extract (Trimesemine ${ }^{\mathrm{TM}}$ ) is a monoamine releasing agent, rather than only a selective serotonin reuptake inhibitor. J. Ethnopharmacol. 2016, 177, 111-116. [CrossRef] [PubMed]

277. Bennett, A.C.; Smith, C. Immunomodulatory effects of Sceletium tortuosum (Trimesemine ${ }^{\mathrm{TM}}$ ) elucidated in vitro: Implications for chronic disease. J. Ethnopharmacol. 2018, 214, 134-140. [CrossRef]

278. Krstenansky, J.L. Mesembrine alkaloids: Review of their occurrence, chemistry, and pharmacology. J. Ethnopharmacol. 2017, 195, 10-19. [CrossRef]

279. Beharry, S.; Heinrich, M. Is the hype around the reproductive health claims of maca (Lepidium meyenii Walp.) justified? J. Ethnopharmacol. 2018, 211, 126-170. [CrossRef]

280. Quandt, P.; Puga, M. Manic episode secondary to maca. Eur. Psychiatry 2016, 33, S339. [CrossRef] 
281. Ingawale, D.S.M.; Namdeo, A.G. Pharmacological evaluation of Ashwagandha highlighting its healthcare claims, safety, and toxicity aspects. J. Diet. Suppl. 2020, 1-44. [CrossRef]

282. Tandon, N.; Yadav, S.S. Safety and clinical effectiveness of Withania Somnifera (Linn.) Dunal root in human ailments. J. Ethnopharmacol. 2020, 255, 112768. [CrossRef] [PubMed]

283. Estrada-Reyes, R.; Carro-Juárez, M.; Martínez-Mota, L. Pro-sexual effects of Turnera diffusa Wild (Turneraceae) in male rats involves the nitric oxide pathway. J. Ethnopharmacol. 2013, 146, 164-172. [CrossRef] [PubMed]

284. María, D.-B.A.; María, V.V.R.; Lilian, M.-N.; Lucía, M.-M.; Oscar, G.-P.; Rosa, E.R. Neurobehavioral and toxicological effects of an aqueous extract of Turnera diffusa Willd (Turneraceae) in mice. J. Ethnopharmacol. 2019, 236, 50-62. [CrossRef] [PubMed]

285. Vilgiate, T. The Invention of Voacanga africana as a Ceremonial Psychedelic|Environment \& Society Portal. Available online: http://www.environmentandsociety.org/arcadia/invention-voacanga-africana-ceremonialpsychedelic (accessed on 27 August 2020).

286. Alper, K.R.; Lotsof, H.S.; Kaplan, C.D. The ibogaine medical subculture. J. Ethnopharmacol. 2008, 115, 9-24. [CrossRef]

287. Kombian, S.B.; Saleh, T.M.; Fiagbe, N.I.Y.; Chen, X.; Akabutu, J.J.; Buolamwini, J.K.; Pittman, Q.J. Ibogaine and a total alkaloidal extract of Voacanga africana modulate neuronal excitability and synaptic transmission in the rat parabrachial nucleus in vitro. Brain Res. Bull. 1997, 44, 603-610. [CrossRef]

288. Currais, A.; Chiruta, C.; Goujon-Svrzic, M.; Costa, G.; Santos, T.; Batista, M.T.; Paiva, J.; Do Céu Madureira, M.; Maher, P. Screening and identification of neuroprotective compounds relevant to Alzheimer's disease from medicinal plants of S. Tomé e Príncipe. J. Ethnopharmacol. 2014, 155, 830-840. [CrossRef]

289. Yuan, H.; Ma, Q.; Ye, L.; Piao, G. The traditional medicine and modern medicine from natural products. Molecules 2016, 21, 559. [CrossRef]

290. Ko, R.J. Adulterants in Asian patent medicines. N. Engl. J. Med. 1998, 339, 847. [CrossRef]

291. World Health Organization (WHO). WHO Traditional Medicine Strategy 2014-2023. Available online: https://apps.who.int/iris/bitstream/handle/10665/92455/9789241506090_eng.pdf;jsessionid= 55A97B8E89F5867AF5301067143BA683?sequence=1 (accessed on 27 August 2020).

Publisher's Note: MDPI stays neutral with regard to jurisdictional claims in published maps and institutional affiliations.

(C) 2020 by the authors. Licensee MDPI, Basel, Switzerland. This article is an open access article distributed under the terms and conditions of the Creative Commons Attribution (CC BY) license (http://creativecommons.org/licenses/by/4.0/). 